University of the District of Columbia School of Law

Digital Commons @ UDC Law

\title{
Expert Evidence in Gender-Based Asylum Cases: Cultural Translation for the Court
}

Lindsay M. Harris

Follow this and additional works at: https://digitalcommons.law.udc.edu/fac_journal_articles

Part of the Immigration Law Commons, and the International Humanitarian Law Commons 


\section{BENDER'S}

IMMIGRATION

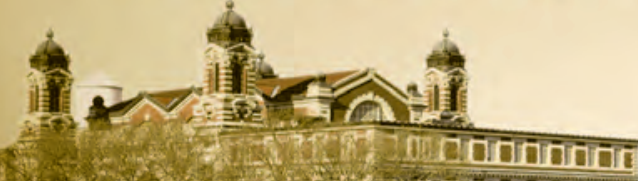

Vol. 17, No. 22 • November 15, 2012

Daniel M. Kowalski, Editor-in-Chief

\section{Inside This Issue}

Expert Evidence in Gender-Based Asylum Cases: Cultural Translation for the Court

LINDSAY M. HARRIS

IMMIGRATION NEWS

1809,1827

- U.S.-Russia Adoption Agreement

- Bits and Pieces (EOIR, U.S. Supreme Court)

CASE DIGESTS (details on next page) .1827

- Federal Court Decisions

- BIA Decisions

- AAO Decisions

GOVERNMENT DOCUMENTS

(details on next page).

APPENDICES

\section{U.S.-Russia Adoption Agreement}

The Department of State announced on October 16, 2012, that the Agreement between the United States of America and the Russian Federation Regarding Cooperation in Adoption of Children entered into force on November 1, 2012. This agreement should enhance the safeguards and protections for all parties involved in adoptions between the United States and the Russian Federation.

The Agreement's entry into force began a period of transition that will last six to nine months. Most cases already in progress as of November 1 will be able to continue under the old procedures.

The twenty-nine-page Agreement is at Appendix A and http://sgsandbox.his.com/adoptions/content/pdf/ usrussia_adoption_agmt-713\%2011-signed_english. pdf. A Frequently Asked Questions set (http://tsgsand box.his.com/adoptions/content/pdf/Russia_Bilateral_ Adoption_Agreement_FAQs1012.pdf) is reprinted at Appendix B. Further information on the Agreement is available at www.uscis.gov/adoption and www.adop tion.state.gov.

\section{BITS AND PIECES}

EOIR - In October the DOJ Office of the Inspector General issued an eighty-page report, number I-2013-01, available at http://www.justice.gov/oig/reports/2012/ e1301.pdf, indicating that "The OIG found that immigration court performance reports are incomplete and overstate the actual accomplishments of these courts. These flaws in EOIR's performance reporting preclude the Department from accurately assessing the courts' progress in processing immigration cases or identifying needed improvements." Juan Osuna, Executive Director

(News continued on page 1827)
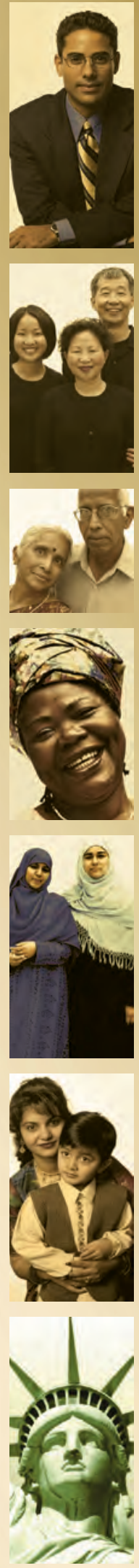


\section{EDITORIAL BOARD}

Valentine A. Brown

David L. Cleveland

Bruce A. Hake

Daniel C. Horne

María Pabón López

Stanley Mailman

Kathrin S. Mautino

Cyrus D. Mehta

Michael A. Olivas

Angelo Paparelli

Naomi Schorr

Margaret D. Stock

Alan Tafapolsky

A. James Vázquez-Azpiri

Ronald Wada

Stephen Yale-Loehr

\section{EDITORIAL STAFF}

Michael Bruno

Editorial Director

Ellen M. Flynn

Molly J. Liskow

Legal Editors,

Practice Area Content

Sue Asher Siler

Research Editor

The articles in this Bulletin represent the views of their authors and do not necessarily reflect the views of the Editorial Board

or Editorial Staff of this Bulletin or of LexisNexis Matthew Bender.

ISBN: 978-1-5791-1707-8 (eBook)

\section{CASE DIGESTS IN THIS ISSUE:}

Federal Court Decisions

- Ali v. Holder (asylum denial on merits)

- Borrome v. Att'y Gen. (conviction under FDCA not controlled-substance one)

- Matul-Hernandez v. Holder (social group)

- Dayo v. Holder (asylum denial on merits; breach of confidentiality)

- Liu v. Mund (affidavit of support beneficiary's duty to mitigate)

- Dandamudi v. Tisch (discrimination against noncitizen, non-LPR pharmacists)

- Mendoza v. U.S. (delayed filing for coram nobis)

- Pedersen v. Office of Personnel Mgmt. (DOMA)

BIA Decisions

Precedent:

- Matter of Sanchez-Herbert (termination of proceedings)

- Matter of Davey (meaning of "single offense" in personal-use exception)

AAO Decisions

- Matter of $X$ (extraordinary-ability I-140 for M.I.T. professor-scientist)

- Matter of $X$ (extraordinary-ability I-140 for software engineer)

- Matter of $X$ (extraordinary-ability I-140 for educator-activist)

- Matter of X (MTR procedural failures)

- Matter of $X$ (untimely appeal from extraordinary-ability I-140 denial)

\section{GOVERNMENT DOCUMENTS IN THIS ISSUE:}

Federal Register

- DHS; designation of Taiwan for Visa Waiver Program; final rule

- DOS; repeal of 22 C.F.R. Pt. 52, on consular role in marriages; final rule

- Treasury; OFAC: renaming of Iranian Transactions Regulations; final rule

ICE Memorandum 1834

- October 24, 2011, John Morton directive on enforcement actions involving sensitive locations

USCIS Documents

- USCIS-AILA Meeting Oct. 9, 2012, minutes

- USCIS Field Ops-AILA Meeting Oct. 4, 2012, minutes

DOL Guidance

- TEGL No. 9-12, Human Trafficking: Services and Referrals (Oct. 24, 2012)

DOS Cable

- October 12, 2012, cable on B-1 in Lieu of H-1B or H-3 visa

ON THE COVER: Masthead artwork of Ellis Island, New York Harbor, New York

A NOTE ON CITATION: The correct citation form for this publication is: 17 Bender's Immigr. Bull. 1811 (Nov. 15, 2012).

This publication is designed to provide accurate and authoritative information in regard to the subject matter covered. It is provided with the understanding that the publisher is not engaged in rendering legal, accounting, or other professional service. If legal or other expert assistance is required, the services of a competent professional should be sought.

From the Declaration of Principles jointly adopted by a Committee of the American Bar Association and a Committee of Publishers and Associations.

\section{(O" LexisNexis" \\ Matthew Bender ${ }^{\oplus}$}

Copyright (C) 2012 LexisNexis and the Knowledge Burst logo are registered trademarks and Michie is a trademark of Reed Elsevier Properties Inc., used under license. Matthew Bender and the Matthew Bender Flame Design are registered trademarks of Matthew Bender Properties Inc. 


\title{
Expert Evidence in Gender-Based Asylum Cases: Cultural Translation for the Court
}

\author{
by Lindsay M. HARris, EsQ.
}

This article examines the use of country conditions experts in gender-based asylum claims, with a focus on African women and girls facing gender-based violence in their countries of origin. Using anonymous case examples from the work of the Tahirih Justice Center's African Women's Empowerment Project, the article explores the role of experts and the critical bridge that experts can provide in asylum claims adjudicated at the asylum office and in immigration court. A brief overview of U.S. asylum law and procedures sets the stage for a deeper look at expert evidence.

In the context of gender-based asylum claims, experts often play a pivotal role in explaining gender-based violence by providing information and opinions on the political, social, cultural, familial, and economic contexts for this violence. That country conditions experts add a great deal to an asylum claim is nothing new, but this issue has taken on even more critical importance with the evolution of the law around "particular social group" and the introduction of the concepts of social visibility and particularity. This article addresses the role of experts in: (a) explaining conditions on the ground in the country of origin and corroborating an applicant's asylum claim; (b) providing evidence to establish that persecution was "on account of" one of the five statutory grounds for persecution (race, religion, nationality, political opinion, or membership in a particular social group); (c) examining situations in which non-state actors act as persecutors and in explaining government unwillingness or inability to protect an applicant from persecution; (d) assessing the legal structure of the country in question and how that legal structure intersects with the reality of attitudes toward certain groups or cultural practices. The article concludes with practice pointers for both attorneys and potential expert witnesses in working together to present gender-based asylum claims in the United States.

\section{INTRODUCTION}

\section{a. Overview of U.S. Asylum Law}

Individuals seeking asylum in the United States must meet the refugee definition codified at 8 U.S.C. $\S 1101(\mathrm{a})(42)$ (Immigration and Nationality Act ("INA") §101(a)(42)), which reads in part: any person who is outside any country of such person's nationality or, in the case of a person having no nationality, is outside any country in which such person last habitually resided, and who is unable or unwilling to return to, and is unable or unwilling to avail himself or herself of the protection of, that country because of persecution or a well-founded fear of persecution on account of race, religion, nationality, membership in a particular social group, or political opinion.

An asylum applicant may have suffered persecution in the past, ${ }^{1}$ or may face a well founded fear of persecution in the future. U.S. courts have interpreted persecution to include: threats of harm or death; ${ }^{2}$ detention; ${ }^{3}$ rape $;^{4}$

1 Asylum may be granted solely based on past persecution where a future fear does not exist or has been rebutted. This is often known as "humanitarian asylum," and under the regulations may be granted due to "compelling reasons" arising out of the severity of the past persecution or because of a "reasonable possibility that he or she may suffer other serious harm" upon removal. 8 C.F.R. §1208.13(b)(1)(iii); see also Matter of L-S-, 25 I. \& N. Dec. 705 (BIA 2012) (remanding to the immigration judge ("IJ") to determine whether the Albanian asylum applicant faced other serious harm upon return); Matter of S-A-K-, 24 I. \& N. Dec. 464 (BIA 2008) (granting asylum to a Somali mother and daughter based on the severity of the past persecution in the form of being subjected to FGM multiple times); Matter of Chen, 20 I. \& N. Dec. 16, 20-21 (BIA 1989) (granting asylum to a respondent who suffered severe past persecution in China and demonstrated other compelling factors to warrant a favorable exercise of discretion).

2 Crespin-Valladares v. Holder, 632 F.3d 117, 126 (4th Cir. 2011) (finding that death threats may constitute persecution (citing Li v. Gonzalez, 405 F.3d 171, 177 (4th Cir. 2005))); Un v. Gonzales, 415 F.3d 205, 210 (1st Cir. 2005) (finding that verbal death threats may amount to persecution); Baballah $\mathrm{v}$. Ashcroft, 367 F.3d 1067, 1074 (9th Cir. 2004) (finding that threats even where the applicant has not been beaten or physically harmed can amount to persecution); Chang v. INS, 119 F.3d 1055, 1066 (3d Cir. 1997) (finding that threats to life, confinement, and torture constitute persecution).

3 Phommasoukha v. Gonzales, 408 F.3d 1011, 1015 (8th Cir. 2005); Matter of Toboso-Alfonso, 20 I. \& N. Dec. 819, 823 (BIA 1990).

${ }^{4}$ Shoafera v. INS, 228 F.3d 1070, 1074 (9th Cir. 2000); Matter of D-V-, 21 I. \& N. Dec. 77, 79-80 (BIA 1993). 
severe economic deprivation; ${ }^{5}$ lack of reproductive control; ${ }^{6}$ physical abuse, ${ }^{7}$ including domestic violence ${ }^{8}$ and female genital mutilation ("FGM"); ${ }^{9}$ forced labor, ${ }^{10}$ verbal, emotional, or psychological abuse; ${ }^{11}$ or deprivation of education. ${ }^{12}$ Courts will also consider a cumulative analysis of all discriminatory acts to which an individual has been subjected. ${ }^{13}$

An applicant's future fear of persecution must be subjective, which can be established by the applicant's credible testimony, and objective, meaning that a reasonable person in the applicant's circumstances would also fear persecution. ${ }^{14}$ A successful asylum applicant must prove a reasonable possibility of future persecution, which may be as low as a one in ten chance of future persecution. ${ }^{15}$

\footnotetext{
${ }^{5}$ Matter of T-Z-, 24 I. \& N. Dec. 163, 170-71 (BIA 2007).

${ }^{6}$ Wang v. Ashcroft, 341 F.3d 1015, 1020 (9th Cir. 2003); Matter of Y-T-L-, 23 I. \& N. Dec. 601, 603 (BIA 2003).

${ }^{7}$ Chen v. INS, 359 F.3d 121, 128 (2d Cir. 2004).

8 There is no precedent decision to cite for the proposi-
} tion that harm in the form of domestic violence constitutes persecution. Domestic violence often encompasses other recognized forms of persecution, such as rape and other physical harm. The Department of Homeland Security briefs filed in Matter of $R$ - $A$ - and Matter of $L-R$ - are instructive as to the government's position on asylum claims based on domestic violence. These briefs are available at http://cgrs. uchastings.edu/campaigns/alvarado.php and http://cgrs. uchastings.edu/campaigns/Matter\%20of\%20LR.php. 1996)

${ }^{9}$ Matter of Kasinga, 21 I. \& N. Dec. 357, 365 (BIA

${ }^{10}$ Lhanzom v. Gonzales, 430 F.3d 833, 847-49 (7th Cir. 2005)

11 Javhlan v. Holder, 626 F.3d 1119, 1122-23 (9th Cir. 2010); Shoaira v. Ashcroft, 377 F.3d 837, 844 (8th Cir. 2004).

12 Matter of S-A-, 22 I. \& N. Dec. 1328, 1335 (BIA 2000).

13 See, e.g., Baharon v. Holder, 588 F.3d 228, 232 (4th Cir. 2009); Korablina v. INS, 158 F.3d 1038, 1044 (9th Cir. 1998); Matter of O-Z-, 22 I. \& N. Dec. 23, 26 (BIA 1998).

14 See, e.g., Li v. Gonzales, 405 F.3d 171, 176 (4th Cir. 2005) (a "reasonable person in like circumstances would fear persecution").

15 INS v. Cardoza-Fonseca, 480 U.S. 421, 431 (1987). An application for asylum is also an application for withholding of removal under INA $\S 241(b)(3), 8$ U.S.C. $\S 1231(\mathrm{~b})(3)$. The Supreme Court has stated that the burden of proof for withholding is higher than for asylum - withholding requires that an applicant face a threat to his or her life or freedom that is "more likely than not," meaning a higher than $50 \%$ chance of such harm. INS v. Stevic, 467 U.S. 407, 424 (1984)
Perhaps the most important aspect of the refugee definition for the purposes of this paper is the requirement that the past or future persecution was or will be "on account of" one of the five protected grounds - the individual's race, religion, nationality, membership in a particular social group, or political opinion. This “on account of" requirement is also referred to as nexus to a statutory ground. Asylum applicants are required to put forth direct or circumstantial evidence that their persecutor was or is motivated to harm them by one of the five grounds for asylum. ${ }^{16}$

It is quite straightforward to imagine the type of case where someone is persecuted on account of his or her race or religion, or even his or her nationality, which is often construed broadly to include ethnicity and not only citizenship. Persecution on account of one's political opinion is also well within the realm of our collective imagination - indeed, the quintessential refugee is the political dissident, perhaps an outspoken opposition party member whom a government seeks to silence. For this reason, asylum in general is sometimes referred to as "political asylum."

Persecution on account of membership in a particular social group, however, takes us into murkier waters, but it is here that we must dive in. A particular social group must be united by a "common immutable characteristic," one that the group members either cannot change or should not be required to change because it is so fundamental to individual identity or conscience. ${ }^{17}$ Common immutable characteristics can include, for example, gender or sex, ${ }^{18}$ sexual orientation, ${ }^{19}$ or kinship or family ties. ${ }^{20}$

Additional factors to include in the particular social group analysis, introduced by the Board of

16 INS v. Elias-Zacarias, 502 U.S. 478 (1992). The passage of the REAL ID Act in 2005 clarified that the asylum applicant must show that the statutory ground was "one central reason" for the persecution. The BIA has interpreted this as meaning that the statutory ground "cannot be incidental, tangential, superficial, or subordinate to another reason for harm." Matter of J-B-N-, 24 I. \& N. Dec. 208, 214 (BIA 2007).

17 Matter of Acosta, 19 I. \& N. Dec. 211, 233 (BIA 1985).

18 Matter of Kasinga, 21 I. \& N. Dec. 357, 366 (BIA 1996); see also Matter of Acosta, 19 I. \& N. Dec at 233.

19 Matter of Toboso-Alfonso, 20 I. \& N. Dec. 819, 822-23 (BIA 1990).

${ }^{20}$ See, e.g., Crespin-Valladares v. Holder, 632 F.3d 117, 124-26 (4th Cir. 2011) (holding that "family members of those who actively oppose gangs in El Salvador by agreeing to be prosecutorial witnesses" was a cognizable social group); Matter of Acosta, 19 I. \& N. Dec. at 233. 
Immigration Appeals ("BIA") in 2006 and 2007, are social visibility ${ }^{21}$ and particularity. ${ }^{22}$ Social visibility, although a confusing term, is properly understood as the requirement that society in the country in question perceives that particular social group as a group. ${ }^{23}$ Particularity requires that the proposed group can accurately be described in a manner sufficiently distinct that it would be recognized, in the society in question, as comprising a discrete class of persons." 24 The introduction of these two relatively recent concepts, social visibility and particularity, has made the use of experts as cultural translators for adjudicators in asylum cases more critical than ever before.

\section{b. Overview of U.S. Asylum Procedures}

The U.S. asylum system divides asylum applications into two basic tracks, affirmative and defensive asylum.

\section{Affirmative Asylum}

First, an applicant may proactively file what is known as an "affirmative" application for asylum. The applicant sends in the application for asylum (on Form I-589) to the United States Citizenship and Immigration Services, within the Department of Homeland Security ("DHS"), and receives an interview conducted

\footnotetext{
${ }^{21}$ Matter of C-A-, 23 I. \& N. Dec. 951, 960 (BIA 2006).

22 Matter of S-E-G-, 24 I. \& N. Dec. 579, 582-86 (BIA 2008); Matter of A-M-E-, 24 I. \& N. Dec. 69, 76 (BIA 2007).

23 This concept is undoubtedly confusing, and some
} appellate courts have found that the BIA's own understanding and use of the notion of social visibility has been so inconsistent that the courts have refused to accord deference to the BIA's approach of using social visibility. See, e.g., Valdiviezo-Galdamez v. Att'y Gen. of the United States, 663 F.3d 582, 603-08 (3d Cir. 2011) (refusing to accord Chevron deference to the concepts of both social visibility and particularity); Benitez-Ramos v. Holder, 589 F.3d 426, 430-31 (7th Cir. 2009) (declining to accord Chevron deference to the BIA's use of social visibility because the BIA used the term inconsistently and did not seem to understand the concept); Gatimi v. Holder, 578 F.3d 611, 615-16 (7th Cir. 2009) (rejecting the use of social visibility); see also Henriquez-Rivas v. Holder, 670 F.3d 1033 (9th Cir. 2012) (order granting rehearing en banc for a Salvadoran petitioner who had testified against gangs and feared persecution on account of her particular social group; in his concurrence in the original memorandum disposition denying her petition for review, Judge Bea had suggested that the Ninth Circuit revisit the concept of social visibility).

${ }^{24}$ Matter of S-E-G-, 24 I. \& N. Dec. at 584. by staff of one of eight asylum offices nationwide. ${ }^{25}$ The asylum interview is a non-adversarial process whereby an asylum officer interviews the applicant to assess his or her claim. ${ }^{26}$ Many individuals go through the asylum process unrepresented by counsel; however, research confirms that representation greatly increases an individual's likelihood of success. ${ }^{27}$

At the asylum interview, in addition to the I-589 form, an applicant should submit documents to support his or her claim, including but not limited to documentation to establish identity, a detailed declaration of the applicant's past persecution or future fear, a letter brief drafted by an attorney establishing how the claim meets the refugee definition, supporting letters or witness statements from friends, family, or other individuals, and expert reports. These expert reports may include a medical examination conducted by a doctor, a psychological examination conducted by a psychological professional, ${ }^{28}$ or what is colloquially known as an affidavit from a "country conditions expert." The country conditions expert is the focus of this paper.

25 There are eight asylum offices (Arlington, VA; Chicago, IL; Houston, TX; Los Angeles, CA; Miami, FL; Newark, NJ; New York City, NY; and San Francisco, CA), and each of these offices also has asylum officers "ride circuit," meaning that they travel to certain other locations to hear asylum cases. For example, Newark Asylum Office (ZNK) staffers handle cases in Boston, Massachusetts, and Buffalo, New York; Chicago Asylum Office staffers (ZCH) interview in Helena, Montana; Arlington Asylum Office's (ZAR) circuit ride to Atlanta, Georgia; and Miami Asylum Office (ZMI) staffers interview in Jacksonville, Florida, San Juan, Puerto Rico, and St. Thomas, Virgin Islands.

${ }^{26}$ See 8 C.F.R. § 208.9.

27 Jaya Ramji-Nogales et al., Refugee Roulette: Disparities in Asylum Adjudication, 60 Stan. L. Rev. 295, 340 (2007) ("Represented asylum seekers were granted asylum at a rate of $45.6 \%$, almost three times as high as the $16.3 \%$ grant rate for those without legal counsel."); TRAC Immigration, Asylum Denial Rate Reaches All Time Low: FY 2010 Results, a Twenty-Five Year Perspective (Sept. 2, 2010), available at http://trac.syr.edu/immigration/reports/240 ("During FY 2010, for example, only 11 percent of those without legal representation [in immigration court] were granted asylum; with legal representation the odds rose to 54 percent.").

28 Note that this paper does not address the role of psychological and medical experts. The fact that these types of experts are not analyzed in this paper in no way reflects their importance in the process. Indeed, these experts can provide critical information that can make or break any asylum case, including gender-related claims. 
For the country conditions expert, writing to support an asylum claim at the asylum office level requires only a written affidavit and no possibility of live testimony. ${ }^{29}$ After an asylum interview, the asylum officer generally makes one of two decisions ${ }^{30}$ - to grant asylum or to refer the applicant to immigration court for de novo review. Thus, by filing an unsuccessful affirmative asylum application, an individual can receive a Notice to Appear ("NTA") in immigration court to face the task of re-presenting her claim for asylum and the risk of being ordered removed from the United States if her claim is unsuccessful there. $^{31}$

\section{Defensive Asylum}

An asylum seeker will be in defensive proceedings, then, if her affirmative asylum claim is not successful. An individual may also present asylum claims in immigration court for the first time if he or she is issued an NTA for immigration court. DHS, through either of its enforcement agencies, Immigration and Customs Enforcement ("ICE") or Customs and Border Protection, may issue an NTA following the expiration of an individual's lawful status in the United States or, at any point, including upon entry into the United

29 Refugee, Asylum and International Operations Directorate, Asylum Division, Affirmative Asylum Procedures Manual 26 (Nov. 2007, rev. July 2010), available at http:// www.uscis.gov/USCIS/Humanitarian/Refugees $\% 20 \& \% 20 \mathrm{~A}$ sylum/Asylum/2007_AAPM.pdf (last visited Oct. 22, 2012) and www.lexis.com $>$ Immigration $>$ Find Administrative Materials > Immigration Law \& Procedure-Agency Manuals; see also 8 C.F.R. § 208.9.

30 If the applicant is in status, meaning that he or she has a valid visa at the time of filing for asylum, the officer may also issue a "Notice of Intent to Deny," allowing the applicant a certain amount of time (sixteen days, if the NOID and response go by mail) to respond to this notice. Affirmative Asylum Procedures Manual 44. The asylum office could then issue a final denial of asylum, but would not refer the individual to immigration court for removal proceedings, because the individual still has lawful status in the United States.

31 Review by the immigration court is only the first "appeal" in the process. An unsuccessful asylum applicant in immigration court may file an appeal with the nation's highest immigration tribunal, the Board of Immigration Appeals. If the BIA agrees with the immigration court's decision, the asylum applicant may appeal to one of the eleven federal courts of appeals (according to the state of residence) and then finally petition for certiorari from the United States Supreme Court.
States, where the agencies notice that the individual is present without status and decide to initiate proceedings. $^{32}$

Defensive asylum proceedings are far more complex than affirmative asylum proceedings. The immigration courts, as administrative tribunals under the Executive Office of Immigration Review within the Department of Justice, generally require the presentation of live testimony from the applicant and any witnesses, including direct and cross-examination of those individuals. It is in this context that a country conditions expert is most likely to provide live or telephonic testimony in court in addition to supplying a written affidavit. Asylum proceedings in immigration court are adversarial, meaning that the applicant's attorney argues in favor of asylum, while opposing trial attorneys from ICE's regional Office of Chief Counsel may argue against granting relief. An indepth discussion on preparation of experts to testify in immigration court is included below, under "Practical Tips."

\section{c. Brief Overview of Gender-Based Asylum}

Country conditions experts are particularly important in gender-based asylum cases as cultural translators for the court. To understand gender-based asylum claims, we must first have an understanding of "gender." In this context, gender means the societal roles associated with men and women, while sex

\footnotetext{
32 The decision whether to initiate proceedings is discretionary, and an individual may come to the attention of the authorities without proceedings ever being initiated. Although prosecutorial discretion is nothing new, a 2011 memo issued by ICE Chief John Morton gave detailed guidance on factors to consider in exercising prosecutorial discretion. See Memorandum from John Morton, Director of U.S. Immigration and Customs Enforcement, to All Field Office Directors, Special Agents in Charge, and Chief Counsel, Exercising Prosecutorial Discretion Consistent with the Civil Immigration Enforcement Priorities of the Agency for the Apprehension, Detention, and Removal of Aliens (June 17, 2011), reprinted at 16 Bender's Immigr. Bull. 1236 (App. C) (July 15, 2011), available at http://www.ice.gov/doclib/secure-communities/ pdf/prosecutorial-discretion-memo.pdf; see also Shoba Sivaprasad Wadhia, Prosecutorial Discretion in Immigration Agencies: A Year in Review, 2012 Emerging Issues 6173; Shoba Sivaprasad Wadhia, Reflections on Prosecutorial Discretion One Year After the Morton Memo, 2012 Emerging Issues 6417 (on www.lexis.com). This memo led to the institution of pilot prosecutorial discretion projects in the Baltimore and Denver immigration courts in an effort to address the backlog of cases in immigration courts. See Review of All Removal Cases, 16 Bender's Immigr. Bull. 1887 (Dec. 15, 2011).
} 
refers to the biological determinant of "male" versus "female." 33 The term "gender-related asylum" generally refers to cases involving either persecution against a woman because of her gender or failure to conform to gender norms (gender-related harm), ${ }^{34}$ or persecution that takes the form of gender-specific harm. Gender-specific harm is persecution unique to, or disproportionately inflicted on, women (including, for example, FGM, domestic violence, rape, forced marriage, breast ironing, and widow rituals) regardless of the reason for infliction. Cases may involve both gender-specific harm and gender-related harm-i.e., a woman is subject to a gender-specific harm such as rape or FGM because of her gender. As mentioned above, the United States has recognized gender-specific harms as persecution, including rape, ${ }^{35}$ domestic violence, and FGM. ${ }^{36}$ One of the main issues in gender-related cases, then, involves establishing that the persecution suffered or feared was or will be imposed because of a nexus to one of the five statutorily protected grounds - race, religion, nationality, membership in a particular social group, or political opinion.

Gender-related cases may be tied to religious views. In Matter of $S-A-$, the BIA found that a Moroccan father persecuted his daughter on account of her religious views because she subscribed to a more liberal version of Islam than her father and differed in her beliefs on the role of women in society. ${ }^{37}$ Genderrelated claims may be tied to persecution on account of political opinion. This may be where a woman's

33 Heaven Crawley, Refugees and Gender: Law and Process 7 (2001). It is important to note that even biologically determined gender categories are fluid and individuals who do not fit neatly into the "male" or "female" box may also face persecution and can access asylum protection because they have suffered or fear harm.

34 Note that gender-related harm encompasses harm against someone based on his or her sexual orientation or identity - which can be seen as a failure to conform to expected gender norms in various cultural contexts.

35 Matter of D-V-, 21 I. \& N. Dec. 77, 79-80 (BIA 1993).

36 Matter of Kasinga, 21 I. \& N. Dec. 357, 366 (BIA 1996).

${ }^{37}$ Matter of S-A-, 22 I. \& N. Dec. 1328, 1336 (BIA 2000) political opinion is, for example, a belief in women's rights or equality, feminism, or a woman's right to control her own body. ${ }^{38}$

Often, however, gender-related asylum claims fall under the particular-social-group ground for asylum. It is possible and furthermore advised for attorneys to articulate all possible grounds for which a woman qualifies for asylum where persecution is inflicted or feared on account of more than one ground for asylum. As discussed above, current particular-social-group jurisprudence requires that a particular social group be unified by a common, immutable characteristic. Gender or sex has been recognized as a common, immutable characteristic that an individual either cannot change or should not be required to change. ${ }^{39}$

More recently, as discussed above, the BIA introduced other factors for consideration in social group formulation, specifically "social visibility" and "particularity." As a result, defining social group is much more challenging and the role of country conditions experts increasingly important. Social visibility requires the attorney to articulate how the particular social group is actually perceived by society in the country in question as a group. Particularity requires the attorney to articulate how the particular social group is not amorphous, but is sufficiently well defined that society members could tell who was within and who was outside the social group. ${ }^{40}$ Experts on a particular country or culture can be instrumental in helping advocates and adjudicators in

38 See Saldarriaga v. Gonzalez, 402 F.3d 461, 466 (4th Cir. 2005) (recognizing that "[1]ess overtly symbolic acts may also reflect a political opinion"); Fatin v. INS, 12 F.3d 1233, 1242 (3d Cir. 1993) (finding that there is "little doubt that feminism qualifies as a political opinion within the meaning of the relevant statutes"); Lazo-Majano v. INS, 813 F.2d 1432, 1435 (9th Cir. 1987) (finding that the applicant was persecuted on account of her opposition to the "political opinion that a man has a right to dominate" as demonstrated by her fleeing her persecutor); see also Abdel-Rahman v. Gonzales, 493 F.3d 444, 450-51 (4th Cir. 2007) (holding that an asylum applicant's political opinion may be imputed to him by the persecutor at least partially because of ties to his wife).

39 Matter of Acosta, 19 I. \& N. Dec 211, 233 (BIA 1985).

40 As discussed above, supra note 23, two circuit courts have rejected the notion of social visibility and the Third Circuit has also rejected particularity. 
understanding how certain groups may or may not be socially visible and particular.

\section{d. Experts in Asylum Proceedings in General}

In 2005, Interpreter Releases published a helpful overview of the use of experts in defensive asylum proceedings. ${ }^{41}$ This paper expands on that article and provides an update on recent case law regarding the use of experts. Judicial opinions published since 2005 addressing the use of experts guide the Practical Tips section below. Notably, the Immigration Court Practice Manual, first published in February 2008, does not provide any specific guidance on the use of experts in immigration proceedings, other than to require experts to be properly listed as witnesses prior to the hearing. ${ }^{42}$ This paper considers the use of experts for both affirmative and defensive asylum proceedings.

Immigration courts are not governed by the Federal Rules of Evidence ("FRE"). Indeed, the evidentiary requirements that govern federal courts are relaxed in immigration court. ${ }^{43}$ Nonetheless, the FRE can serve as guidance

41 See Rachael Keast, Using Experts for Asylum Cases in Immigration Court, 82 Interpreter Releases 1237 (Aug. 1, 2005). Also instructive is BIA Member and former IJ Garry Malphrus's piece Expert Witnesses in Immigration Proceedings, published in the May 2010 issue of the Executive Office of Immigration Review's Immigration Law Advisor (Vol. 4, No. 5), available at http://www.justice.gov/eoir/vll/ILANewsleter/ILA\%202010/vol4no5.pdf.

42 See Office of the Chief Immigration Judge, Immigration Court Practice Manual § 3.3(g) (2008), available at http:// www.justice.gov/eoir/vll/OCIJPracManual/ocij_page1.htm and www.lexis.com $>$ Immigration $>$ Find Administrative Materials $>$ Immigration Law \& Procedure - Agency Manuals (requiring experts to be listed as witnesses and a curriculum vitae or résumé to be attached to the witness list).

43 See Matter of Devera, 16 I. \& N. Dec. 266, 268-69 (BIA 1977); see also Matter of V-K-, 24 I. \& N. Dec. 500, 502 n. 2 (BIA 2008) (stating that expert evidence can be accepted to help to satisfy a party's burdens of proof and persuasion). in determining the rules regarding expert testimony in immigration court. Most instructive are FRE $702^{44}$ and $703,{ }^{45}$ on testimony of experts and the bases of an expert's testimony. Expert opinions or testimony in immigration court may be based on hearsay evidence. ${ }^{46}$ The BIA has recognized the probative value of expert testimony in immigration court because "Immigration Judges, like other trial judges generally, are often required to determine factual disputes regarding matters on which they possess little or no knowledge or substantive expertise, and, in making such determinations, they typically rely on evidence, including expert testimony, presented by the parties." 47

Individuals who are experts on a particular culture, region, or country are often referred to as "country conditions experts." No guidelines or rules govern

44 FRE 702 states:

Testimony by Expert Witnesses[:] A witness who is qualified as an expert by knowledge, skill, experience, training, or education may testify in the form of an opinion or otherwise if:

(a) the expert's scientific, technical, or other specialized knowledge will help the trier of fact to understand the evidence or to determine a fact in issue;

(b) the testimony is based upon sufficient facts or data;

(c) the testimony is the product of reliable principles and methods; and

(d) the expert has reliably applied the principles and methods to the facts of the case.

45 FRE 703 states:

Bases of an Expert's Opinion Testimony[:] An expert may base an opinion on facts or data in the case that the expert has been made aware of or personally observed. If experts in the particular field would reasonably rely on those kinds of facts or data in forming an opinion on the subject, they need not be admissible for the opinion to be admitted. But if the facts or data would otherwise be inadmissible, the proponent of the opinion may disclose them to the jury only if their probative value in helping the jury evaluate the opinion substantially outweighs their prejudicial effect.

46 Aguilar-Ramos v. Holder, 594 F.3d 701, 706 n.7 (9th Cir. 2010) ("An expert is permitted to base his opinion on hearsay evidence and need not have personal knowledge of the facts underlying his opinion.").

47 Matter of Marcal Neto, 25 I. \& N. Dec. 169, 176 (BIA 2010) (emphasis added). 
how much time, if any, an expert must have spent within a culture or country or whether that time spent must be recent. ${ }^{48}$ Similarly, an expert need not have published academic articles or books on the subject matter of his or her testimony. Further, no requirement exists as to the expert's level of education, although many experts commonly retained for asylum proceedings hold doctoral degrees.

\section{CULTURAL TRANSLATORS FOR THE COURT: THE ROLE OF EXPERTS IN GENDER-BASED ASYLUM CASES}

This section will highlight some of the key issues in gender-based asylum cases that collaboration with a country conditions expert can help to address.

\section{a. Explaining Cultural Issues that May Affect Credibility}

An expert who is well versed in a specific culture may be able to assist a decisionmaker in assessing credibility. Credibility is a key issue in the adjudication of asylum claims. ${ }^{49}$ Indeed, because the circumstances of sudden or unanticipated flight from a country may mean that an individual has little documentary evidence to support her claim, cases often hinge on the testimony of the individual him- or herself. ${ }^{50}$ That testimony must, above all, be credible. Of course, credibility is in the eye of the adjudicator, and the adjudicator comes to each case not as a blank slate, but as a human being with his or her own cultural experiences, biases, expectations, and perspective. The decision that an IJ

48 See Koval v. Gonzales, 418 F.3d 798, 808-09 (7th Cir. 2005) (finding that IJ erred in excluding expert testimony where expert had not been to the country in question in twelve years).

49 Under section 101(a)(3) of the REAL ID Act of 2005, Div. B of Pub. L. No. 109-13, 119 Stat. 302, 303 (codified at INA $\S 208(b)(1)(B)(i i i), 8$ U.S.C. $§ 1158(b)(1)(B)($ iii)), a trier of fact may, considering the totality of the circumstances, base a credibility finding on an asylum applicant's demeanor, the plausibility of his account, and inconsistencies in statements, without regard to whether they go to the heart of the asylum claim.

50 See 8 C.F.R. $\$ 208.13$ ("testimony of the applicant, if credible, may be sufficient to sustain the burden of proof without corroboration"). But see Matter of S-M-J-, 21 I. \& N. Dec. 722 (BIA 1997) (corroborating evidence should be submitted where reasonably available, or an explanation should be made as to why it was not submitted); Matter of J-Y-C-, 24 I. \& N. Dec. 260 (BIA 2007) (under the REAL ID Act an IJ may, considering the totality of the circumstances, base a credibility finding on an asylum applicant's demeanor, the plausibility of his account, and inconsistencies in statements, without regard to whether they go to the heart of the asylum claim). makes regarding credibility is accorded a high level of deference on appeal, ${ }^{51}$ and thus attorneys should focus on ensuring that any potential credibility concerns for their client's case are adequately addressed.

The U.S. Gender Guidelines, issued in 1995, explain that an adjudicator should understand when assessing demeanor and credibility that an individual who has suffered trauma may appear "numb or show emotional passivity [or] may give matter-of-fact recitations of serious instances of mistreatment." ${ }^{, 52}$ Further, trauma may cause damaged or distorted memories and may block an individual from recounting certain events. ${ }^{53}$ The Guidelines also specify that a lack of eye contact or averting one's gaze may be culturally influenced. $^{54}$

A country conditions expert can assist an asylum officer or IJ in the very difficult task of suspending his or her own biases and assumptions, and placing the facts and the individual asylum seeker before him or her in the culture of the context from which they came.

Giselle, ${ }^{55}$ a Cameroonian Bamileke woman, sought asylum in the United States on account of the persecution she had suffered based on her sexual orientation. During her asylum interview, Giselle responded to the asylum officer's questions about her marriage by explaining that it was a happy marriage. This contradicted the very basis of Giselle's claim, which included past persecution at the hands of her husband on account

51 See Matter of A-S-, 21 I. \& N. Dec. 1106 (BIA 1998); see also 8 C.F.R. §1003.1(d)(3)(i) ("Facts determined by the immigration judge, including findings as to the credibility of testimony" are subject to a "clearly erroneous" standard).

52 Memorandum from Phyllis Coven, Director of Office of International Affairs, Immigr. \& Naturalization Serv., to all INS Asylum Officers, Considerations for Asylum Officers Adjudicating Claims from Women 6-7 (May 26, 1995), reprinted at 7 Int'l J. Refugee L. 200 (1995), available at http://cgrs.uchastings.edu/documents/legal/guidelines_us.pdf (last visited Feb. 20, 2012). Demeanor means "how a person handles himself/herself physically; for example, maintaining eye contact, shifts in posture, and hesitations in speech."

53 Id.

54 Id.; see also Fiadjoe v. Att'y Gen., 411 F.3d 135 (3d Cir. 2005) (reversing and remanding IJ and BIA's adverse credibility finding in part based on failure to take into account gender guidelines on credibility, trauma, the sensitive nature of gender-based harm, and eye contact).

55 All individual case examples provided in this paper are from former or current clients of the Tahirih Justice Center who each provided consent to the anonymous use of the facts of their cases. 
of her sexual orientation. Giselle's case was referred to immigration court based on credibility concerns.

At first, Giselle could not even acknowledge that she had not told the truth, but after working with a psychologist for some time, Giselle explained that in the Bamileke culture, marriage is sacred and that a woman would lose respect and honor if she did not have a happy marriage. As such, Giselle had always covered up her husband's abuse and portrayed to her family, friends, and colleagues that he was a great man and they were very happy together. Thanks to this revelation, Giselle's attorneys submitted a supplemental affidavit from their country conditions expert to the immigration court. The expert affidavit affirmed that Giselle's explanation was consistent with Bamileke views on marriage and family life and that Giselle's reluctance to disclose her unhappy marriage to a stranger was understandable in the cultural context from which she came. With this supplemental information, the IJ was willing to grant asylum, overcoming the initial hurdle that Giselle's cultural background posed to her apparent credibility.

Walter Kälin's seminal article on the role that cultural differences can play in credibility determinations in asylum proceedings examines five main issue areas: (1) the manner in which the asylum seeker expresses him- or herself, (2) issues posed by interpretation, (3) cultural relativity of various notions and concepts, (4) differing perceptions of time, and (5) cultural relativity of the concepts of "lie" and "truth." 56 Kälin proposes that one way to overcome these hurdles would be for adjudicators to focus on asylum claims from "only one or a few culturally similar countries." 57 This is not the system we have in the United States, and country conditions experts can thus play a pivotal role in educating decisionmakers as to the many cultural contexts that they must confront on a daily basis.

\section{b. Explaining Conditions on the Ground in Country of Origin; Corroborating the Asylum Claim}

Corroborating evidence to support an asylum claim has taken on increasing importance in recent years. The REAL ID Act of 2005 amended the INA, which includes all provisions on asylum, to state that an applicant's testimony may be sufficient to sustain his burden

56 Walter Kälin, Troubled Communication: CrossCultural Misunderstandings in the Asylum-Hearing, 20 Int'1 Migration Rev. 230 (1986).

${ }^{57} \mathrm{Id}$. of proof without corroboration if it is demonstrably credible, persuasive, and probative of facts sufficient to demonstrate that the applicant is a refugee. ${ }^{58}$ However, if the trier of fact determines that corroborative evidence should be produced, it "must be provided unless the applicant does not have the evidence and cannot reasonably obtain the evidence." ${ }^{59}$ Input from a country conditions expert can be invaluable in cases where the applicant simply cannot provide corroborating evidence for her claim due to the circumstances of her flight or other factors.

Expert affidavits provided strong corroborating evidence to support the applicant's declaration in testimony in Zeyna's case. Zeyna is a Fulani Muslim woman from Guinea, who was forcibly subjected to FGM at the age of six and forced into marriage at the age of twelve. Zeyna feared return to Guinea because she had suffered threats and beatings for refusing to allow her husband's family to perform FGM on her daughter. The three country conditions experts retained for the case commented specifically on FGM and child marriage as practiced by the Fulani in Guinea. The expert's detailed affidavit corroborated Zeyna's own detailed account of these events. Although Zeyna herself had no evidence or other witnesses regarding the persecution she had suffered, the country conditions expert was able to confirm that the applicant's account conformed with her understanding of cultural practices in that country and specific ethnic group.

Country conditions experts can also fill in gaps in asylum claims where there is a lack of information on the treatment of a particular group or phenomenon in the generally available reports on the human rights situation in the country of origin. For example, a Cameroonian lesbian had been subjected, among other harm, to imprisonment, rape, and beatings at the hands of the police. Very little literature exists on the treatment of women in prison, and the expert retained for the case was able to explain the underreporting on this issue. Due to the extreme shame and stigma that survivors of gender-based violence often face, statistics or reports on gender-based violence within a country, for example, rape of male and female prisoners in Cameroon, may be underreported. Another recent case involved a Beninese woman who was promised

58 REAL ID Act of 2005, Div. B of Pub. L. No. 109-13, §101(a)(3), 119 Stat. 302, 303 (INA § 208(b)(1)(B)(ii), 8 U.S.C. §1158(b)(1)(B)(ii)).

${ }^{59}$ Id. 
in marriage to a vaudou/vodun follower and was forcibly subjected to widow rituals and inherited by his brother when the follower passed away. Few credible sources detail widow rituals and the vaudou/vodun religion in Benin. Where there are no other documents from human rights organizations, international bodies, or the U.S. State Department discussing a particular harm or treatment of a group, retaining an expert specifically to analyze the claim and provide any additional insight is invaluable.

For attorneys, experts can also sometimes play a key role in the early stages of a case by assisting the attorney in assessing and advising an individual on the merits of his or her potential asylum claim. Attorneys occasionally seek input from an expert on a particular country or culture when faced with a borderline case or one where the resolution of a legal issue may hinge on country conditions information. For example, a native and citizen of Mali had fled to Côte D'Ivoire and lived there safely for a number of years. Firm resettlement in another country is a bar to asylum eligibility in the United States. ${ }^{60}$ Therefore, the attorneys needed to understand whether this client was firmly resettled in Côte D'Ivoire. A preliminary consultation with an expert enabled the attorneys to verify the fluidity of movement across borders and the deep cultural ties of members of the tribe in question between the two countries. The attorneys quickly ascertained that they would be able to argue that the woman was not firmly resettled in Côte D'Ivoire because her persecutors could easily move across borders between Mali and Côte D'Ivoire. The attorneys could advise the individual on the merits of her potential asylum case and move forward with representation. Attorneys often undertake initial country conditions research to corroborate an individual's story prior to taking a case, but where that information is not easily available or is highly specialized, input from an expert at this early stage can be invaluable.

${ }^{60}$ See 8 C.F.R. $\$ 208.15$ (Firm resettlement is an "offer of permanent resident status, citizenship, or some other type of permanent resettlement" in another country prior to the applicant reaching the United States. An applicant is not firmly resettled where he or she establishes that "his or her entry into that country was a necessary consequence of his or her flight from persecution, that he or she remained in that country only as long as was necessary to arrange onward travel, and that he or she did not establish significant ties in that country" or where "the conditions of his or her residence in that country were so substantially and consciously restricted by the authority of the country of refuge that he or she was not in fact resettled.").

\section{c. Role of Experts in Addressing Concerns Regarding Social Visibility and Particularity in Particular Social Group Formulation}

As discussed briefly above, asylum law on particular social group, one of the five protected grounds on which persecution may be inflicted, is extraordinarily complex. Historically, the BIA found that a particular social group, as with the other grounds for asylum, had to be united by some "common immutable characteristic"-meaning that the shared characteristic was something that the individual either could not change (much like race) or should not be required to change (like religion or political opinion).

Again, in 2006 the BIA introduced two new concepts: "social visibility" and "particularity." 61 Social visibility, although a confusing term, is properly understood as the requirement that society in the country in question perceive that particular social group as a group. ${ }^{62}$ Particularity requires that "the proposed group can accurately be described in a manner sufficiently distinct that the groups would be recognized, in the society in question, as a discrete class of persons." 63

Social visibility requires that the adjudicator, whether an asylum officer or an immigration judge, weigh how a certain group is perceived in the relevant country. Particularity requires the adjudicator to examine whether it is possible to determine whether or not an individual is a member of the group. Thus, both of these new factors require a deep understanding of the cultural context in which the group exists. Advocates and commentators have expressed concern about how the social visibility and particularity factors may adversely affect the asylum claims of women and

61 I should note that the Matter of $C$ - $A$ - case was not actually the first time that the concept of social visibility was introduced. The BIA also alluded to consideration of such a factor in the 1999 decision in the Matter of $R-A$ case. See Matter of R-A-, 22 I. \& N. Dec. 906, 918 (BIA 1999) (finding it troubling that the IJ did not consider "whether anyone in Guatemala perceives this group to exist in any form whatsoever"; "we believe there must also be some showing of how the characteristic is understood in the alien's society ..."), remanded, 23 I. \& N. Dec. 694 (Att'y Gen. 2005), stay lifted, 24 I. \& N. Dec. 629 (Att'y Gen. 2008).

62 See supra note 23 (discussing Seventh and Third Circuits' rejection of social visibility and particularity and Ninth Circuit's reassessing of the concepts).

${ }^{63}$ Matter of S-E-G-, 24 I. \& N. Dec. 579, 584 (BIA 2008). 
those fleeing persecution based on sexual orientation. ${ }^{64}$ This is where country conditions experts can play an especially pivotal role in an asylum case.

Country conditions experts can assist an attorney in addressing social visibility and particularity because they often have insight on cultural attitudes towards different groups, which can help to establish that the group is in fact perceived as a group in the country in question or that group membership could be readily determined. A country conditions expert can explain how "divorced Nigerian women," "Cameroonian widows," "Liberian married women unable to leave the relationship," or "Tanzanian women in a domestic relationship and viewed as property by virtue of their status in a relationship" are groups that are indeed readily identifiable in a society.

A 2011 case involved Sarah, a young Congolese woman. When Sarah was just fifteen, Congolese government agents arrested, detained, raped, and threatened her because they were looking for her brother-inlaw and her half-sister, who were, unlike Sarah, both of Tutsi ethnic origin. Sarah's attorney argued that she was persecuted on account of her membership in a particular social group of "family members of Tutsis or suspected Tutsis." The country conditions expert in the case was able to explain in her affidavit and through her in-court testimony that in the Democratic Republic of the Congo "family members of Tutsis" would in fact be a socially visible groupperceived by society as a group - because of the interconnectedness of Congolese society and the strong animus towards Tutsis, who were often perceived as foreigners or outsiders. Further, the country conditions expert explained that targeting family members of Tutsis was actually a common strategy used by armed militias. This information helped to establish that the group was socially visible and that the persecution suffered was tied to a protected ground, which brings us to nexus, discussed below.

\section{d. Establishing Nexus of the Harm to a Protected Ground}

Experts play a similarly important role in establishing nexus to one of the five statutorily protected

\footnotetext{
64 See Fatma E. Marouf, The Emerging Importance of "Social Visibility" in Defining a "Particular Social Group" and Its Potential Impact on Asylum Claims Related to Sexual Orientation and Gender, 27 Yale L. \& Pol'y Rev. 47 (2008); see also Lindsay M. Harris \& Morgan Weibel, Matter of S-EG-: A Final Nail in the Coffin of Gang-Related Asylum Claims? 20 Berkeley La Raza L. J. 5 (2010).
}

grounds. Again, nexus means that the persecution suffered or feared was or is because of one of the five grounds. An applicant may provide either direct or circumstantial evidence of the persecutor's motive to show the connection to one of the five grounds. Direct evidence, perhaps statements made by the persecutor, is obviously most likely to come from the applicant herself. Experts, however, may be able to explain the cultural context for the persecution so that any link between the harm perpetrated or feared and the protected ground can be made. This could constitute circumstantial evidence of the persecutor's motive for the persecution.

For example, in Sarah's case discussed in section c, Sarah herself recounted that her persecutors, armed soldiers in the Eastern region of Congo, referred to her sister and brother-in-law and their being Tutsi when they raped her. This is direct evidence that the motive for their persecution was because of her membership in a particular social group of family members of Tutsis. The country conditions expert was able to provide circumstantial evidence regarding the motives of the soldiers. She explained that the Congolese national armed forces were made up of former rebel groups, and in the region in question they were made up of soldiers from a particular rebel faction who had historically fought against Tutsis and harbored racial animus towards Tutsis and to anyone associated with Tutsis, including by family ties. Thus, the country condition's expert affidavit was useful in establishing nexus of the harm suffered to one of the protected grounds-Sarah's membership in a particular social group of "family members of Tutsis or suspected Tutsis."

In the Guinean case discussed above, involving Zeyna, a Fulani Muslim woman, and her daughter who faced forced FGM, the country conditions experts spoke to the cultural motivations for FGM and child marriage as well as the role of extended family in a Fulani girl's life and how any opposition to the extended family's plan for a girl would be perceived. Thus, the experts provided the cultural context to address the issue of nexus of the persecution to a protected ground. Using the expert affidavits, the attorney was able to establish that the applicant had faced harm and would face further persecution because of her membership in the particular social group of "family members of uncut Fulani Muslim girls who oppose FGM." Social, economic, political, racial, or other dynamics at play are often critical in establishing nexus to a protected ground, and country conditions experts provide that cultural context. 


\section{e. Persecution by Non-state Actors, Government Willingness or Ability to Protect, and Internal Relocation}

In any asylum case, the applicant must prove that his or her government is unable or unwilling to protect the applicant from harm. In cases involving government persecution, this is a straightforward argument. In gender-based asylum cases, however, which often involve harm from a "non-state actor," this argument becomes more complex. Where a woman fears persecution from a family member or some other non-state entity, she must prove that the government is either unwilling or unable to protect her from persecution.

A government's unwillingness to protect may be shown through reference to a country's legal code. For example, in Cameroon there is no law to protect women from spousal abuse, and marital rape is indeed an exception under the law to the crime of rape. ${ }^{65}$ Thus, in that instance it may be quite straightforward to argue that the government is unwilling to protect a woman who fears harm from her spouse. Nonetheless, a country conditions expert who is able to speak to the culture of impunity for domestic abuse within Cameroon or to the unlikelihood that the police would take reports of domestic abuse seriously would strengthen the case.

A more challenging situation may arise where the government in question has made efforts to protect individuals like the applicant in question. For example, in a 2012 case involving a Ghanaian woman fleeing domestic violence, the attorney engaged a country conditions expert because Ghana had passed a fairly progressive domestic violence law in 2007. Thus, the applicant had to show that despite the legislation, the Ghanaian government remained either unwilling or unable to protect the applicant from harm. This required an expert with a deep understanding of not only the law itself, but also its implementation and the cultural context in which the law was being implemented. In situations like this, country conditions experts who understand the intersection of law and culture in a country may provide key evidence to explain persecution by non-state actors and government inability or unwillingness to protect.

${ }^{65}$ U.S. Department of State 2011 Human Rights Report: Cameroon, available at http://www.state.gov/j/drl/rls/hrrpt/ humanrightsreport/index.htm?dynamic_load_id $=186173$ ("The law does not address spousal rape."). DOS Human Rights Reports also are on the www.lexis.com service (Immigration $>$ Find Administrative Materials > Country Reports on Human Rights Practices).
Country conditions experts are always important in helping to establish that an individual does not have an internal flight alternative-meaning that she could reasonably relocate within her own country without facing harm. Where the persecutor is the government, persecution throughout a country is presumed, but in gender cases where the persecutor is often a non-state actor country conditions experts play a critical role in explaining how various societal and cultural factors would make internal relocation either impossible or unreasonable. For example, a country conditions expert can speak to the interconnectedness of the culture in a particular country and the networks or ties a particular persecutor may have within that country. Further, an expert can often address how a woman would be received culturally and socially in other locations in the country and whether she would be able to support herself economically.

\section{PRACTICAL TIPS FOR ATTORNEYS AND EXPERTS}

This section provides some concrete guidance and tips for both advocates and experts working together to present gender-based and other asylum cases. It is the aim of the author that these practice pointers start a discussion between and among attorneys and experts to establish a better understanding of best practices in presenting these cases and in the relationship between attorney and expert.

\section{a. Practice Pointers for Attorneys Working with Experts}

First, consider whether your case needs an expert. As Rachael Keast asserts in her 2005 article,

Where reliable documentary evidence is available that corroborates your client's claim, expert testimony may be unnecessary. Cases in which expert testimony may prove especially useful include those where: (1) there is a lack of documentary evidence focusing on the particular issue or geographical area; (2) conditions in the client's country are rapidly changing so current and reliable information is not available; and (3) the facts are very specific to the client, such as in cases involving psychological or physical conditions, or cultural norms as they impact the client's demeanor or ability to testify. ${ }^{66}$

\footnotetext{
${ }^{66}$ See Keast, supra note 41, at 1237.
} 
In some cases, then, there may be little utility in using a country conditions expert. ${ }^{67}$ Further, even in a case where you have worked with an expert, if the expert's final affidavit does not support your case or undermines it in any way, do not be afraid to abandon the use of that affidavit. Presenting the best possible case for your client is of course always the priority.

Second, once you have determined that an expert would help your case, build time into your case plan to research, locate, and secure expert assistance. Many experts have highly particularized knowledge, and thus one individual may be the expert on the specific issue in question in the relevant country or culture. Thus, those experts may be inundated with requests and may be able to accommodate only so many requests, or so many pro bono requests, within a specific time frame. Some good places to start in locating experts include:

- Academic associations, for example the American Political Science Association and the African Studies Association, which maintain databases of country conditions experts.

- $\quad$ FRLAN - Fahamu Refugee Legal Aid Program, a network that works to provide individuals and attorneys in the Global South with information and resources to assist in asylum and refugee determination processes. ${ }^{68}$

- Associations of returned Peace Corps volunteers, known usually as "Friends of [a certain country]." 69

- $\quad$ Equality Now, a global organization dedicated to ending violence against women and girls. ${ }^{70}$

- The Center for Gender and Refugee Studies, which maintains information for country conditions experts related to gender-based claims, which it can share in response to requests for technical assistance from attorneys handling gender-based or other social-group-based cases. $^{71}$

${ }^{67}$ See Hamid v. Gonzales, 417 F.3d 642, 646-47 (7th Cir. 2005) (court found that the IJ's denial of a motion for telephonic testimony for a London-based expert was not prejudicial, because the expert would not have said anything to change the outcome of the case).

${ }^{68}$ See http://frlan.org/, with experts listed by country.

${ }^{69}$ For example, see Friends of Guinea: http:// www.friendsofguinea.org/pcguinea/pcguinea.shtml.

${ }^{70}$ See www.equalitynow.org.

71 For cases involving gender-based claims, contact cgrs.uchastings.edu for technical assistance and suggestions on country conditions experts.
- Other attorneys handling cases, any listservs, or networks for asylum or immigration attorneys. ${ }^{72}$

If all else fails, conduct Internet searches on your issue and country, figure out anyone who has published articles or other pieces on the issue, and follow up with those individuals.

Third, manage expectations up front with your expert. The most successful expert affidavits generally result from strong communication between advocate and expert. Consider using a contract to outline the expert's role and also clarify confidentiality issues. ${ }^{73}$ Once roles are clarified, ensure that you have sent your expert all the relevant information that he or she needs to craft the affidavit, including a draft of your client's declaration in support of her asylum claim. Let the expert know that it will be important for you to review the draft affidavit and make suggestions to ensure that it not only supports the case, but also cannot undermine the case in any way. Finally, manage expert expectations when it comes to preparation to testify and explain that trial preparation will be important for both you as an attorney and the individual as an expert witness. It is important to note that given the backlogs in many immigration courts there could be unforeseeable delays or continuances in the case. Prepare your expert for a long wait.

Fourth, build in time to review drafts of your expert's proposed affidavit for content and for typos. The strongest expert affidavits generally develop over time as the attorney and expert home in on the key issues in the case. You will need to make sure that the expert affidavit is consistent with the other evidence you submit in support of your client's case or evidence already in the record. ${ }^{74}$ Further, any decisionmaker

72 In the Washington, DC, metropolitan area such a listserv is operated by the Central Area Immigrant's Rights Coalition. See http://www.caircoalition.org/.

${ }^{73}$ Increasingly academic experts are interested in writing about their service as expert witnesses in asylum proceedings and the cases in which they are involved. This is welcome, but does not come without ethical concerns for the protection of client information and attorney-client work product and communications. Consult your own organizational policies or local ethical rules to ascertain the bounds of confidentiality in working with an expert. Experts usually sign confidentiality agreements when retained for an asylum case.

74 See Matter of E-M-, 20 I. \& N. Dec. 77, 81 (BIA 1989) (" $[\mathrm{I}] \mathrm{n}$ determining the weight of an affidavit, it should be examined first to determine upon what basis the affiant is making the statement and whether the statement is internally consistent, plausible, or even credible. Most important is whether the statement of the affiant is consistent with other evidence in the record."). 
is likely to find your expert more credible and reliable if mistakes, including typographical errors, spelling mistakes, and minor factual discrepancies, are eliminated.

Fifth, request a curriculum vitae or résumé reflecting the expert's education, experience, research, and publications. Sometimes where experts have long résumés it may make sense to trim irrelevant publications or experience. Make sure that your expert is qualified to speak specifically to the issues involved in your case. ${ }^{75}$

Sixth, prepare adequately for immigration court by following all required procedures. Adequate preparation means drafting your direct examination questions for your expert ahead of time and communicating those questions to the expert, preferably in the form of a live preparation session. Observe all the general best practices when it comes to direct examination-just because you are not working with a client, do not assume that the answers you are looking for are intuitive to the expert. Craft the questions precisely to elicit the responses that you need to best support your client's case.

If possible, prior to your immigration court hearing seek a stipulation to your expert's qualifications from the government trial counsel. If you are unable to reach an agreement, ensure that you are well prepared to present your expert's credentials through voir dire on the day of the hearing.

Prior to your hearing, observe all the rules outlined in the immigration court practice manual, including submitting your witness list in accordance with $\S 3.3(\mathrm{~g})$ and specifying the length of time needed for each witness' testimony. When submitting your expert's affidavit, submit one with an original signature if possible ${ }^{76}$ and include your expert's CV or résumé. If your expert is unable to appear in person, timely file a

75 Diop v. Holder, 586 F.3d 587, 592 (8th Cir. 2009) (finding no prejudice where the IJ excluded testimony in a Senegalese asylum claim involving FGM where the expert had not been to Senegal or done any research specific to the Toucoleur tribe).

76 If an original signature is not available, argue that a copy will suffice (under FRE 1003, a duplicate is admissible if identical). motion for telephonic testimony. ${ }^{77}$ Just as you would with a client, consider whether you will need to request an interpreter for your expert and practice your direct examination using an interpreter.

Seventh, if your asylum case is denied and the IJ does not pay appropriate attention to your expert's affidavit or testimony, consider appealing the decision on that ground in addition to any other grounds for appeal. Several courts of appeals have found that an IJ's decision to exclude expert testimony was a violation of the applicant's due process rights. ${ }^{78}$

Further, circuit courts have also reversed and remanded where an IJ has not paid sufficient attention to expert testimony. For example, in Tassi v. Holder, the IJ discredited the testimony of a Cameroonian judge offered as an expert because the expert had no firsthand knowledge of the applicant's persecution in Cameroon. $^{79}$ On appeal, however, the Fourth Circuit cited FRE 703 and found that an expert is entitled to rely on factual underpinnings, including those based on hearsay, that are "of a type reasonably relied upon by

77 The Seventh Circuit has held that telephonic testimony is more acceptable for experts because observable factors, like demeanor, are less important in assessing expert testimony. See Hamid v. Gonzales, 417 F.3d 642, 645-46 (7th Cir. 2005). Make sure that you follow all required court procedures in requesting telephonic or live testimony. See Djedovic v. Gonzales, 441 F.3d 547, 550-52 (7th Cir. 2006) (court found IJ's denial of telephonic testimony from a professor of Balkan history nonprejudicial where the applicant's attorney filed the motion for telephonic testimony only two days prior to the hearing and then did not submit a written affidavit as the IJ requested); see also Singh v. Ashcroft, 398 F.3d 396, 407 (6th Cir. 2005) (holding that there was no error in the IJ excluding expert testimony where the attorney did not seek permission for expert testimony before the hearing).

78 See, e.g., Zolotukhin v. Gonzales, 417 F.3d 1073, 1076 (9th Cir. 2005) (holding that the IJ's denial of telephonic testimony of an expert in Moscow was prejudicial and violated the petitioner's due process rights where the IJ had also refused other testimony from the petitioner and his family members). In Ntangsi v. Gonzales, the Eighth Circuit declined to reach the issue of whether the applicant's due process rights were violated when telephonic testimony of her witnesses was denied, but the opinion suggests that failure to admit this evidence may have been a violation. 475 F.3d 1007 (8th Cir. 2007); see also Tadesse v. Gonzales, 492 F.3d 905, 909 (7th Cir. 2007) (holding that the IJ's refusal to consider a country conditions expert's affidavit or testimony was a violation of the applicant's "right to present evidence on her own behalf, for an IJ may not bar whole chunks of material evidence favorable to the petitioner."); Niam v. Ashcroft, 354 F.3d 652, 659-60 (7th Cir. 2003) (finding the exclusion of an expert's telephonic testimony prejudicial).

79660 F.3d 710, 721 (4th Cir. 2011). 
experts in the particular field in forming opinions or inferences on the subject." 80 The court found that the IJ had erroneously rejected probative aspects of the expert's testimony without providing a specific cogent reason for disregarding this evidence. ${ }^{81}$ The IJ had also erred in discrediting other evidence and finding the petitioners not credible, so the court vacated and remanded. $^{82}$

Similarly, in Tun v. Gonzales, the Eighth Circuit found a due process violation where the IJ gave no weight to an affidavit from a clearly qualified expert on country conditions in Burma because the expert was not available for cross-examination by the government. ${ }^{83}$ In that case there were other due process violations, including poor translation and denial of a medical expert's testimony, and the court reversed and remanded the case. ${ }^{84}$

Failure to take into account expert testimony alone may not be a sufficient ground for a successful appeal, but it can play a role in the decision of an appellate court to reverse the decision below. Courts have been especially inclined to remand cases where the IJ failed to give any explanation why specific testimony from an expert was excluded, or admitted but not considered. $^{85}$

$80 \mathrm{Id}$.

${ }^{81}$ Id. at $721-22$.

82 Id. at 726; see also Abulashvili v. Att'y Gen., 663 F.3d 197, 209 n.12 (3d Cir. 2011) (remanding based on a host of issues and urging that the BIA consider a country conditions expert's opinion on remand); Cole v. Holder, 659 F.3d 762, 773 (9th Cir. 2011) (holding that the BIA failed to give reasoned consideration to potentially dispositive testimony by an applicant's two expert witnesses because the BIA "mischaracterized the record with regard to one of the expert's consistency with the State Department reports, criticized that expert's testimony on a basis belied by the record, and failed even to acknowledge" the other expert witness); Koval v. Gonzalez, 418 F.3d 798 (7th Cir. 2005) (reversing and remanding where the IJ had excluded expert testimony and misapplied the standard for economic persecution).

83485 F.3d 1014, 1028-29 (8th Cir. 2007).

84 Id. at $1026-28,1029-31$.

85 See, e.g., Morgan v. Mukasey, 529 F.3d 1201, 1211 (9th Cir. 2008) (remanding where, among other errors, the BIA failed to adequately consider psychological expert reports); Leia v. Ashcroft, 393 F.3d 427, 434-45 (3d Cir. 2005) (remanding where the parties had agreed that a witness was a country conditions expert and the BIA approved an IJ's rejection of the expert's testimony without any explanation).
Finally, remember to let the expert know the result of your case if it is not immediately apparent from his or her involvement in proceedings.

\section{b. Practice Pointers for Country Conditions Expert Witnesses}

When you are considering getting involved in an asylum case:

- Clarify whether you are taking the case pro bono or for a fee. ${ }^{86}$

- Seek clarity on the forum: Is this case before the asylum office or the immigration court? Which immigration court? Does the attorney anticipate presenting your testimony live?

- Ensure that you have the expertise required on the case and can speak to the issues raised. For example, an expert on FGM in one particular tribe within a country may or may not be the best choice for a case involving an individual from a different tribe within that country or from a different country. ${ }^{87}$

- Clarify issues involving confidentiality. If you are an academic who would like to use a specific individual's story or your experience working on an asylum case in your own published writings, check with the attorney on the case to see whether this seems possible. Consider the ethical rules applying to your discipline and the use of "subjects" or individuals and their case histories.

A standard expert affidavit should be structured as follows:

(1) Outline of the expert's own credentials, including education, relevant research, expertise, publications, and awards;

(2) Statement regarding whether the expert is receiving payment for the affidavit and whether the expert is personally acquainted with the applicant or has met the applicant;

(3) Background on the relevant country conditions at issue;

(4) Discussion of the applicant's case, which should include at a minimum: the plausibility of the applicant's version of events and how it

${ }^{86}$ In Matter of M-, 5 I. \& N. Dec. 484 (BIA 1953), the BIA explained that the fact that an expert had appeared in many cases and was paid a fee was a valid consideration in evaluating the evidence, but was not dispositive in determining bias.

87 See Diop v. Holder, 586 F.3d 587 (8th Cir. 2009). 
comports with your understanding of the country in question, the likelihood of harm upon return to the country of origin, and the possibility of the applicant being able to reasonably relocate within the country of origin;

(5) Expert conclusions and an explanation of the basis for those conclusions.

Pitfalls to avoid when structuring and writing your report:

- A restatement of the applicant's story or declaration is not useful and will tend to irritate an IJ or asylum officer.

- Ensure that the tone of the report is not that of an advocate or someone acting as an adjudicator, but is that of an expert. While an expert may comment that, for example, based on his or her expertise the applicant's claim is highly credible, the expert should not advocate one way or another for a decision in the applicant's case. ${ }^{88}$

- Make sure that your affidavit is not conclusory in nature. The affidavit must contain sufficient facts and rationale to support the conclusions that you draw.

- Avoid submitting a standardized affidavit. Instead, tailor each report to the specific individual you are assisting. While it is understandable to copy and paste paragraphs from previous similar cases, make sure that as you edit the affidavit in its final stages all the information included applies to the case at hand. ${ }^{89}$ Your affidavit will be given less weight if it is not particularized to the specific case involved. ${ }^{90}$

${ }^{88}$ In general witnesses may not opine on questions of law. See Matter of Cruzado, 14 I. \& N. Dec. 513, 515 (BIA 1983 ) (holding that the opinion of a professor and others as to the proper construction of a state statute is not admissible). Therefore, the IJ or asylum officer will not give weight to any expert opinion on whether or not asylum should be granted. One exception to this rule is where an expert may actually be an expert on foreign law and/or procedures and may opine on those questions of law. See Matter of Rowe, 23 I. \& N. Dec. 962 (BIA 2006).

${ }^{89}$ Courts have properly excluded expert affidavits where the affidavits do not address the relevant issues in the case at hand. See, e.g., Kucana v. Holder, 603 F.3d 394 (7th Cir. 2010).

90 See Wang v. BIA, 437 F.3d 270, 274 (2d Cir. 2006) (finding that an affidavit from a retired U.S. census employee and immigration expert, the "Aird Affidavit" on coercive population control policies in China, had been used in more than 200 asylum cases and that the relevance and weight of an affidavit could be limited if it was "not prepared specifically for the petitioner and is not particularized to his circumstances.”).
Important points to keep in mind if you are asked to testify in immigration court:

- Consider making yourself available to testify under oath in court, ${ }^{91}$ either in person or by telephone. Although IJs will likely accept your affidavit as admissible without your testimony, your statement may be given less weight if you are not produced for cross-examination. ${ }^{92}$

- If it is not offered, ask for a preparation session with the attorney on the case.

- Prior to the hearing, you should be familiar with all of the questions the attorney will ask you and have been prepped on potential crossexamination questions.

- Be ready to answer questions about your qualifications - how much time you have spent physically within the country in question, how long and in what depth and capacity you have studied the country or culture at issue, your educational background, and your previous experience, if any, as an expert in asylum cases.

- Review your expert affidavit the day before you testify so that what you wrote is fresh in your mind.

- Let go of your preconceived notions of court practice. Immigration court is not bound by the rules of federal evidence, and therefore hearsay is admissible.

\section{CONCLUSION}

This article is not intended to provide an exhaustive review of the wide range of issues that arise when working with experts on asylum cases and genderbased asylum cases in particular, or when serving as an expert. Rather, it is intended to provide guidance to attorneys on the benefits and appropriate use of experts on these complex cases and to experts who evaluate and assess such cases. It is hoped that this article will foster further dialogue among attorneys, experts, and clients to better understand the nuances and needs of this specific genre of cases.

$$
* * * * *
$$

Lindsay M. Harris is an Immigration Staff Attorney at the Tahirih Justice Center, a legal services

91 Experts, like all witnesses in immigration court, must testify under oath or affirmation administered by the IJ. 8 C.F.R. $§ 1240.7($ b).

92 See Chen v. Gonzales, 434 F.3d 212, 218 (3d Cir. 2005) (finding an affidavit from a family member less probative in part because it was based on hearsay and the affiant was not available to be subjected to cross-examination). 
nonprofit organization serving immigrant women and girls fleeing gender-based violence. Lindsay leads the African Women's Empowerment Project, representing African immigrant women and girls in asylum proceedings, VAWA petitions, and applications for $\mathrm{T}$ visas for survivors of trafficking and $U$ visas for survivors of certain crimes. Prior to her work with Tahirih, Lindsay clerked for the Honorable Harry Pregerson of the Ninth Circuit's Court of Appeals, where she focused on immigration and asylum law. She teaches Refugee and Asylum Law as an Adjunct Professor at George Mason University School of Law in Arlington, Virginia. Lindsay is a graduate of the University of California-Berkeley, Boalt Hall School of Law, where she graduated order of the coif and was recognized for her clinical work in the International Human Rights Law Clinic and the East Bay Community Law Center with the Brian M. Sax Prize for Excellence in Clinical Advocacy. Lindsay also worked with the Center for Gender and Refugee Studies in San Francisco and in South Africa researching gender-based asylum claims.

A version of this paper was presented at the Rochester Institute of Technology's April 2012 Conable Conference in International Studies: "Refugees, Asylum Law, and Expert Testimony: The Construction of Africa and the Global South in Comparative Perspective." The author would like to thank colleagues and interns at the Tahirih Justice Center and the participants of the conference for their feedback and insight. Any views expressed within this article are those of the author and not the Tahirih Justice Center.

\section{SHOW YOUR STUFF!}

Send us the decisions in your cases. Let everyone know about your prowess.

Any reader interested in sharing information of interest to the immigration bar, including notices of upcoming seminars, newsworthy events, "war stories," copies of advisory opinions, or relevant correspondence from the DHS, DOJ, DOL, or DOS should direct this information to Daniel $\mathrm{M}$. Kowalski,dkowalski@thefowlerlawfirm.com., or Ellen Flynn, Senior Legal Editor, Bender's Immigration Bulletin, 121 Chanlon Rd., New Providence, NJ 07974, ellen.m.flynn@lexisnexis.com.

If you are interested in writing for the BULLETIN, please contact Dan Kowalski via e-mail atdkowalski@thefowlerlawfirm.com. We welcome your contributions. 


\section{IMMIGRATION NEWS}

(Continued from page 1809)

of the EOIR, and Laura Lichter, president of AILA, have criticized the report. See more information at http:// www.lexisnexis.com/community/immigration-law/blogs/ inside/archive/2012/11/02/lichter-osuna-oig-critique-ofimmigration-courts-lacks-nuance.aspx, (Lichter, Osuna: OIG Critique of Immigration Courts Lacks Nuance.)

Supreme Court - The U.S. Supreme Court heard oral argument in No. 11-820, Roselva Chaidez v. United States, on November 1. The question is whether the holding in Padilla v. Kentucky, that an attorney representing a noncitizen in a criminal case must give proper advice about immigration consequences, applies retroactively. Jeffrey L. Fisher argued for the petitioner, and Deputy Solicitor General Michael R. Dreeben for the government. The transcript is available in the United States Supreme Court Transcripts database on lexis.com, at 2011 U.S. Trans. 41048.

\section{REMINDER:}

The correct citation form for the BIB is Author, Title, 17 Bender's Immigr. Bull. 1811 (Nov. 15, 2012).

\section{RESEARCH TIP: \\ You can easily Shepardize ${ }^{\text {TM }}$ BIA precedent decisions on lexis.com. \\ Hit the "Shepard's" tab at the top of your document. If you are in a case, the citation of that case will appear in the box. If you want to check another case, type in that citation instead. Then hit the "Check" button, and get your results!}

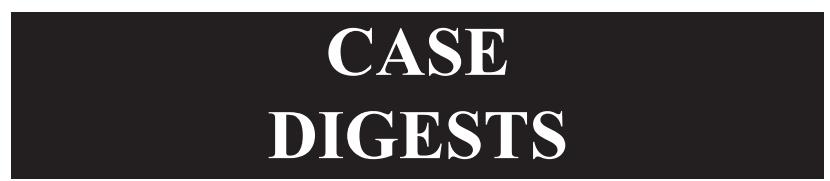

\section{FEDERAL COURT DECISIONS}

Court of Appeals:

Ali v. Holder, 686 F.3d 534, 2012 U.S. App. LEXIS 14890 (8th Cir. July 20, 2012): An IJ's denial of asylum and withholding of removal were upheld where the evidence established that the petitioner committed fraud and willfully misrepresented his identity, and his testimony before the immigration court was inconsistent, evasive, and unresponsive.

Yonis Ahmed Ali, also known as Hussain Isse Mohamud, from Somalia, was placed in removal proceedings after he disclosed during a naturalization interview that he had used a false identity when he entered as the spouse of a refugee. After so entering in 1995, he became an LPR in 1996. Facing removal, he applied for asylum and withholding of removal. He claimed that he had two different names as a result of being sent to live with an adoptive family as a child. He conceded that he had misrepresented other facts and made up stories during his naturalization interview. Further, his testimony was marked by inconsistencies and evasive and unresponsive answers. At the conclusion of the removal hearing, the IJ made an adverse credibility finding and denied relief. The IJ ordered removal upon finding that Ali had failed to rebut the removal charges against him with credible evidence. The BIA dismissed his appeal, and he sought judicial review.

The court (Murphy, Melloy, Colloton) denied review, finding that the record supported the IJ's adverse credibility determination and that Ali had failed to rebut the charges of removability based on his lack of a valid entry document and his willful misrepresentations as to several matters, including his true identity.

NOTE: For more on this subject, see Charles Gordon et al., Immigration Law and Procedure $\S 34.02$.

Borrome v. Att'y Gen., 687 F.3d 150, 2012 U.S. App. LEXIS 14676 (3d Cir. July 18, 2012): A conviction under the Food, Drug, and Cosmetic Act for wholesale distribution of prescription drugs without a license is not for an aggravated-felony controlledsubstance-trafficking crime, and the applicable FDCA provisions are not laws relating to a controlled substance for immigration purposes. 
Ramone Borrome was a citizen of the Dominican Republic who became an LPR in 1996. In 2002, the Food and Drug Administration charged him and two others with unlicensed wholesale distribution of prescription drugs. Borrome was not charged under the Controlled Substances Act. Following his conviction, he was sentenced to four months' imprisonment. Later, he was found to be removable as an alien convicted of an aggravated felony and of a controlledsubstance offense. In ordering removal, the IJ determined that the offense was analogous to a CSA conviction. The BIA affirmed, and Borrome filed for judicial review.

The court (Scirica, Ambro, Van Antwerpen) reversed the agency decision and vacated the order of removal upon finding that he had not been convicted of illicit trafficking in a controlled substance and that the FDCA provisions were not laws relating to a controlled substance.

NOTE: For more on this subject, see Charles Gordon et al., Immigration Law and Procedure $\S \oint 63.03,71.05$.

Matul-Hernandez v. Holder, 685 F.3d 707, 2012 U.S. App. LEXIS 14584 (8th Cir. July 17, 2012): "Guatemalans returning from the United States who are perceived as wealthy" was not a cognizable social group, for it would not be perceived as a determinable social group by society or subject to a higher incidence of crime than the rest of the population.

Julio Matul-Hernandez was a native of Guatemala who illegally entered in 1993. As a teenager, he had been forced into the Guatemalan army, had deserted, and had lived in Mexico for several years before coming to the United States. While in Mexico, he traveled often to Guatemala. During one of his visits, he was threatened by three armed men in his father's store. Charged in removal proceedings, he applied for asylum and withholding of removal. He testified that his brother and uncle were victims of violent crime in Guatemala. He argued that he would be persecuted in Guatemala if removed because he was a member of a particular social group: Guatemalans returning from the United States who are perceived as wealthy. At the time of his removal hearing, he owned a grocery store in Nebraska. The IJ denied the relief sought, but granted voluntary departure. The BIA dismissed an appeal, and MatulHernandez sought judicial review.

The court (Wollman, Colloton, Benton; opinion by Wollman) denied his petition for review, finding that he had failed to establish that he was a member of a "particular social group" targeted for persecution, as his proposed group would not be perceived as a determinable social group by society or subject to a higher incidence of crime than the rest of the population.

NOTE: For more on this subject, see Charles Gordon et al., Immigration Law and Procedure $\S 33.04$.

Dayo v. Holder, 687 F.3d 653, 2012 U.S. App. LEXIS 14302 (5th Cir. July 12, 2012): Substantial evidence, including inconsistent statements and lack of corroborating evidence, supported the BIA's determination that the petitioner was not credible and that he failed to establish that his native country persecuted asylum-seekers. But he could submit a new claim for relief after the confidentiality of the original asylum application was breached by the government.

Kingsley Dayo, a/k/a Kingsley Pedersoli, A Dayo Kingsley, Kingsley Dayo Pedersoli, Kingsley J. Dayo, and Darryl Lamont Gates, was a Nigerian facing removal for illegal entry in 2004. Appearing before an IJ in 2009, Dayo denied the allegation. The evidence indicated that he had entered using someone else's passport and birth certificate. The IJ ordered removal, and Dayo applied for asylum, withholding of removal, and CAT relief. The IJ denied the relief, finding that Dayo was not credible and that his asylum application was untimely. Following the BIA's affirmance, a petition for judicial review was dismissed in part and denied. Dayo moved to reopen his removal proceedings because the government, in the course of obtaining travel documents from the Nigerian consulate to facilitate removal, inadvertently disclosed that he had applied for asylum. The BIA thus reopened his proceedings and remanded to the IJ, allowing Dayo to submit a new request for relief based on the breach of confidentiality. The IJ took further evidence with regard to the breach of confidentiality and its consequences. The IJ determined that he was not credible and that he had not shown that the Nigerian government persecuted asylum-seekers. The BIA affirmed, and Dayo sought judicial review.

The court (Reavley, Smith, Prado; opinion by Smith) denied the petition upon finding that, while asylum-seekers may apply for separate relief based on a breach of confidentiality, substantial evidence supported the determination that he was not credible and that he had failed to establish that the Nigerian government persecuted asylum-seekers.

NOTE: For more on this subject, see Charles Gordon et al., Immigration Law and Procedure $\S 34.02$. 
Liu v. Mund, 686 F.3d 418, 2012 U.S. App. LEXIS 14223 (7th Cir. July 12, 2012): The beneficiary of an I-864 affidavit of support, seeking its enforcement, has no legal duty to mitigate damages by seeking employment.

Wenfang Liu was a native of China who married a U.S. citizen. He executed an I-864 affidavit of support, in which he agreed to provide her with whatever support was necessary to maintain her at an income of at least $125 \%$ of the federal poverty level. The parties were subsequently divorced. Per the divorce court, the ex-husband was required to provide monthly support to Liu, exclusive of any support obligations pursuant to the I-864. The divorce court's support order included an obligation on her part to seek work. She sued to enforce his support obligation under the I-864. The district court (Conley) held that she was not entitled to support pursuant to the I-864 because she had not actively sought employment during the period at issue. She appealed.

The court (Posner, Rovner, Wood; opinion by Posner) reversed upon finding that the beneficiary had no legal duty, by statute or regulation, to mitigate damages.

NOTE: For more on this subject, see Charles Gordon et al., Immigration Law and Procedure $\S 63.05$.

Dandamudi v. Tisch, 686 F.3d 66, 2012 U.S. App. LEXIS 14090 (2d Cir. July 10, 2012): A state law limiting pharmacist licenses to citizens and LPRs was unconstitutional.

New York state law provided that pharmacists' licenses could be issued only to U.S. citizens and LPRs. The statute excluded all other aliens from the pharmacy profession, including those who had received authorization from the federal government to work in the United States temporarily. Twenty-six alien pharmacists with temporary authorization from the federal government to work in the United States challenged the constitutionality of the statute, alleging, inter alia, violation of their equal protection rights and encroachment on the federal government's exclusive power to regulate immigration. The parties filed cross-motions for summary judgment. The district court entered summary judgment for the plaintiffs and enjoined the state's enforcement of the statute upon finding that it was unconstitutional as applied to aliens admitted and given the right to work pursuant to U.S. immigration policy. The state defendants appealed.

The court (Wesley, Hall, Underhill; opinion by Wesley) affirmed upon finding that the plaintiffs were part of a suspect class, that any discrimination by the state against them was subject to strict-scrutiny review, and that the statute violated the plaintiffs' equal protection rights and encroached upon the federal government's regulation of immigration.

NOTE: For more on this subject, see Charles Gordon et al., Immigration Law and Procedure $\S \S 6.05,9.03$.

Mendoza v. United States, 2012 U.S. App. LEXIS 15871, renumbered 13225 (3d Cir. June 28, 2012): Nearly five-year delay in filing a petition for a writ of error coram nobis barred the effort for such relief.

Mario Mendoza was a native of Ecuador who was charged with mortgage fraud and entered a guilty plea. Counsel did not advise him that, because his offense was an aggravated felony, his conviction could result in his removal. However, prior to his sentencing in September 2006, he learned from his presentence investigative report that it could. He was sentenced to probation and ordered to make restitution and cooperate with immigration officials. He was ordered removed. In June 2011, he filed a petition for a writ of error coram nobis, alleging ineffective assistance of counsel. The district court denied the petition upon finding that it was filed after an unreasonable delay. Mendoza filed a timely appeal.

The court (Ambro, Vanaskie, Aldisert; opinion by Aldisert) affirmed upon finding that the unreasonable delay in filing his error coram nobis petition blocked his efforts to seek relief.

NOTE: For more on this subject, see Charles Gordon et al., Immigration Law and Procedure $\S 74.08$.

\section{District Court:}

Pedersen v. Office of Personnel Mgmt., 2012 U.S. Dist. LEXIS 106713 (D. Conn. July 31, 2012): The Defense of Marriage Act, with its definitions of "marriage" and "spouse" bearing no rational relation to the statute's purported objectives of defending the institution of heterosexual marriage, defending traditional notions of morality, protecting state sovereignty and democratic self-governance, and preserving scarce governmental resources, violates the equal protection rights of homosexuals under the Fifth Amendment.

The plaintiffs were homosexuals who were legally married to individuals of the same sex in Connecticut, Vermont, and New Hampshire. Their suit challenged the constitutionality of the Defense of Marriage Act. 
In particular, they alleged that the definitions of "marriage" and "spouse" in DOMA violated their equal protection rights under the U.S. Constitution. They claimed that the definitions excluded homosexual couples legally married under state law from receiving recognition and benefits under the numerous federal laws that relied on the DOMA definitions. The plaintiffs had been denied federal marital benefits or had sought to file federal income tax returns based on their married status. The plaintiffs moved for summary judgment, and the defendants moved to dismiss the plaintiffs' complaint for failure to state a claim.

The court (Bryant) granted the plaintiffs summary judgment and denied the defendants' motion to dismiss upon finding that homosexuals were a suspect class whose claims were entitled to a heightened level of judicial scrutiny and that DOMA, even under a more deferential level of judicial scrutiny, did not bear a rational relation to its stated objectives and therefore violated the equal protection principles incorporated in the Fifth Amendment.

NOTE: For more on this subject, see Charles Gordon et al., Immigration Law and Procedure $\S \S 6.02,36.02$.

\section{BIA DECISIONS}

\section{Precedent:}

Matter of Sanchez-Herbert, 26 I. \& N. Dec. 43 (BIA 2012): When an alien fails to appear for a hearing because he has left the United States, termination of proceedings is not appropriate if he had received proper notice of the hearing and was removable as charged.

DHS charged that Ramiro Sanchez-Herbert was inadmissible for being an alien in the United States without admission or parole. He appeared at a master calendar hearing, conceded removability, then received several continuances until February 2011, when counsel appeared without him and moved to terminate proceedings. Counsel presented evidence that SanchezHerbert had voluntarily returned to Mexico. DHS urged a hearing in absentia, but the IJ granted termination on the ground that she lacked jurisdiction once he left the United States. DHS appealed.

The BIA (Malphrus, Creppy, Liebowitz; opinion by Malphrus) sustained the appeal and reinstated the proceedings. It explained that departure does not remove jurisdiction, as long as the NTA has been properly filed with the court and seems to still apply. The
BIA drew on the decision in Matter of Brown, 18 I. \& N. Dec. 324 (BIA 1982). It pointed out that the purpose of in absentia proceedings is to see whether DHS can show removability and proper notice. If it can, the IJ should order removal, which provides consequences that would not apply if the IJ only terminates proceedings - as though DHS had not shown notice or removability.

NOTE: For more on this subject, see Charles Gordon et al., Immigration Law and Procedure $\S \S 1.06,64.03$.

Matter of Davey, 26 I. \& N. Dec. 37 (BIA 2012): The term "single offense" in INA $\$ 237(a)(2)(B)(i)$ refers to a single incident, not one statutory crime, so that a guilty plea to possession of ten grams of marijuana and drug paraphernalia - the bag holding the drug_ did not provide multiple "offenses."

Jennifer Adassa Davey, a Jamaican, pleaded guilty to possession of less than ten grams of marijuana in a plastic baggie - possession of marijuana and of drug paraphernalia in violation of Arizona Revised Statutes $\S 13-3405(\mathrm{~A})(1)$ and 13-3415(A). In removal proceedings, an IJ ordered her released from detention on a $\$ 2,000$ bond. The IJ concluded that DHS was "substantially unlikely" to prove that her convictions supported a charge under INA $\S 237(a)(2)(B)((i), 8$ U.S.C. $\S 1227(\mathrm{a})(2)(\mathrm{B})(\mathrm{i})$. The IJ reasoned that the conviction was for "a single offense involving possession for one's own use" of no more than thirty grams of marijuana. DHS appealed, arguing that under INA $\S 236(\mathrm{c})(1)(\mathrm{B})$, 8 U.S.C. $\S 1226(\mathrm{c})(1)(B)$, the IJ lacked jurisdiction to redetermine her custody status.

The BIA (Cole, Pauley, Greer; opinion by Pauley), posited two possible interpretations of "single offense": a single generic crime, as DHS favored, and a single incident, as Davey and the IJ preferred. Although the BIA had not previously construed that language in $\S 237(\mathrm{a})(2)(\mathrm{B})(\mathrm{i})$, it had construed the term in INA $\S 212(\mathrm{~h}), 8$ U.S.C. $\S 1182(\mathrm{~h})$, and held that it refers to a single event. The IJ had followed that case, Matter of Martinez Espinoza. The BIA agreed, saying that the statutory language requires a "circumstance-specific" inquiry along the lines described in Nijhawan $v$. Holder, rather than "a focus on the formal elements of generic offenses." Then, turning to the facts of the case, the BIA concluded that DHS indeed was substantially unlikely to meet its burden of proving that Davey was not within the "personal use" exception. The BIA pointed out that the bond order came after a removal hearing and the dismissal of the $\S 237(a)(2)(B)(i)$ charge on the merits. 
NOTE: For more on this subject, see Charles Gordon et al., Immigration Law and Procedure $\S \S 63.03,71.05$.

\section{AAO DECISIONS}

Matter of $X$, file [no. not provided], (AAO Jan. 5, 2012) (Nebraska Service Center): A professor who had received numerous awards, published a graduatelevel text and several prizewinning papers, and been active in his field as a review panel and professional association participant, failed to satisfy at least three of the regulatory criteria for extraordinaryability classification and otherwise failed to establish the requisite national or international acclaim or his position within the small percentage at the very top of his field.

The petitioner, a professor at MIT and a research scientist, sought classification as an alien of extraordinary ability in the sciences. He had published a graduate-level text and several prizewinning papers, had served on review panels, and was a member of multiple professional associations. The petitioner also had received multiple distinguished service and contribution awards. The director denied the petition, finding that he had failed to establish the requisite national or international acclaim. The petitioner appealed.

The AAO dismissed the appeal upon finding that the petitioner had failed to satisfy at least three of the regulatory criteria and, despite substantial achievement in his chosen field, ultimately failed to meet the high standard of national or international acclaim and a position at the highest level of his field.

NOTE: For more on this subject, see Charles Gordon et al., Immigration Law and Procedure §39.03.

Matter of X, file [no. not provided], (AAO Jan. 10, 2012) (Texas Service Center): A senior software engineer who had received three lesser awards, published one scholarly article with no documented citations to it, played a critical role in one distinguished organization, and received above-average but not extraordinary compensation for his work failed to satisfy at least three of the regulatory criteria for EB-1-1 classification and otherwise failed to establish the requisite national or international claim in his chosen field.

The petitioner, a senior software engineer, sought classification as an alien of extraordinary ability in the sciences. He had received three lesser awards for his work, but he gave little or no documentation of their national or international significance. The petitioner also submitted the abstract of one article published under his name, with no evidence of scholarly citations to it, and evidence that he had played a critical role in one organization of distinguished reputation in his field. He submitted evidence of his compensation, but it was not sufficiently high to reflect national or international acclaim or a position at the top of his field. The director denied the petition, finding that the petitioner had failed to establish the requisite national or international acclaim. The petitioner appealed.

The AAO dismissed the appeal upon finding that the petitioner had failed to satisfy at least three of the regulatory criteria and, despite significant achievement in the field of software engineering, ultimately failed to establish the requisite national or international acclaim for his work.

NOTE: For more on this subject, see Charles Gordon et al., Immigration Law and Procedure $\S 39.03$.

Matter of $X$, file [no. not provided], (AAO Jan. 11, 2012) (Nebraska Service Center): An educator and activist in end-of-life choices, despite authorship, citations, recommendations, and a significant national award nomination, failed to submit "extensive documentation" of his achievements, failed to satisfy at least three of the regulatory criteria for extraordinary-ability classification, and otherwise failed to establish the requisite national or international acclaim or his position within the small percentage at the very top of his field.

The petitioner, an educator and activist in end-oflife issues, sought classification as an alien of extraordinary ability. Evidence indicated that the petitioner had been repeatedly nominated for a national award in Australia, was the subject of numerous professional publications, had authored three books and numerous articles, had been cited by others, and was the subject of numerous recommendations extolling his ability. However, the director denied the petition, finding that the petitioner had failed to establish extraordinary ability or sustained national or international acclaim. The petitioner appealed. On appeal, his counsel claimed that he satisfied at least three of the regulatory criteria for EB-1-1 classification.

The AAO dismissed the appeal upon finding that he had failed to satisfy at least three of the regulatory criteria, failed to submit the requisite "extensive documentation" of achievement, and otherwise failed to establish the requisite national or international acclaim. 
NOTE: For more on this subject, see Charles Gordon et al., Immigration Law and Procedure $\S 39.03$.

Matter of $X$, file [no. not provided], (AAO Jan. 11, 2012) (Nebraska Service Center): A motion seeking to reopen administrative proceedings resulting in the denial of a petition seeking classification as an alien of extraordinary ability was dismissed where the petitioner failed to submit a statement regarding any related judicial proceedings and, further, to submit any new or previously unavailable evidence in support of the motion to reopen.

The petitioner had sought classification as an alien of extraordinary ability. The director denied the petition in April 2008. On appeal, the AAO withdrew the director's decision and remanded for further consideration. The director certified his denial to the AAO in November 2009. In April 2010, the AAO affirmed the director's adverse decision. The petitioner moved to reopen the proceedings before the AAO. In filing the motion, the petitioner failed to submit the required statement indicating whether the validity of the decision had been or was the subject of judicial proceedings. The petitioner also resubmitted previous evidence in support of the motion, but not new or previously unavailable evidence.

The AAO dismissed the MTR and affirmed the denial upon finding that the petitioner had failed to meet one of the regulatory requirements for the filing of a motion and, on the merits, failed to identify the regulatory criteria at issue and to submit "new" evidence in support of the motion to reopen.

NOTE: For more on this subject, see Charles Gordon et al., Immigration Law and Procedure $\S \S 3.02,39.03$.

Matter of $X$, file [no. not provided], (AAO Jan. 13, 2012) (Nebraska Service Center): An appeal from a service center director's denial of a petition seeking classification as an alien of extraordinary ability, received by the service center thirty-five days after the issuance of the director's decision, was rejected as untimely and returned to the director for consideration as a motion.

The petitioner sought classification as an alien of extraordinary ability. The service center director's decision denying the petition was issued on March 16, 2010. Although counsel dated the petitioner's appeal "April 16, 2010," it was not received by the service center until April 20, 2010, thirty-five days after the director's decision was issued.

The AAO rejected the appeal from and returned the matter to the director for consideration as a motion upon finding that the appeal was untimely.

NOTE: For more on this subject, see Charles Gordon et al., Immigration Law and Procedure \$ 3.02. 


\section{VISIT THE IMMIGRATION LAW COMMUNITY FOR THE LATEST NEWS, CASES, AND CRUCIAL INFORMATION}

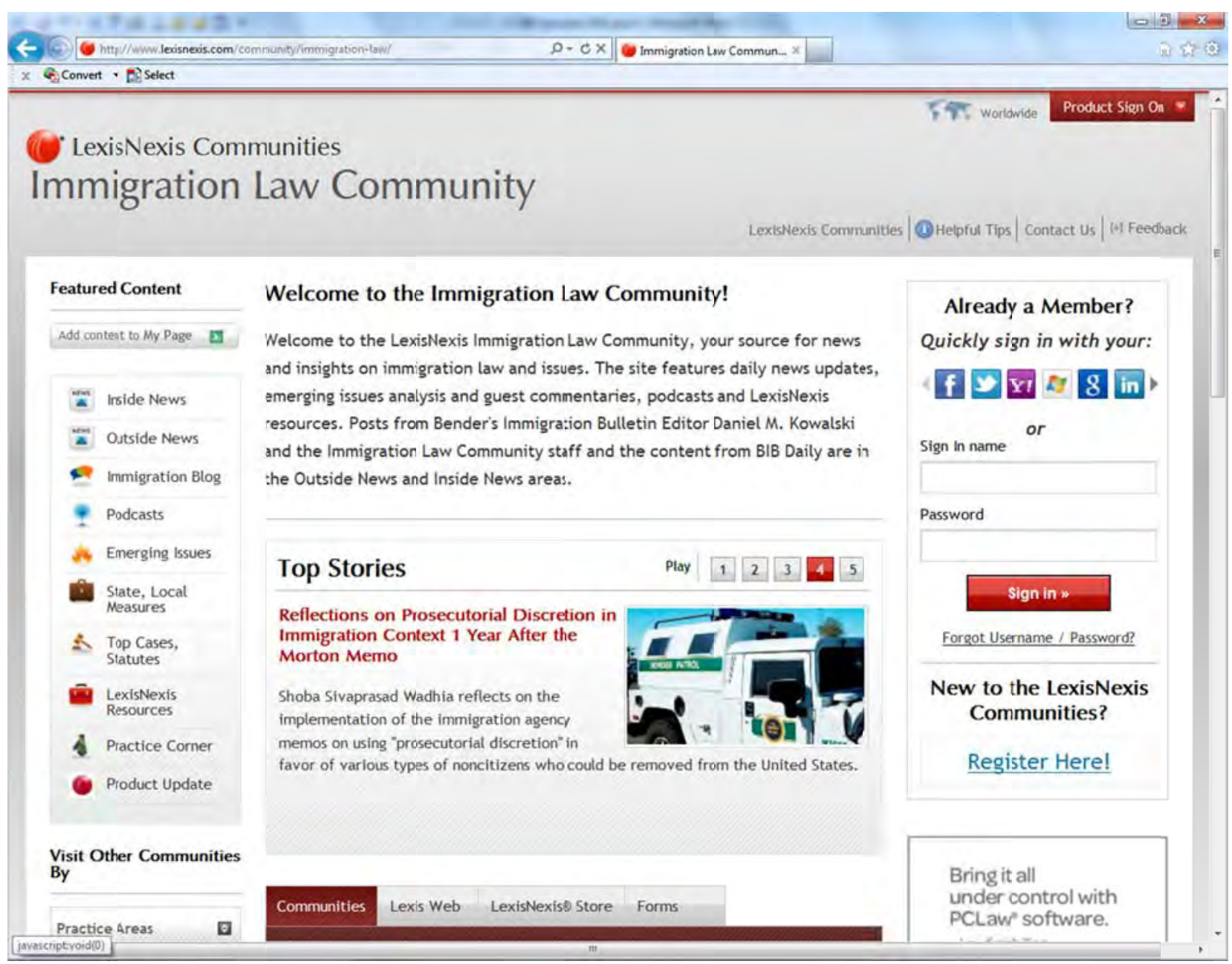

http://www.lexisnexis.com/community/immigration-law/ 


\section{GOVERNMENT DOCUMENTS}

\section{FEDERAL REGISTER}

Final Rules

Department of Homeland Security, Office of the Secretary; "Designation of Taiwan for the Visa Waiver Program"; Action: Final rule: On October 20, 2012, the Secretary of Homeland Security, in consultation with the Secretary of State, designated Taiwan for participation in the Visa Waiver Program. This final rule updates the list of countries designated for participation in the VWP by adding Taiwan. It took effect on November 1, 2012. 77 Fed. Reg. 64,409 (Oct. 22, 2012).

Department of State, Bureau of Consular Affairs; "Repeal of Regulations on Marriages": Action: Final rule. Pursuant to Executive Order 13563, the Bureau repealed 22 C.F.R. Pt. 52, relating to the role of consulates in marriages, as outdated, duplicative, and unnecessary. The rule was effective October 29, 2012. 77 Fed. Reg. 65,477 (Oct. 29, 2012).

Department of the Treasury, Office of Foreign Assets Control; "Iranian Transactions Regulations"; Action: Final rule: The Treasury Department is changing the heading of the Iranian Transactions Regulations to the Iranian Transactions and Sanctions Regulations (ITSR), amending the renamed ITSR, and reissuing them in their entirety. Visas are discussed in 31 C.F.R. $\S 560.505$. The final rule can be downloaded from http://www.gpo.gov/fdsys/pkg/FR-2012-10-22/ pdf/2012-25770.pdf. It is effective as of October 22, 2012. 77 Fed. Reg. 64,664 (Oct. 22, 2012).

\section{ICE MEMORANDUM}

\section{- Enforcement Actions at or Focused on Sensitive Locations}

Editorial Summary: In this memo, dated October 24, 2011, ICE Director John Morton set forth ICE policy regarding certain enforcement actions at or focused on sensitive locations. The memo is available at http:// www.ice.gov/doclib/publicadvocate/pdf/10029.2-po licy.pdf and is reprinted at Appendix C.

\section{USCIS DOCUMENTS}

\section{- USCIS-AILA Meeting October 9, 2012}

Editorial Summary: On October 9, 2012, USCIS hosted an engagement with AILA representatives. USCIS discussed issues related to waivers of inadmissibility, NSEERS, H-1B visa cap registration, the Entrepreneurs in Residence Program, and other issues. USCIS's responses to AILA's questions are reprinted at Appendix D.

\section{- USCIS Field Operations-AILA Meeting on October 4, 2012}

Editorial Summary: On October 4, 2012, the USCIS Field Operations Division hosted an engagement with AILA representatives. USCIS discussed issues related to biometrics collection, NSEERS registration, customer service, and other issues. USCIS's responses to AILA's questions are reprinted at Appendix E.

\section{DOL/ETA GUIDANCE}

\section{- TEGL No. 9-12: Human Trafficking: The Role of the Public Workforce System in the Delivery of Services and Referrals to Victims of Trafficking}

Editorial Summary: The Employment and Training Administration released a Training and Employment Guidance Letter on October 24, 2012, covering human trafficking. The TEGL is reprinted at Appendix $\mathbf{F}$ and is online at http://wdr.doleta.gov/directives/attach/ TEGL/TEGL_9_12.pdf.

\section{STATE DEPARTMENT CABLE}

\section{- B-1 in Lieu of H Cable}

Editorial Summary: The State Department sent a cable to all diplomatic and consular posts on October 12, 2012, regarding B-1 in Lieu of H-1B and H-3 guidance. This cable supersedes the June 21, 2012 B-1 in Lieu of H ALDAC that was published as Appendix C in the July 15, 2012 issue (17 Bender's Immigr. Bull. 1427). The new cable is reprinted at Appendix G. 


\section{APPENDIX A (for summary see page 1809)}

\section{Agreement \\ Between \\ the United States of America \\ and \\ the Russian Federation \\ Regarding Cooperation in Adoption of Children}

The United States of America and the Russian Federation, hereinafter referred to as the Parties,

Recognizing that the child, for the full and harmonious development of his or her personality, should grow up in a family environment, in an atmosphere of happiness, love, and understanding;

Recognizing the necessity to take appropriate measures to keep the child with his or her birth family, but where that is not possible, to place the child with a substitute family in the Country of Origin for the purposes of upbringing;

Recognizing that intercountry adoption of a boy or girl (hereinafter adoption) may offer the advantages of a permanent family to a child if a suitable family cannot be found for the child in the Country of Origin;

Recognizing that a child adopted in accordance with the procedures established by this Agreement should be provided with the same advantages and the same rights that are guaranteed to him or her as a citizen or lawful permanent resident of the Receiving Country (whichever applies);

Confirming that the adoption of children who are citizens of one Party by citizens of the other Party shall take place on the basis of respect for the 


\section{ApPEndix A (continued)}

2

fundamental values and principles of each Party and taking into account the principles of the Convention on the Rights of the Child of November 20, 1989, and the Convention on Protection of Children and Co-operation in Respect of Intercountry Adoption of May 29, 1993;

Have agreed as follows:

\section{GENERAL PROVISIONS}

\section{Article 1}

For purposes of this Agreement, the terms used shall mean the following:

1) "Receiving Country" - the Party where the child habitually will reside or resides after his or her adoption.

2) "Country of Origin" - the Party of which a child is a citizen and where he or she habitually resides or resided before the adoption.

3) "Executive Body":

for the United States of America - the Department of State of the United States of America;

for the Russian Federation - the Ministry of Education and Science of the Russian Federation.

The Parties shall inform each other through diplomatic channels of a change of Executive Bodies. 


\section{APPENDIX A (continued)}

4) "Regional Authority":

for the United States of America - an institution (a body or organization) of a state, territory, or tribe, or any other local government institution that performs functions related to placing children left without parental care in accordance with the domestic laws of the United States of America;

for the Russian Federation - an executive authority of a constituent entity of the Russian Federation that is entrusted with the functions of a regional operator of the governmental database regarding children left without parental care.

5) "Authorized Organization":

If the United States of America is the Receiving Country - an entity from the United States of America that is authorized to perform activities in the field of intercountry adoption in accordance with the domestic laws of the United States of America, and that has received authorization to perform activities in the field of intercountry adoption in the territory of the Russian Federation in accordance with the domestic laws of the Russian Federation and this Agreement;

If the Russian Federation is the Receiving Country - a governmental body or an organization of the Russian Federation that is authorized to perform activities in the field of intercountry adoption in the territory of a foreign state in accordance with the procedure established by the domestic laws of the Russian Federation, and that has received 


\section{APPENDIX A (continued)}

4

authorization required in accordance with the domestic laws of the United States of America (if such authorization is required) to perform activities in the field of intercountry adoption in the territory of the United States of America in accordance with this Agreement.

6) "Competent Authority that performs an inspection of the living conditions of prospective adoptive parents":

for the United States of America - an entity authorized in accordance with the domestic laws of the United States of America to prepare a conclusion regarding the living conditions of the prospective adoptive parents;

for the Russian Federation - the guardianship and trusteeship body for the place of residence of the prospective adoptive parents.

7) "Competent Authority that issues a conclusion regarding the suitability and eligibility of prospective adoptive parents to adopt a child":

for the United States of America - the United States Citizenship and Immigration Services, U.S. Department of Homeland Security;

for the Russian Federation - the guardianship and trusteeship body for the place of residence of the prospective adoptive parents.

8) "Competent Authority that issues a conclusion regarding the eligibility of the prospective adoptive parents to transfer the child from the Country of Origin to the Receiving Country": 


\section{APPENDIX A (continued)}

for the United States of America - the United States Citizenship and Immigration Services, U.S. Department of Homeland Security;

for the Russian Federation - the territorial branch of the Federal Migration Service for the place of residence of the prospective adoptive parents.

9) "Competent Authority that makes a decision regarding adoption":

for the United States of America - the state, territorial, tribal or other local court that has jurisdiction to make decisions regarding the adoption of the child;

for the Russian Federation - the Supreme Court of the Republic, the Krai or Oblast Court, the federal-level city Court, the Autonomous Oblast Court, or the Autonomous Okrug Court for the place of residence or location of the child being adopted.

10) "Competent Authority that monitors the living conditions and upbringing of the adopted child":

for the United States of America - an Authorized Organization providing monitoring of the living conditions and upbringing of the adopted child at the place of residence of the adoptive parents and the adopted child;

for the Russian Federation - the guardianship and trusteeship body for the place of residence of the adoptive parents and the adopted child. 


\section{APPENDIX A (continued)}

\section{6}

11) "domestic laws":

for the United States of America - federal laws and regulations, and laws and regulations of the U.S. states, the District of Columbia, and the U.S. territories and tribal authorities;

for the Russian Federation - the laws and regulations of the Russian Federation and constituent entities of the Russian Federation.

12) "territory" (as it pertains to the United States of America) - the territory included in the definition of "United States" in the Immigration and Nationality Act of the United States of America.

\section{Article 2}

1. In accordance with this Agreement, an adopted child shall enjoy with respect to the adoptive parents and their relatives and the adoptive parents shall enjoy with respect to the adopted children property and personal nonproperty rights and responsibilities in the Receiving Country that arise by virtue of the adoption, which are equal to the rights resulting from an adoption of a child who is a citizen of the Receiving Country.

2. This Agreement shall be applicable in those situations when:

a) a child under 18 years of age who is a citizen of one Party (the Country of Origin) and habitually resides in its territory is adopted in the territory of the Country of Origin and transferred to the Receiving Country by: 


\section{ApPEndix A (continued)}

\section{7}

i) both spouses who habitually reside in the territory of the other Party (the Receiving Country), and at least one of whom is a citizen of the Receiving Country, or

ii) an unmarried individual who habitually resides in the territory of the Receiving Country and who is a citizen thereof,

(hereinafter adoptive parents), provided such adoption and transfer are permitted under the domestic laws of the Parties, and

b) each prospective adoptive parent has met and become acquainted with the child in person before the decision about adoption of the child has been made by the Competent Authority that makes a decision regarding adoption, and has personally participated in the decisionmaking procedure regarding the adoption of the child undertaken by the Competent Authority that makes a decision regarding adoption.

\section{Article 3}

1. This Agreement is concluded for the purposes of ensuring that adoption of children from the United States of America to the Russian Federation and from the Russian Federation to the United States of America takes place with a view to ensuring the protection of the rights and best interests of the child.

2. The Parties shall cooperate with the goal of ensuring that adoption of children in accordance with this Agreement is based on the voluntary actions of the individuals involved in accordance with the Parties' domestic laws. 


\section{ApPendix A (continued)}

3. The Parties shall take appropriate measures provided for by their domestic laws to prevent and suppress illegal activities involving children being adopted, including activities related to deriving illegal income from the adoption, and to kidnapping, substitution, trafficking in children, exploiting child labor, sexual violence against children and sexual exploitation of children, and other activities that are contrary to the objectives of this Agreement.

4. The Parties proceed from the premise that this Agreement covers adoptions where the Country of Origin decides, in accordance with its domestic laws, that it is not possible to arrange for the upbringing of the children in their birth families and:

for the adoption of a child from the United States of America - when due consideration has been given to the possibilities for placement of the child with a family in the United States of America in accordance with its domestic laws;

for the adoption of a child from the Russian Federation - when it does not appear to be possible to settle him or her for upbringing or place him or her with a family that could provide for his or her upbringing or adoption in the Russian Federation in accordance with its domestic laws. 


\section{APPENDIX A (continued)}

9

\section{Article 4}

1. The Executive Bodies shall cooperate with each other and facilitate the interaction of authorities and organizations of the Parties referenced in this Agreement.

2. The Executive Body of each Party (as a Receiving Country) shall provide in writing to the Executive Body of the other Party no less than once a year the following:

a) for the Russian Federation - a list of governmental bodies or organizations of the Russian Federation (with their names and other significant information) that are authorized to perform activities in the field of intercountry adoption in the territory of a foreign state in accordance with the procedure established by the domestic laws of the Russian Federation;

b) for the United States of America - a list of entities (with their names and other significant information) that are authorized in accordance with the domestic laws of the United States of America to perform activities in the field of intercountry adoption in accordance with the Convention on Protection of Children and Co-operation in Respect of Intercountry Adoption of May 29, 1993.

3. Each Party (as a Country of Origin) can establish that authorization to perform activities in the field of intercountry adoption in the territory of the Country of Origin may be issued under this Agreement only to bodies or 


\section{APPENDIX A (continued)}

organizations referenced under Subparagraph 2(a) of this Article, or to those entities referenced under Subparagraph 2(b) of this Article that are non-profit organizations (whichever applies).

The Executive Body of each Party (as a Country of Origin) shall notify the Executive Body of the other Party (as a Receiving Country) in writing of all decisions made in the Country of Origin regarding the issuance to bodies and organizations or entities of the Receiving Country (with their names and other significant information) of authorizations to perform activities in the field of intercountry adoption under this Agreement as soon as this becomes possible after such a decision has been made.

4. The adoption of a child from the Russian Federation, in accordance with this Agreement, shall occur only with the assistance of an Authorized Organization, except as provided for in Paragraph 5 of this Article.

5. The adoption of a child by his or her relatives (who are recognized as such in accordance with the domestic laws of the Country of Origin) and his or her transfer with them to the Receiving Country may occur without the assistance of an Authorized Organization in accordance with the domestic laws of the Parties.

\section{Article 5}

1. The Executive Body of the Country of Origin may establish, in accordance with the procedure provided for by the domestic laws of that country, a 


\section{APPENDIX A (continued)}

requirement for an Authorized Organization to submit the following documents in order to obtain or retain authorization to perform activities in the field of intercountry adoption in the territory of the Country of Origin in accordance with this Agreement:

a) A document confirming the obligations of the Authorized Organization to inform the prospective adoptive parents (including in the case of a dissolution of an adoption and/or placement of the child with another family if these procedures are carried out with the assistance of that organization) of the requirements regarding the adoption procedure in the Country of Origin and of required postadoption actions, such as providing access to a representative of the Authorized Organization to monitor the living conditions and upbringing of the adopted child, submission of reports, and ensuring registration of the child with a consular establishment of the Country of Origin, and a document confirming that the prospective adoptive parents have been informed of these requirements.

b) A document confirming the obligation of the Authorized Organization to monitor in accordance with domestic laws of the Country of Origin the living conditions and upbringing of the children who were adopted with its assistance in accordance with this Agreement and to present the corresponding reports to the Regional Authority of the Country of Origin about the living conditions and upbringing of the adopted child, 


\section{APPENDIX A (continued)}

which contain reliable information about his or her psychological and physical development and adaptation to his or her new family and social environments in the period after the adoption and other information about the adopted child, in accordance with the domestic laws of the Country of Origin;

This document shall also confirm that the monitoring referenced in this subparagraph will be carried out directly by the Authorized Organization at the place of residence of the adoptive parents and the adopted child, or by another organization or individual that is granted the right in accordance with the domestic laws of the Receiving Country to monitor the living conditions and upbringing of adopted children at the place of residence of the adoptive parents and the adopted child, on the basis of a contract made with the Authorized Organization.

c) A document confirming the obligation of the Authorized Organization, in accordance with the domestic laws of the Country of Origin, to provide information about the time of lawful entry to reside in the territory of the Receiving Country, of a child adopted in accordance with this Agreement and about his or her acquisition of citizenship of the Receiving Country.

d) A document confirming the obligation of the Authorized Organization to present information about the registration of the adopted child 


\section{ApPendix A (continued)}

13

with the consular establishment of the Country of Origin by the adoptive parents, in accordance with the domestic laws of the Country of Origin.

e) A document confirming the obligation of the Authorized Organization to send written notice to the Regional Authority of the Country of Origin and the Executive Bodies of the Parties as soon as reasonably possible:

i) of an adoption in which it provided assistance (including an adoption that took place before this Agreement entered into force) that is no longer in the best interests of the child and there is a need for dissolution of the adoption and/or placement of the child with another family;

ii) of the dissolution in the Receiving Country of the adoption in which it provided assistance (including an adoption that took place before this Agreement entered into force), or of the placement of the child with another family;

iii) of new prospective adoptive parents, and about the anticipated timeframe for a decision to be made about the new adoption of the child by the Competent Authority of the Receiving Country that makes a decision regarding adoption; 


\section{ApPEndix A (continued)}

14

iv) of a decision on adoption of the child by the Receiving Country's Competent Authority that makes a decision regarding adoption;

This document shall also confirm the obligation of the Authorized Organization to request the consent of the Executive Body of the Country of Origin to the adoption of the child by the new prospective adoptive parents, and, if such consent or non-consent is available before the decision is made by the Competent Authority of the Receiving Country that makes a decision regarding adoption, to present it to this Competent Authority.

f) A document confirming the obligation of the Authorized Organization to inform in writing the Executive Body of the Country of Origin of the discontinuation by the Authorized Organization of its activities in the territory of the Country of Origin and/or in the territory of the Receiving Country.

g) A document confirming the obligation of another Authorized Organization to fulfill, in accordance with the domestic laws of the Country of Origin and this Agreement, the obligations of an Authorized Organization in the event that the latter ceases its activities in the field of intercountry adoption.

2. The Executive Body of the Country of Origin shall inform the Executive Body of the Receiving Country of cases of non-compliance by an 


\section{ApPendix A (continued)}

15

Authorized Organization with the Country of Origin's domestic laws and any requirements established under Paragraph 1 of this Article. The Receiving Country shall consider such information and take appropriate measures subject to its domestic laws.

3. The Executive Body of the Receiving Country shall inform the Executive Body of the Country of Origin of any substantiated complaints it receives about, or sanctions or other measures it takes against, an Authorized Organization. The Executive Body of the Country of Origin shall consider that information and take appropriate measures subject to its domestic laws.

4. In the event an Authorized Organization is not complying with the domestic laws of the Country of Origin or is not fulfilling the conditions on which it received authorization referenced in Paragraph 1 of this Article, the Executive Body of the Country of Origin may, in accordance with domestic laws, suspend or terminate the authorization to perform activities in the field of intercountry adoption in the territory of the Country of Origin in accordance with this Agreement. Where possible, the Executive Body of the Country of Origin shall send to the Executive Body of the Receiving Country advance written notice of suspension or termination of such authorization. 


\section{ApPEndix A (continued)}

16

\section{APPLICABLE LAWS}

\section{Article 6}

1. The adoption and transfer of a child under this Agreement shall be carried out in accordance with the domestic laws of the Parties and the provisions of this Agreement.

The requirements for prospective adoptive parents shall be determined by the domestic laws of the Parties and the provisions of this Agreement.

2. The conditions under which a child may be adopted, the list of persons, organizations or bodies whose consent is required for the adoption, and also the form of such consent shall be determined by the domestic laws of the Country of Origin.

3. The decision regarding adoption of a child shall be made by the Country of Origin's Competent Authority that makes a decision regarding adoption.

\section{ADOPTION AND TRANSFER PROCEDURES}

\section{Article 7}

Intercountry adoption and transfer of a child from the United States of America to the Russian Federation and from the Russian Federation to the United States of America within the scope of this Agreement shall take place in accordance with the procedures set forth in Articles 8-13 of this Agreement and the domestic laws of the Parties. 


\section{ApPEndix A (continued)}

17

\section{Article 8}

1. Prospective adoptive parents who wish to adopt a child in accordance with this Agreement shall obtain, in accordance with the procedure provided for by the domestic laws of the Receiving Country, a written conclusion about their living conditions, which is issued by a Competent Authority of the Receiving Country that performs an inspection of the living conditions of prospective adoptive parents, and a written conclusion about their suitability and eligibility to adopt a child, which is issued by the Receiving Country's Competent Authority that issues a conclusion regarding the suitability and eligibility of the prospective adoptive parents to adopt a child.

2. The validity period of the conclusions specified in Paragraph 1 of this Article is established by the domestic laws of the Parties.

\section{Article 9}

The Country of Origin's domestic laws determine the following:

a) The procedure for the prospective adoptive parents or an Authorized Organization to submit an application to adopt a child to the Country of Origin's Competent Authority that makes a decision regarding adoption;

b) The procedure by which the appropriate bodies and organizations in the Country of Origin provide information about the child to the prospective adoptive parents; 


\section{APPENDIX A (continued)}

18

c) The procedure for making a decision about adoption by a Competent Authority that makes a decision regarding adoption.

\section{Article 10}

1. After the prospective adoptive parents have personally become acquainted with the child and have expressed their consent to adopt this child but before the decision on adoption of the child is made by the Country of Origin's Competent Authority that makes a decision regarding adoption, the Receiving Country's Competent Authority(ies) that issue(s) a conclusion regarding the suitability and eligibility of prospective adoptive parents to adopt a child and a conclusion regarding the eligibility of prospective adoptive parents to transfer a child to the Receiving Country from the Country of Origin shall, if required by the domestic laws of either Party:

a) Review documentation submitted by the prospective adoptive parents that indicates that:

i) The adoption and transfer are being carried out with the assistance of an Authorized Organization acting in accordance with the requirements specified in Paragraphs 14 of Article 4 of this Agreement;

ii) The prospective adoptive parents have been duly informed of the requirements for completing the process of adoption in accordance with the domestic laws of the Country of Origin; 


\section{ApPEndix A (continued)}

19

b) Confirm that the prospective adoptive parents have received information and undergone all required psycho-social preparation with the assistance of the Authorized Organization or the Competent Authority that performs an inspection of the living conditions of the prospective adoptive parents, in accordance with the procedure established by the domestic laws of the Parties, taking into account the detailed information about the child's social situation and health, and his or her cultural and social environment in the Country of Origin; and that the conclusion regarding the suitability and eligibility of the prospective adoptive parents to adopt a child remains legally valid based on consideration of all information available about the child matched with the prospective adoptive parents, to include:

i) All available information on the social situation of the child, and his or her medical history, and also, if available, all information about the social situation and health of all the child's family members (the Country of Origin shall take all possible measures to ensure access to such information);

ii) A description of any special needs of the child (defined as needs for accommodations, care or medical assistance related to special or disabling physical, mental or emotional conditions); 


\section{APPENDIX A (continued)}

20

iii) The documents that confirm that the child is available to be placed for adoption and that all requirements for obtaining the consent referenced in Paragraph 2 of Article 6 of this Agreement have been fulfilled;

iv) A detailed medical conclusion about the child's current state of health, including the results of a medical evaluation conducted by independent experts, if such an evaluation has been conducted at the initiative of the prospective adoptive parents;

c) Issue a written preliminary conclusion about the eligibility of the prospective adoptive parents to transfer the child who is being adopted from the Country of Origin to the Receiving County, and inform the prospective adoptive parents in writing about the results of the review of the documents presented with a view to the possibility to continue the procedure of adoption and transfer of the child who is being adopted to the Receiving Country.

2. In accordance with its domestic laws, the Country of Origin shall assist in the provision of the information referenced in this Article to the prospective adoptive parents as soon as reasonably possible after the time of receipt of the consent of the prospective adoptive parents to adopt the child.

3. The need for the prospective adoptive parents to complete the procedures specified in Paragraph 1 of this Article may be established by the Executive 


\section{ApPEndix A (continued)}

21

Body of the Country of Origin in accordance with the procedure provided for by the domestic laws of that country.

\section{Article 11}

1. After a decision by the Competent Authority of the Country of Origin that makes a decision regarding adoption of a child enters into legal force, the adoptive parents, if required in accordance with the domestic laws of the Country of Origin, shall be obligated to take the adopted child from the establishment or other place where he or she is staying and to bear full responsibility for the care of the child and for his or her upbringing.

2. In the event that the Competent Authority that issues a conclusion regarding the eligibility of the prospective adoptive parents to transfer the child from the Country of Origin to the Receiving Country denies the eligibility of the adoptive parents to transfer to the Receiving Country a child who has already been adopted, the Executive Body of the Receiving Country shall immediately inform the Executive Body of the Country of Origin thereof, which shall, in accordance with its domestic laws, take measures to protect the rights and best interests of the child.

\section{Article 12}

1. Documents sent by the Executive Bodies to each other shall be in the language of the Party that is sending the document. 


\section{APPENDIX A (continued)}

2. If domestic laws of the Country of Origin require that foreign public documents related to the adoption be authenticated, an "Apostille" shall be placed on them in accordance with the Convention Abolishing the Requirement of Legalisation for Foreign Public Documents of October 5, 1961 , if they fall under its scope. Documents that do not fall under the scope of this Convention shall be certified in accordance with the domestic laws of the Country of Origin. The translation of these documents from one language to another language shall be certified in accordance with the domestic laws of the Country of Origin.

\section{Article 13}

1. The decision on adoption of the child made by the Competent Authority of the Country of Origin that makes a decision regarding adoption shall be recognized by the Receiving Country.

2. A child adopted in accordance with this Agreement shall acquire the citizenship of the Receiving Country in accordance with the procedure established by the domestic laws of the Receiving Country, but no later than upon lawful entry to reside in the territory of the Receiving Country. He or she shall also retain the citizenship of the Country of Origin. Such child shall have the same rights and protections as any other adopted child who has the status of a citizen in the territory of the Receiving Country. 


\section{ApPendix A (continued)}

3. Before the acquisition by the adopted child of the citizenship of the Receiving Country, the Country of Origin shall exercise jurisdiction with respect to this child in accordance with the norms of international law.

\section{COOPERATION AND INFORMATION SHARING}

\section{Article 14}

1. Issues associated with the dissolution of an adoption (including an adoption that took place before the entry into force of this Agreement) and/or the placement of the child with another family are decided in accordance with the applicable domestic laws of the Parties and this Agreement.

2. If the adoption is no longer in the best interests of the child and a need exists to dissolve that adoption and/or place the child with another family in the Receiving Country (including an adoption that took place before this Agreement entered into force), the Executive Bodies of the Parties as soon as reasonably possible shall consult with the goal of agreeing on appropriate measures that the Executive Body of each Party may take to safeguard the interests of the child. This consultation should take place before a decision on a placement of the child with another family is made.

3. With the goal of ensuring the protection of the rights and best interests of the child and creating favorable conditions for his or her harmonious development following the dissolution of an adoption, in the Receiving 


\section{ApPendix A (continued)}

Country measures are taken to place the child with another family that is appropriate for adopting this child.

4. The Executive Body of the Receiving Country shall take appropriate measures with the goal of ensuring that the Regional Authorities of the Receiving Country and/or the Competent Authorities that monitor the living conditions and upbringing of the adopted child:

a) inform the Regional Authority of the Country of Origin and the Executive Bodies of the Country of Origin and the Receiving Country:

i) before a decision on a new adoption, that the adoption is no longer in the best interests of the child and that a need exists to dissolve that adoption and/or place the child with another family (including adoptions that took place before this Agreement entered into force);

ii) about the dissolution of the adoption of a child in the Receiving Country;

iii) about new prospective adoptive parents;

iv) about the completion of the procedure of a new adoption.

b) after the dissolution of an adoption, inform the new prospective adoptive parents about the Country of Origin's requirements concerning the need for required registration of the child with a consular establishment of the Country of Origin, the monitoring of the 


\section{ApPEndix A (continued)}

adopted child's living conditions and upbringing, and the submission of the corresponding reports and information about the child.

5. In the event that the Executive Bodies of the Parties become aware that in the best interests of the child it is essential to provide for the return of the child to the Country of Origin, the Executive Bodies of the Parties shall consult regarding such return and reimbursement of expenses associated therewith.

6. The decision about a new adoption in the territory of the Receiving Country shall be made by the Competent Authority of the Receiving Country that makes a decision regarding adoption in accordance with the domestic laws of the Receiving Country.

\section{Article 15}

1. The Parties shall undertake:

a) to share information of mutual interest about the domestic laws governing the institution of adoption, in particular, pertaining to the requirements for adoptive parents, and statistical data, and other information related to the procedure of adoption;

b) to inform each other regarding the implementation of this Agreement and to take appropriate measures to resolve difficulties that arise during its application. 


\section{APPEndix A (continued)}

26

2. The Executive Body of the Receiving Country shall undertake, subject to its domestic laws, to provide the Executive Body of the Country of Origin upon its written request with information regarding specific cases of adoption, including dissolution of adoption and/or placement of a child with another family. The Executive Body of the Country of Origin, in using the received information, shall ensure its confidentiality in accordance with its domestic laws.

\section{FINAL PROVISIONS}

\section{Article 16}

This Agreement shall not affect the rights and obligations of either Party under other international agreements to which it is party.

\section{Article 17}

1. This Agreement shall enter into force as of the date of the receipt of the final written notification, through diplomatic channels, that the Parties have fulfilled the internal governmental procedures necessary for entry into force of this Agreement.

2. If the Executive Body of the Country of Origin has established a requirement for submitting the documents provided for in Paragraph 1 of Article 5 of this Agreement, bodies and organizations or entities of the Receiving Country which, at the time of entry into force of this Agreement, were performing 


\section{ApPendix A (continued)}

27

activities in the field of intercountry adoption in the territory of the Country of Origin shall, in order to continue carrying out these activities, be obliged to submit these documents to the Executive Body of the Country of Origin within 60 days from the day such a requirement is established. The Executive Body of the Country of Origin shall make a decision as to whether these bodies and organizations or entities will be permitted to continue to perform activities in the field of intercountry adoption in the territory of the Country of Origin, no later than 30 days from the day of submission of the relevant documents in accordance with the procedure established by the domestic laws of the Country of Origin. Until the Executive Body of the Country of Origin makes such a decision, these bodies and organizations or entities may perform activities in the field of intercountry adoption in the territory of the Country of Origin in accordance with the procedure established by the domestic laws of that country.

3. If the Executive Body of the Country of Origin has the authority to make a decision about the issuance of authorization to perform activities in the field of intercountry adoption in the territory of the Country of Origin, bodies and organizations or entities of the Receiving Country which, at the time of entry into force of the Agreement, were not performing such activities may, in order to obtain such authorization, submit an application and properly executed documents to the Executive Body of the Country of Origin at any time after entry into force of this Agreement. In this case, the Executive 


\section{ApPendix A (continued)}

Body of the Country of Origin shall make a decision about the issuance of authorization to perform activities in the field of intercountry adoption in the territory of the Country of Origin no later than 60 days from the day of submission of an application in accordance with the procedure established by the domestic laws of the Country of Origin.

4. Prospective adoptive parents whose documents were registered at a Regional Authority of the Country of Origin at the time of the entry into force of this Agreement shall have the right to complete the adoption procedure in accordance with the procedure which was in place prior to the entry into force of this Agreement. After the entry into force of this Agreement, the provisions in Articles 14 and 15, to the extent that they pertain to cases involving the dissolution of an adoption, will apply to adoptions about which decisions were made prior to the entry into force of this Agreement.

5. This Agreement shall remain in force until one year from the date that one of the Parties informs the other Party through diplomatic channels of its intention to terminate this Agreement.

6. This Agreement may be amended with the written consent of the Parties.

7. Any disputes between the Parties related to the interpretation or application of this Agreement shall be resolved through negotiations between the Executive Bodies of the Parties. If the said Executive Bodies do not reach an agreement, the dispute will be resolved through diplomatic channels. 


\section{Appendix A (continued)}

29

Done at Washington on July 13, 2011, in duplicate, each in the English and Russian languages, both texts being equally authentic.

FOR THE

UNITED STATES OF AMERICA

Hillary Rodhan Chinton
FOR THE

RUSSIAN FEDERATION

labelp 


\section{APPENDIX B (for summary see page 1809)}

\section{FAQs: \\ Bilateral Adoption Agreement with Russia}

October 15,2012

- Why is there a Bilateral Adoption Agreement with Russia?

- When was the Agreement signed?

- When will the Agreement enter into force?

- Does entry into force mean that all provisions of the Agreement will apply as of November 1, 2012?

- What if my case started before entry into force?

- Does this mean that the United States does not want Russia to join The Hague Intercountry Adoption Convention?

- Whom does the Agreement cover?

- Will the Agreement change U.S. visa processing for adopted children?

- What will change in how USCIS processes petitions as a result of this Agreement?

- How will the Agreement affect U.S. adoption service providers' ability to work in Russia?

- Does the Agreement impose any new or more stringent responsibilities on U.S. adoption agencies?

- Is any part of the Agreement effective retroactively?

\section{Q: Why is there a Bilateral Adoption Agreement with Russia?}

Each year, thousands of children find loving, nurturing homes through intercountry adoptions, and the lives of thousands of American families have been enriched by welcoming Russian orphans into their homes. Although the vast majority of U.S. adoptions of Russian children have resulted in positive experiences for everyone involved, there have been several tragic cases. As a result, in April 2010, the U.S. and Russian governments began negotiating the Agreement between the United States of America and the Russian Federation Regarding Cooperation in Adoption of Children (the Agreement) to strengthen procedural safeguards in the adoption process between the United States and Russia.

\section{Q: When was the Agreement signed?}

U.S. Secretary of State Hillary Clinton and Russian Foreign Minister Sergey Lavrov signed the Agreement on July 13, 2011, in Washington, D.C. 


\section{APPEndix B (continued)}

Russia required ratification. The Russian Duma approved the Agreement on July 10, 2012 and the Russian Federation Council approved the Agreement on July 18, 2012. Russian President Vladimir Putin signed the Agreement into law on July 28, 2012 .

\section{Q: When will the Agreement enter into force?}

The Agreement will enter into force on November 1, 2012 following the exchange of diplomatic notes between the U.S. and Russian governments. A copy of the joint statement on the Agreement's entry into force date is available on the website of the U.S. Embassy in Moscow.

\section{Q. Does entry into force mean that all provisions of the Agreement will apply as of November 1, 2012?}

Certain provisions in the Agreement only apply if required by either the United States or the Russian Federation. The provisions regarding new authorization procedures for adoption service providers in Article 5 and pre-processing requirements in Article 10 will not take effect as of November 1, 2012 as these new requirements may only be established following entry into force of the Agreement under Russian law. Please refer to the below Q\&A's for more information on the anticipated timeline for effectiveness of these provisions.

\section{Q: What if my case started before entry into force?}

Prospective adoptive parent(s) whose documents are registered at a Regional Authority in Russia at the time of entry into force are not affected by the terms of the Agreement and may complete the process under the current (pre-Agreement) procedures. The Russian government will compile a list of all prospective adoptive parent(s) whose documents have been registered at the time of entry into force on November 1, 2012.

Prospective adoptive parent(s) working with a non-Hague accredited U.S. adoption service provider whose documents were not registered at a Regional Authority in Russia at the time of entry into force will be required to identify and use the services of a Hague accredited adoption service provider that is authorized to provide services in Russia if they wish to continue with their adoption. That new U.S. Hague accredited adoption service provider will be required to submit 


\section{APPEndix B (continued)}

documentation confirming that they have taken responsibility for working with the family to carry out their obligations in completing the adoption.

\section{Q: Does this mean that the United States does not want Russia to join The Hague Intercountry Adoption Convention?}

No. The United States continues to believe that the Hague Adoption Convention includes the best available procedures for processing intercountry adoptions. The United States continues to encourage Russia to join the Convention. The United States and Russia negotiated the Agreement in order to promote stronger safeguards for adoptive children and parent(s) in the intercountry adoption process between our two countries. The Agreement incorporates several fundamental principles of the Hague Adoption Convention.

\section{Q: Whom does the Agreement cover?}

The Agreement will cover adoptions to and from the United States and Russia. It applies to children up to the age of 18 who are citizens of and habitually resident in one country, and who are adopted in their country of origin by spouses habitually resident in the other country (at least one of whom is a citizen of that country), or by an unmarried individual who habitually resides in and is a citizen of the other country.

Prospective adoptive parent(s) should also be aware that the Agreement only covers adoptions where both spouses, or the individual (if unmarried), have seen and observed the child in person prior to adoption and personally participated in the decision-making procedures by the court issuing the adoption decree.

\section{Q: Will the Agreement change U.S. visa processing for adopted children?}

The Agreement will not significantly affect visa processing for children adopted from Russia. The processing of an adopted child's U.S. visa occurs after the adoption in Russia and the approval of the orphan petition (Form I-600, Petition to Classify Orphan as an Immediate Relative) by U.S. Citizenship and Immigration Services (USCIS). Information on how to adopt from Russia is available on www.adoption. state.gov.

\section{Q: What will change in how USCIS processes petitions as a result of this} Agreement? 


\section{APPENDix B (continued)}

USCIS must ensure that the laws of the country of origin are followed in adjudicating a Form I-600 Petition. At the time of entry into force, the Agreement will have the effect of establishing new legal requirements in Russia, and USCIS will review each petition to ensure that the requirements have been met and the various provisions become effective. The following provides an overview of the most significant changes:

\section{New Independent Adoptions Prohibited}

Effective immediately upon entry into force, the Russian government will no longer permit prospective adoptive parent(s) to begin new independent adoptions (i.e., adoptions where the prospective adoptive parent(s) elect to act on their own behalf without facilitation by an adoption service provider), unless a child is being adopted by a relative. (Relatives, for the purposes of the Agreement, are defined in accordance with Russian law.) After entry into force, USCIS will only be able to approve Form I-600 petitions for independent adoptions grandfathered under Article 17 of the Agreement or for adoptions in which the child is adopted by a relative. Please refer to the Q\&A on adoptions initiated prior to entry into force for more information.

\section{A New Pre-approval Process, Effective on or about March 1, 2013}

The Russian government intends to establish and require a new pre-approval process as described in Article 10 of the Agreement. This process will not be required immediately upon entry into force and will not apply to cases grandfathered under Article 17 of the Agreement.

Under Russian law, the new pre-approval requirement may be established only following entry into force of the Agreement. The Russian government plans to establish this requirement and expects it to become effective on or about March 1, 2013. Following Russia's establishment of a pre-approval requirement, cases involving Russian children being adopted by U.S. prospective adoptive parent(s) whose adoption documents were not registered with the Regional Authority in Russia at the time of entry into force, will be required to undergo a pre-approval process with USCIS after the match but before the Russian adoption is completed. Prospective adoptive parent(s) in these cases will be required to present the Russian courts with a document from USCIS confirming pre-approval to be able to complete the adoption in Russia. 


\section{APPENDix B (continued)}

To implement pre-approval, USCIS will require prospective adoptive parent(s) to file their Form I-600, Petition to Classify an Orphan as an Immediate Relative, before completing the adoption procedures in Russia. USCIS will provide further information on the new filing procedures and how the new process will work as soon as possible, and in advance of March 1, 2013.

\section{Q: How will the Agreement affect U.S. adoption service providers' ability to work in Russia?}

This Agreement will add no additional accreditation or authorization requirements under U.S. law for adoption agencies seeking to provide adoption services in Russia.

Under Russian law, new authorization requirements may be established only following entry into force of the Agreement. The Russian government has assured us that it plans to establish new authorization requirements for adoption service providers and expects them to become effective on or about March 1, 2013. On the date of entry into force, as an interim measure, the Russian government will consider all U.S. adoption service providers which are currently authorized to provide adoption services in Russia and which are U.S. Hague accredited to be authorized (pending implementation of the new authorization requirements). These agencies may continue processing both existing and new cases. The Department of State has agreed to provide the Russian Ministry of Education and Science with the list of U.S. adoption service providers accredited or approved in the United States to provide services under The Hague Adoption Convention, as a means of confirming their Hague accreditation/approval.

Non-Hague accredited U.S. adoption service providers operating in Russia prior to entry into force of the Agreement will not be able to initiate any new cases following November 1, 2012. However, these agencies may continue processing those cases that were registered at a Regional Authority in Russia at the time of entry into force.

Following the Russian government's establishment of new authorization requirements, authorized adoption service providers will have 60 days to submit additional information required under the new regulations to continue providing adoption services in Russia. The Ministry will make a decision about an adoption service provider's authorization within 30 days of receiving the required information. Adoption service providers that do not submit the required documentation for re-authorization within 60-days of Russia's establishment of 


\section{APPEndix B (continued)}

new authorization regulations will lose their authorization to provide adoption services in Russia. These adoption service providers will be allowed to apply for re-authorization after one year.

After entry into force, adoption service providers seeking authorization to begin providing adoption services in Russia will need to meet the requirements under the new authorization procedures. Adoption service providers may apply for authorization to provide adoption services in Russia at any time, but the Ministry of Education and Science encourages new adoption service providers to wait until after the implementation of the new authorization procedures to do so. Under the Agreement, the Ministry of Education and Science must make a decision about a new adoption service provider's authorization within 60 days of receiving the application.

\section{Q: Does the Agreement impose any new or more stringent responsibilities on U.S. adoption agencies?}

Yes, the Agreement allows the Russian government to establish several new or expanded requirements for adoption service providers to receive and maintain authorization to provide adoption services in Russia which are expected to become effective on or about March 1, 2013. Adoption service providers authorized to provide adoption services in Russia will need to meet the requirements established by the Russian Ministry of Education and Science or by Russian law in order to obtain and retain authorization to provide services in relation to intercountry adoptions in Russia. Adoption service providers will be required to submit documentation assuring that they will comply with certain requirements, including the following:

\section{Post-adoption requirements}

- To inform prospective adoptive parent(s) of Russia's adoption procedures and post-adoption reporting requirements (including in the case of a dissolution and/or subsequent placement of a child with another family);

- To monitor the living conditions and upbringing of adopted children as required by the Russian government. The monitoring will have to be carried out at the family's home by the authorized organization's social worker, or by another licensed social worker or organization; 


\section{APPENDIX B (continued)}

- To provide periodic reports following an intercountry adoption to the Russian authorities. The reports will have to contain information about the child's psychological and physical development and adaptation to his/her new life;

- To confirm an adopted child's lawful entry into the United States and the child's acquisition of U.S. citizenship.

\section{Adoption disruption and dissolution requirements}

- To notify Russian authorities and the U.S. Department of State's Office of Children's Issues as soon as reasonably possible if a case in which it provided services (even cases facilitated before the Agreement entered into force) is pending dissolution or has dissolved. The notification may need to include information on any proposed placement or new adoptive family, the expected (or completed) timeframe for the U.S. court's decision (or any decisions reached by the U.S. court). At the same time, for cases still pending a court decision, the authorized organization may be required to request the consent or non-consent of the Russian authorities to the proposed re-adoption, and if a statement is provided by the Russian authorities before the re-adoption decision is made by the court, present the Russian consent or non-consent information to the court for its consideration.

\section{Authorized organization requirements}

- To notify the Russian authorities and transfer any pending cases or postadoption reporting responsibilities to another authorized organization in the event that an authorized organization chooses to cease operating in Russia or loses its authorization to do so.

\section{Q: Is any part of the Agreement effective retroactively?}

Under the Agreement, Russia may impose requirements on adoption service providers regarding the disruption or dissolution of adoptions which they facilitated and which took place prior to entry into force of the Agreement. For example, an authorized organization may be required to report a disruption or dissolution as soon as reasonably possible after it discovers that an adoption may be dissolved or has dissolved, regardless of when the intercountry adoption was completed. 


\section{APPENDIX C (for summary see page 1834)}

Policy Number: 10029.2

FEA Number: 306-112-002b
Office of the Director

v.S. Department of Homeland Security 50012 th Street, SW

Washingtom, D.C. 20536

\section{U.S. Immigration}

and Customs Enforcement
MEMORANDUM FOR;

FROM:

SUBJECT:
OCT 242011

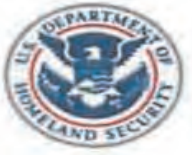

Field Office Directors

Special Agents in Charge Chief Counsel

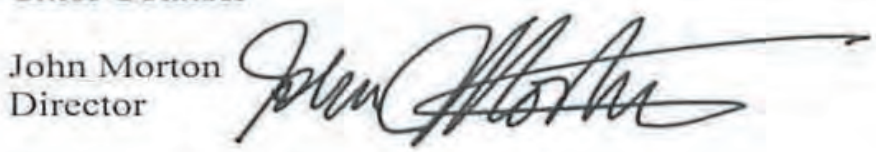

Enforcement Actions at or Focused on Sensitive Locations

\section{Purpose}

This memorandum sets forth Immigration and Customs Enforcement (ICE) policy regarding certain enforcement actions by ICE officers and agents at or focused on sensitive locations. This policy is designed to ensure that these enforcement actions do not occur at nor are focused on sensitive locations such as schools and churches unless (a) exigent circumstances exist, (b) other law enforcement actions have led officers to a sensitive location as described in the "Exceptions to the General Rule" section of this policy memorandum, or (c) prior approval is obtained. This policy supersedes all prior agency policy on this subject. ${ }^{1}$

\section{Definitions}

The enforcement actions covered by this policy are (1) arrests; (2) interviews; (3) searches; and (4) for purposes of immigration enforcement only, surveillance. Actions not covered by this policy include actions such as obtaining records, documents and similar materials from officials or employees, providing notice to officials or employees, serving subpoenas, engaging in Student and Exchange Visitor Program (SEVP) compliance and certification visits, or participating in official functions or community meetings.

The sensitive locations covered by this policy include, but are not limited to, the following:

\footnotetext{
'Memorandum from Julie L. Myers, Assistant Secretary, U.S. Immigration and Customs Enforcement, "Field Guidance on Enforcement Actions or Investigative Activities At or Near Sensitive Community Locations" 10029.1 (July 3, 2008); Memorandum from Marcy M. Forman, Director, Office of Investigations, "Enforcement Actions at Schools" (December 26, 2007); Memorandum from James A. Puleo, Immigration and Naturalization Service (INS) Acting Associate Commissioner, "Enforcement Activities at Schools, Places of Worship, or at funerals or other religious ceremonies" HQ 807-P (May 17, 1993). This policy does not supersede the requirements regarding arrests at sensitive locations put forth in the Violence Against Women Act, see Memorandum from John P. Torres, Director Office of Detention and Removal Operations and Marcy M. Forman, Director, Office of Investigations, "Interim Guidance Relating to Officer Procedure Following Enactment of VAWA 2005 (January 22, 2007).
} 


\section{APPENDIX C (continued)}

Enforcement Actions at or Focused on Sensitive Locations

Page 2

- schools (including pre-schools, primary schools, secondary schools, post-secondary schools up to and including colleges and universities, and other institutions of learning such as vocational or trade schools);

- hospitals;

- churches, synagogues, mosques or other institutions of worship, such as buildings rented for the purpose of religious services;

- the site of a funeral, wedding, or other public religious ceremony; and

- a site during the occurrence of a public demonstration, such as a march, rally or parade.

This is not an exclusive list, and ICE officers and agents shall consult with their supervisors if the location of a planned enforcement operation could reasonably be viewed as being at or near a sensitive location. Supervisors should take extra care when assessing whether a planned enforcement action could reasonably be viewed as causing significant disruption to the normal operations of the sensitive location. ICE employees should also exercise caution. For example, particular care should be exercised with any organization assisting children, pregnant women, victims of crime or abuse, or individuals with significant mental or physical disabilities.

\section{Agency Policy}

\section{General Rule}

Any planned enforcement action at or focused on a sensitive location covered by this policy must have prior approval of one of the following officials: the Assistant Director of Operations, Homeland Security Investigations (HSI); the Executive Associate Director (EAD) of HSI; the Assistant Director for Field Operations, Enforcement and Removal Operations (ERO); or the EAD of ERO. This includes planned enforcement actions at or focused on a sensitive location which is part of a joint case led by another law enforcement agency. ICE will give special consideration to requests for enforcement actions at or near sensitive locations if the only known address of a target is at or near a sensitive location (e.g., a target's only known address is next to a church or across the street from a school).

\section{Exceptions to the General Rule}

This policy is meant to ensure that ICE officers and agents exercise sound judgment when enforcing federal law at or focused on sensitive locations and make substantial efforts to avoid unnecessarily alarming local communities. The policy is not intended to categorically prohibit lawful enforcement operations when there is an immediate need for enforcement action as outlined below. ICE officers and agents may carry out an enforcement action covered by this policy without prior approval from headquarters when one of the following exigent circumstances exists:

- the enforcement action involves a national security or terrorism matter;

- there is an imminent risk of death, violence, or physical harm to any person or property; 


\section{APPENDIX C (continued)}

Enforcement Actions at or Focused on Sensitive Locations

Page 3

- the enforcement action involves the immediate arrest or pursuit of a dangerous felon, terrorist suspect, or any other individual(s) that present an imminent danger to public safety; or

- there is an imminent risk of destruction of evidence material to an ongoing criminal case.

When proceeding with an enforcement action under these extraordinary circumstances, officers and agents must conduct themselves as discretely as possible, consistent with officer and public safety, and make every effort to limit the time at or focused on the sensitive location.

If, in the course of a planned or unplanned enforcement action that is not initiated at or focused on a sensitive location, ICE officers or agents are subsequently led to or near a sensitive location, barring an exigent need for an enforcement action, as provided above, such officers or agents must conduct themselves in a discrete manner, maintain surveillance if no threat to officer safety exists and immediately consult their supervisor prior to taking other enforcement action(s).

\section{Dissemination}

Each Field Office Director, Special Agent in Charge, and Chief Counsel shall ensure that the employees under his or her supervision receive a copy of this policy and adhere to its provisions.

\section{Training}

Each Field Office Director, Special Agent in Charge, and Chief Counsel shall ensure that the employees under his or her supervision are trained (both online and in-person/classroom) annually on enforcement actions at or focused on sensitive locations.

\section{No Private Right of Action}

Nothing in this memorandum is intended to and may not be relied upon to create any right or benefit, substantive or procedural, enforceable at law by any party in any administrative, civil, or criminal matter.

This memorandum provides management guidance to ICE officers exercising discretionary law enforcement functions, and does not affect the statutory authority of ICE officers and agents, nor is it intended to condone violations of federal law at sensitive locations. 


\title{
ApPendix D (for summary see page 1834)
}

\section{Questions and Answers}

U.S. Department of Homeland Security U.S. Citizenship and Immigration Services Public Engagement and Customer Service Directorate

Washington. DC 20529

\section{U.S. Citizenship} and Immigration Services

\section{USCIS-American Immigration Lawyers Association (AILA) Meeting October 9, 2012}

\begin{abstract}
Overview
On October 9, 2012, USCIS hosted an engagement with AILA representatives. USCIS discussed issues related to waivers of inadmissibility, NSEERS, H-1B Visa Cap Registration, the Entrepreneurs in Residence Program, as well as other issues. The information below provides a review of the questions solicited by AILA and the responses provided by USCIS.
\end{abstract}

\section{Stateside Waivers of Inadmissibility for Certain Immediate Relatives of U.S. Citizens}

Question 1a: What is the status of the USCIS review of the comments received in connection with stateside Waivers of Inadmissibility for certain immediate relatives of U.S. citizens?

Response: USCIS has received and reviewed all the comments received in connection with the Proposed Rule on Provisional Unlawful Presence Waivers. USCIS and DHS are working on a final rule for publication in the Federal Register.

Question 1b: What is the anticipated timeline for implementation of this program?

Response: The final rule is expected to be published in the Federal Register by the end of this calendar year.

Question 1c: What steps is the Service taking to ensure that provisional waivers are consistently adjudicated to the same standards now being used for centralized filing of waivers?

Response: USCIS is preparing field guidance and will conduct training for personnel who will be adjudicating the provisional unlawful presence waivers. The standards used for adjudicating the provisional unlawful presence waivers will parallel the standards now being used for the centralized Form I-601 waivers. USCIS also will update the existing training programs to more precisely address adjudication issues specific to the provisional unlawful presence waiver process.

\section{NSEERS}

USCIS is currently holding cases in which it appears that the applicant has violated the National Security Entry-Exit Registration System (NSEERS) registration requirement. On April 27, 2011, the Department of Homeland Security announced the removal of the list of countries whose nationals have been subject to registration under NSEERS (AILA Doc. No. 11042769). ${ }^{1}$ On April 16, 2012, USCIS released a memorandum providing guidance on individuals previously subject to NSEERS and it was our

\footnotetext{
${ }^{1}$ Schlanger Memo on the Elimination of NSEERS Country Designations, AILA Doc. No. 11042769,
} http://www.aila.org/content/default.aspx?docid=35229 


\section{APPENDIX D (continued)}

understanding that additional guidance was scheduled to be issued in June 2012 (AILA Doc. No. $12042661)^{2}$

Question 2a: What is the status of the USCIS guidance on how to process cases in which the applicants were subject to NSEERS, but did not register?

Response: USCIS has issued revised guidance on NSEERS consistent with the DHS policy.

Question 2b: Upon issuance of this guidance, what steps will applicants with pending petitions/applications need to take with USCIS to ensure the petition/application will be processed or will USCIS affirmatively return such pending petitions/applications to the adjudications queue for processing? Response: USCIS will automatically process these applications and petitions. No action is needed on the part of the applicant or petitioner.

\section{H-1B Visa Cap Registration}

Question 3: Please provide an update on the proposed H-1B Visa Cap Registration program, including any anticipated start date and changes to the electronic program from the initial proposed rule (AILA Doc. No. 11030261). ${ }^{3}$ AILA renews its concerns contained in the May 2, 2011, comment and would welcome an opportunity to work closely on any new proposed version of the program (AILA Doc. No. 11050267). ${ }^{4}$

Response: On October 20, 2011, Director Mayorkas issued a message stating that USCIS was postponing issuing a final rule. Instead, USCIS continues to assess how the proposed rule's objectives can be achieved within the framework of our ongoing Transformation initiative.

\section{Elimination of Form I-94 and Elimination of Admission Stamps}

On August 2012, U.S. Customs and Border Protection confirmed that CBP no longer places admission stamps on Form I-20 and Form DS-2019 (AILA Doc. Nos. 12082242 \& 12090543). ${ }^{5}$ AILA understands that some staff at certain benefit granting agencies (for example, motor vehicle agencies) look for a stamp on these documents before granting a benefit and the absence of the stamp has created unintended consequences. We anticipate similar problems when CBP implements the elimination of the I-94 entirely.

Question 4a: Can you explain the efforts that USCIS is making to reach out to the other agencies on this issue, and to prepare for the elimination of the I-94? Please identify the agencies USCIS has notified. Response: CBP's I-94 initiative is to automate, not eliminate, Form I-94. USCIS has held several outreach events to hear agencies' concerns regarding Form I-94 automation. In February 2012, the SAVE program announced I-94 automation and hosted a national stakeholder engagement with CBP on this topic. In addition, USCIS hosted training webinars for SAVE customer agencies, followed by a joint USCIS and CBP conference call with departments of motor vehicles and the American Association of Motor Vehicle Administrators, and dissemination of I-94 frequently asked questions to SAVE customer agencies. To expand on these outreach efforts, in April 2012, the USCIS Public Engagement Division

\footnotetext{
${ }^{2}$ DHS Releases Guidance on Treatment of Individuals Previously Subject to NSEERS, AILA Doc No. 12042661, $\underline{\text { http://www.aila.org/content/default.aspx?docid }=39378}$

376 FR 11686, 3/3/11, DHS Proposed H-1B Registration Rule for Cap-Subject Petitions, Request for Comments, AILA Doc. No. 11030261 , http://www.aila.org/content/default.aspx?docid=34726

${ }^{4}$ All. A Comments on Proposed H-1B Registration System, AILA Doc. No. 11050267 ,

http://www.aila.org/content/default.aspx?docid=35269

${ }^{5}$ CBP Issues Memo on Admissions Stamp on Form I-20, AILA Doc. No. 12082242,

http://www.aila.org/content/default.aspx?docid=41005; CBP Discontimues Stamps on I-20 Form, AILA Doc. No. 12090543, http://www.aila.org/content/default.aspx?docid=41170, http://www.cbp.gov/xp/cgov/travel/travel_news/cbp_i20_stamp.xml
} 


\section{APPENDIX D (continued)}

with CBP discussed I-94 automation at a quarterly intergovernmental affairs teleconference. Also in April, USCIS and CBP had individual conference calls with DMVs in North Carolina and South Carolina, California, New York, Georgia, and Florida as well as the California Department of Health Services, Department of Health and Human Services (Federal), and the Department of Education (Federal). In addition, USCIS and CBP participated in the July 2012 Student Exchange Visitor Program's (SEVP) Local Town Hall Meeting to discuss I-94 automation with local university officials. Most recently, in August 2012, USCIS disseminated an announcement reminding agencies to use the Unexpired Foreign Passport in lieu of the I-94 when appropriate, reminding agencies that I-94 automation by CBP will occur at a future date.

Question 4b: What, if anything, is being done by USCIS to prepare for this process in connection with I9 verification, and will instructions be revised to take this into account?

Response: USCIS proposed revisions to Form I-9, published on March 27, 2012, and updated on August 22, 2012 (correction published on September 14, 2012). The revisions retain Form I-94 (AILA Doc. No. 12032720). ${ }^{6}$ In addition to formatting changes, the proposed revisions to Form I-9 take into account CBP's I-94 automation initiative by adding space in Section 1 for the employee to note his or her foreign passport information. This information can be used to obtain admission information just as in the case of Form I-94. No changes were made to the documents on the List of Acceptable Documents. It was determined that CBP's I-94 automation initiative will not require changes to this list.

Question 4c: AILA is concerned that the implementation of the new I-9 should be accompanied with a lengthy roll-out and transition. Will USCIS consider a 180 day transition to outreach can be conducted to the millions of affected employers?

Response: Currently, USCIS is awaiting OMB approval of the revised form. Once approved, USCIS is planning to conduct vigorous public outreach prior to posting the revised form for use. USCIS will take your suggestion regarding a transition period under advisement.

Inaccurate Processing Times and Processing Delays

During the March 29, 2012, meeting with AILA, USCIS representatives stated that they would do further investigation as to the source of the discrepancy between the processing times listed online and the "actual" processing times that are provided to National Customer Service Center (NCSC) information officers (AILA Doc. No. 12033045). ${ }^{7}$

Question 5a: What did your investigations reveal as the source of the discrepancy?

Response: Investigations revealed that our Texas Service Center had inadvertently been processing cases out of receipt order thereby deviating from our standard first-in / first-out policy. This processing error is believed to be the source of the customer complaint that was raised during the March 29 meeting. The processing time calculation was confirmed to be correct, and it is important to note that the processing times posted on the web are not representative of real-time active case status (i.e., an aging report), but are an approximation of the average time that an office is taking to complete the processing of cases received.

\footnotetext{
${ }^{6} 77$ FR 18256 (3/27/12) and 77 FR 50710 (8/22/12), USCIS Comment Request of Form I-9, AILA Doc. No. 12032720, http://www.aila.org/content/default.aspx?docid $=39073$

${ }^{7}$ AllA/USCIS Liaison Meeting Q \& As (03/29/2012), Q 1(c)(iii), posted on AILA InfoNet at AILA Doc No. 12033045, http://www.aila.org/content/default.aspx?docid $=39104$, http://www.uscis.gov/USCIS/Outreach/Notes\%20from\%20Previous\%20Engagements/2012/March\%202012/AILA_Liaison_Co mmittee_agenda_3-29-12_FINAL.pdf
} 


\section{APPENDIX D (continued)}

USCIS calculated processing times are simply a reflection of the number of months of application/petition receipts that an office's inventory of pending cases represents. The 4.1 month processing time reported for the TSC indicates that the inventory of pending cases was equivalent to the number of cases that the center had received over the past 4.1 months. We are unable to say, however, that all of the cases reported within the pending inventory were no older than 4.1 months. The fact that the TSC had inadvertently began processing cases out of receipt order provides important information to suggest that the TSC was very likely holding cases that were much older than the 4.1 month processing time displayed on the web page, and the source of the customer dissatisfaction communicated.

USCIS expresses the online processing times based on workload processing goals. If USCIS is processing a particular type of petition in less time than the processing goal, the public sees the processing times expressed in months. However, if the Service Center is taking longer than the processing goal to handle the form type in question, USCIS will post the filing date of the oldest pending case the Service Center has to process as of the date the website chart was last updated.

In calculating the processing times, USCIS only calculates the time a case is considered to be actively pending with USCIS. The processing time is calculated based on the time it takes USCIS to adjudicate the case. It does not take into account the time USCIS is waiting for action by the Petitioner. For example, if a Petitioner has not presented sufficient evidence to establish eligibility for the classification sought in its petition, rather than denying a case, USCIS may issue a Request for Further Evidence (RFE) or a Notice of Intent to Deny (NOID) to allow the petitioner an opportunity to supplement its filing. When USCIS issues an RFE, a petitioner is given 12 weeks ( 84 days) to respond. Because the response time varies and depends upon each petitioner, USCIS does not factor the time it is waiting for action from the petitioner into its processing times.

Question 5b: The new processing times charts reveal that processing times for cap-subject $H-1 B$ petitions is over four months. What steps is USCIS making to processes these cases so that cap-gap beneficiaries can continue to be employed on and after October $1^{\text {st }}$, and so those beneficiaries with consular notification have sufficient time to be processed for visas and admission by their requested October $1^{\text {st }}$ start dates?

Response: USCIS understands AILA's concerns about the processing times for cap-subject H-1B petitions, including cap gap and consular notification cases. Service Center Operations has made the adjudication of these cases by October $1^{\text {st }}$ a top priority and even authorized overtime to the Service Centers for this purpose. Our Service Centers are doing their best to adjudicate these cases as soon as possible.

Question 5c: On August 17, 2012, USCIS posted the most recent processing time reports; however, the data indicates that the information is current as of June $30,2012 .^{8}$ This means that the data was already 45 days old when published. Are there any efforts underway to gather and report the data in a more timely manner, and if so, when does USCIS expect to be able to publish this more timely data?

Response: As noted in previous communications with AILA, the USCIS Office of Performance and Quality (OPQ) has been working with the Office of Information Technology to develop a new Enterprise Performance Analysis System (ePAS) to replace its legacy reporting system that relies upon the manual collection and self-reporting of monthly performance data. The current performance reporting process is cumbersome and time consuming, and has long impacted USCIS' ability to post processing times earlier than 45 days after the close of the reporting month. The ePAS system continues to offer the greatest

${ }^{8}$ Processing Time Reports, www.aila.org/processingtimes, https://egov.uscis.gov/cris/processTimesDisplayInit.do 


\section{APPENDIX D (continued)}

immediate opportunity for near real time reporting of processing time information. However, the system continues to undergo development and testing, and implementation is now planned for early FY2013. In the meantime, the OPQ has been working to identify options for improving the timeliness of processing time reporting. One such option identified involves using initial performance data received from field components to calculate processing times, rather than waiting until all internal data review and validation efforts are completed. A study of initial and final data over the past several months has identified that very few changes impacting processing time calculations were being made to the initial data following receipt from the field components. Therefore, switching to the use of initial data to calculate processing times is expected to immediately reduce the current 45 -day posting delay by $33 \%$, or 15 -days. By using initial data USCIS will be able to post processing time information 30 days following the end of the reporting month, thereby providing customers with information that is more current and useful. USCIS will be implementing this process change starting with the posting of August 2012 processing times, which were posted on October 4, 2012. This process change will be instituted and maintained until such time that the ePAS system is implemented and system data is available to further improve the timeliness of posting processing time information to the USCIS website.

Entrepreneurs in Residence (EIR) Progr am

Question 6a: On May 18, 2012, USCIS released in full certain documents related to USCIS fraud investigations in the H-1B program (AILA Doc. No. 12052252). ${ }^{9}$ Many of the criteria that USCIS considers to be indicators of fraud, such as companies in operation for less than ten years, companies with less than 25 employees, and companies with less than \$10 Million annual revenue are characteristics commonly shared by small and emerging businesses and entrepreneurial ventures. Given the priority the administration has given to encourage immigrant entrepreneurship, what steps has USCIS taken to ensure that these criteria are not being used to effectively contradict the Administration's policy?

Response: USCIS is reviewing its current guidance on this issue.

Question 6b: How has the Entrepreneurs in Residence program informed USCIS thinking in processing petitions filed by entrepreneurs?

Response: The EIR initiative has provided USCIS with a greater understanding about the startup landscape which should result in more efficient and effective processing of petitions filed by startup and small companies.

Specifically, the EIR team explored additional forms of evidence that the agency has not traditionally asked for, and that entrepreneurs may be able to provide, to help determine eligibility for certain nonimmigrant visa classifications. The EIR team also developed and deployed a training workshop for USCIS employment-based immigration officers at the Vermont and California Service Centers that focused on entrepreneurs and the environment for startup companies and early-stage innovations. A smaller group of officers at both the VSC and CSC, who have been designated to review all startup and entrepreneur petitions, received additional document-specific training and participated in case study workshops with the EIR team.

In addition to internal education, the EIR team is developing a new web portal that aims to close the information gap between USCIS and the entrepreneurial community. This resource aims to provide foreign entrepreneurs with a high level overview of the nonimmigrant visa process, a summary of key

\footnotetext{
${ }^{9}$ USCIS Memo in Response to H-1B Benefit Fraud and Compliance Assessment Findings, AILA Doc. No. 12052252,
} http://www.aila.org/content/default.aspx?docid $=39755$ 


\section{APPENDIX D (continued)}

requirements for nonimmigrant visa categories, and filing tips to help them better understand the evidentiary requirements for nonimmigrant visa categories.

Question 6c: AILA remains concerned that the interpretation of the employer-employee relationship advanced by USCIS in the January 8, 2010, memorandum "Determining Employer-Employee Relationship for Adjudication of H-1B Petitions, Including Third-Party Site Placements," applied in not only the adjudication of $\mathrm{H}-1 \mathrm{~B}$ petitions, but also in I-140 petitions, impedes opportunities for entrepreneurs and small and start-up businesses (AILA Doc. No. 10011363). ${ }^{10}$ The requirements to establish the existence of an employer-employee relationship set out in the memo are felt particularly by entrepreneurs seeking to have corporations that they established petition on their behalf. What steps has USCIS taken to ensure that the adjudication of petitions for company owners are in line with the goals of the Entrepreneurs in Residence Program and the historical legal precedent on whether a corporation can petition for a shareholder?

Response: The EIR team evaluated the challenges and limitations faced by entrepreneurs in filing for and obtaining $\mathrm{H}-1 \mathrm{~B}$ visas enabling them to work for their own or other startup companies. USCIS continues to review these issues as they relate to current guidance on the employer-employee relationship.

Question 6d: Another area of adjudications that seems to be running contrary to the goals of the Entrepreneur in Residence Program continues to be denial of H-1B petitions for Market Research Analysts. For example, adjudicators often base the decision to deny on the conclusion that a start-up company or a small business does not require an individual in the specialty occupation of a Market Research Analyst when in today's increasingly complex marketplace, it is increasingly likely that an entrepreneurial venture or small company will be using a market Research Analyst to perform sophisticated market analysis. Can USCIS provide some insight into how the lessons of the EIR program might have informed adjudications in this area?

Response: As discussed above, the EIR team developed and deployed an intensive training workshop for USCIS employment-based immigration officers at the Vermont and California Service Centers. The training covers a variety of topics such as the history and anatomy of a startup, business fundamentals, stages of a startup, and funding and sources of capital. Among other things, the training aims to provide officers with a better understanding of the typical roles and responsibilities within the context of early stage startup companies.

Question 6e: Entrepreneurs and other H-1B petitioners continue to see denials of H-1B petitions where the "highly specialized knowledge" required for a specialty occupation may be obtained in a variety of ways and through a variety of formal academic programs or majors, and where a degree in one of several academic fields may provide the appropriate academic background required for entry in the occupation. This issue was raised during the March 29, 2012, meeting between AILA and USCIS HQ, during which AILA provided USCIS with several specific case examples (AILA Doc. No. 12033045). ${ }^{11}$ An April 4, 2012 memorandum from AILA further elaborates on concerns regarding

\footnotetext{
${ }^{10}$ USCIS Memo on Determining Employer-Employee Relationship for Adjudication of H-1B Petitions, Including Third-Party Site Placements, AILA Doc. No. 10011363, http:/www.aila.org/content/default.aspx?docid=30950; Strategic Staffing IT, Inc. $v$. Mayorkas (No. 4:11-cv-15709, U.S.D.C, E.D., Mich).

${ }^{11}$ All A/USCIS Liaison Meeting $Q \&$ As (03/29/2012), Q 2(b), posted on AILA InfoNet at AILA Doc No. 12033045,

http://www.aila.org/content/default.aspx?docid $=39104$,

http://www.uscis.gov/USCIS/Outreach/Notes\%20from\%20Previous\%20Engagements/2012/March\%202012/AILA_Liaison_Co mmittee_agenda_3-29-12_FINAL.pdf
} 


\section{APPENDIX D (continued)}

USCIS restrictive interpretation of "specialty occupation" and "body of highly specialized knowledge" in $\mathrm{H}-1 \mathrm{~B}$ petitions and asks USCIS to take steps to bring adjudications in line with the statute and regulations (AILA Doc. No. 12040451). ${ }^{12}$ Unfortunately, there has been little noticeable change in adjudications, and petitioners still receive denials where study in one of several academic fields followed by a degree is held to be evidence that the position is not a "specialty occupation" and that the beneficiary is not qualified. Please update us on steps that USCIS has taken to bring $\mathrm{H}-1 \mathrm{~B}$ adjudications in line with respect to the interpretation of the terms "specialty occupation" and "body of highly specialized knowledge."

Response: USCIS is currently reviewing the issues raised in AILA's April 4, 2012 memorandum related to the interpretation of "specialty occupation" and "body of highly specialized knowledge."

Question 6f: Statistics released by USCIS and a recent study by the National Foundation for American Policy have shown that the rates of requests for evidence and denials for petitions in the L-1B classification have increased dramatically and that the standard for what qualifies under the L-1B classification has been severely limited (AILA Doc. Nos. $12082954 \& 12020964$ ). ${ }^{13}$ This has been a particular burden on new and emerging companies in the U.S. The increase in requests for evidence and denials has happened even as practitioners have been overly cautious in recommending the L-1B classification to their clients. On January 24, 2012, AILA submitted a memorandum to USCIS on the current interpretation of "specialized knowledge" (AILA Doc. No. 12012560). ${ }^{14}$ Please update us on USCIS' review of the memorandum and on the long-promised L-1B memorandum. (POLICY)

Response: USCIS continues to review the issues related to the interpretation of "specialized knowledge," and is considering AILA's memorandum of January 24, 2012 as part of this review.

Question 6g: One particularly problematic interpretation for foreign entrepreneurs starting or maintaining a new office in the United States is the bifurcation of the analysis of the definition of "specialized knowledge" into (a) whether the beneficiary has specialized knowledge and (b) whether the position requires specialized knowledge. This interpretation is also illustrated in the attached example. The regulation requires the Petitioner to submit "(ii) Evidence that the alien will be employed in a . . specialized knowledge capacity . .."15 INA 214(c)(2)(B) defines "specialized knowledge" as follows: "For the purposes of section $101(\mathrm{a})(15)(\mathrm{L})$, an alien is considered to be serving in a capacity involving specialized knowledge . . . if the alien has a special knowledge of the company product and its application in international markets or has an advanced level of knowledge of processes and procedures of the company." The use of the term "involving" rather than "requiring" when discussing specialized knowledge capacity also speaks to a unified definition. This interpretation has been followed historically

\footnotetext{
${ }^{12}$ AllA Memorandum to USCIS Interprets H-1B "Specialty Occupation," AILA Doc. No. 12040451, http://www.aila.org/content/default.aspx?docid=39153

${ }^{13}$ NFAP Report on High Denial Rates of L-1 and H-1B Petitions at USCIS, National Foundation For American Policy, NFAP Policy Brief, February 2012, AILA Doc. No. 12020964, http://www.nfap.com/pdf/NFAP_Policy_Brief.USCIS_and_Denial_Rates_of_L1_and_H\%201B_Petitions.February2012.pdf: USCIS L-1B Performance Data by Approvals and Denials, AILA Doc. No. 12082954, http://www.aila.org/content/default.aspx?docid=41107, http://www.uscis.gov/USCIS/Resources/Reports\%20and\%20Studies/Immigration\%20Forms\%20Data/Employment-based/i-1291-1b-performance.pdf

${ }^{14}$ AIIAM Memorandum to USCIS Interprets L-1B "Specialized Knowledge," AILA Doc. No. 12012560, http://www.aila.org/content/default.aspx?docid=38301

${ }^{15} 8$ CFR $\$ 214.2(1)(3)$
} 


\section{APPENDIX D (continued)}

as well. ${ }^{16}$ Inappropriately bifurcating the analysis particularly works a hardship on new offices of a foreign company. AILA requests that the service centers amend their analysis to comport with the statutory and regulatory definition of "specialized knowledge" in this regard. (POLICY)

Response: USCIS appreciates AILA's request and will consider this request within our review of the interpretation of "specialized knowledge."

\section{Adam Walsh Act}

Recently, the Board of Immigration Appeals (BIA) has begun remanding denied I-130 petitions based on Adam Walsh Act (AWA) determinations back to the USCIS for clarification on various legal issues. These cases remain pending without resolution. The AWA raises many legal issues which remain unresolved and on which the public needs clarification. Please let us know if USCIS has formulated a response to the following questions posed by the BIA on remand and/or if we can expect further guidance on these issues in the near future.

Question 7a: Whether the government has the burden of proving that the petitioner's conviction is for a "specified offense" against a minor under section 111 of the AWA?

Question 7b: Whether the categorical and modified categorical approach should be used in making the foregoing determination?

Question 7c: If the petitioner is found to have been convicted of a "specified offense" against a minor, is there a rebuttable presumption that the petitioner will post a risk to the beneficiary or a derivative beneficiary? Further, what is the basis for the presumption and does it only apply to visa petitions where the principal beneficiary or a derivative beneficiary is a minor?

Question 7d: If the petitioner is found to have been convicted of a "specified offense" against a minor, whether and under what authority, the government applies a "beyond a reasonable doubt" standard in determining - as a matter of discretion - if petitioner is a risk to the safety or well-being of the principal or a derivative beneficiary.

Question 7e: Whether the Director must explain the rationale for his/her conclusion that the petitioner poses a risk to the principal beneficiary or a derivative beneficiary?

Question 7f: If the Director denies a visa petition under the AWA and the petitioner files an appeal to the BIA, does the BIA have jurisdiction to review the question of whether the Secretary applied the correct standard in determining whether a petitioner has shown he or she is not a risk to the principal beneficiary or any derivative beneficiary?

Question 7g: What is USCIS's position on the nature and scope of the BIA's jurisdiction over other aspects of the appeal?

Response: USCIS has submitted a filing to the Board setting out its current positions on these points. We look forward to the Board's decision in that case, which we anticipate will result in further guidance on these issues.

\footnotetext{
${ }^{16}$ Matter of Raulin, 13 I\&N Dec. 618 (Reg. Comm. 1970); Matter of Vaillancourt, 13 I\&N Dec. 654 (Reg. Comm. 1970); Matter of LeBlanc, 13 I\&N Dec. 816 (Reg. Comm. 1971); Matter of Colley, 18 I\&N Dec. 117 (Comm. 1981); and Matter of Penner, 18 I\&N Dec. 49 (Comm. 1982).
} 


\section{APPENDIX D (continued)}

I-140 Ability to Pay Issues

Question 8: AILA has received reports of RFEs for large corporations with regard to the ability to pay where the companies file consolidated returns or consolidated financial statements. Both the Internal Revenue Act and the Securities and Exchange Act permit consolidated filings for a parent company and the wholly-owned subsidiaries. However, USCIS has stated in the RFEs issued to these employers that "the annual report does not prove the ability to pay because the petitioner's parent has no obligation to pay the salary offered to the beneficiary by its subsidiary." It would appear that a consolidated return or audited financial statement that shows the ability of the parent company to pay the salary would meet the burden of proof of the ability to pay by a preponderance of the evidence. Please confirm that consolidated returns and audited financial statements for a parent company and the wholly-owned subsidiaries would meet the burden of proof to show an ability to pay by a preponderance of the evidence. Response: Each consolidated financial statement is evaluated on a case by case basis under the preponderance of evidence standard to determine whether the petitioner has the ability to pay the proffered wage. To the extent the consolidated statement reports financial information about the petitioner, the adjudicator can use that information to evaluate the petitioner's ability to pay the proffered wage.

\section{Schedule A, Group I EB-2 filings for Physical Therapists}

Question 9: Members have raised concerns about Texas Service Center (TSC) and Nebraska Service Center (NSC) denials of Schedule A, Group I EB-2 filings for certain foreign physical therapists. Typically, these filings include evidence that the beneficiary has the equivalent of a master's degree in physical therapy as determined by the Foreign Credentialing Commission on Physical Therapy (FCCPT). FCCPT issues more than one type of evaluation. The evaluations submitted in these cases are issued not for licensure purposes but solely for the purpose of demonstrating equivalency to U.S. educational coursework and analyze only credits earned consistent with national standards.

By way of background, FCCPT is an agency that authenticates, verifies and evaluates educational documents of foreign physical therapists. FCCPT is authorized to issue the visa screen required by the USCIS and it performs a comparison of an educational curriculum to the U.S. educational standard using the standardized Coursework Tool for Foreign Educated Physical Therapists (CWT), developed by the Commission on Accreditation in Physical Therapy Education, (CAPTE); the only agency licensed to accredit Physical Therapy education programs in the U.S. Each version of the CWT reflects the minimum educational requirements for substantial equivalence to a U.S. first professional degree in physical therapy at the time of graduation.

Despite the recognized expertise of FCCPT as well as their application of strict standards for educational evaluations, USCIS has been denying EB-2 petitions even though FCCPT has concluded, after a detailed analysis of all coursework and credits, that the degree is equivalent to a U.S. Master's degree. Please confirm that a determination by the FCCPT and of the various state licensing authorities that the foreign credentials of a first professional degree in physical therapy is the equivalent if an advanced degree from an accredited U.S. university would meet the burden of proof by a preponderance of the evidence that an Immigrant Visa petition for a physical therapist is entitled to EB-2 classification.

Response: USCIS considers FCCPT evaluations. However, these evaluations are not binding on USCIS. USCIS will continue adjudicating these filings on a case by case basis. Whether the physical therapists are indeed eligible for EB-2 classification depends on the individual facts of each case. For EB-2 classification as a member of the professions holding an advanced degree, USCIS determines whether a beneficiary has an advanced degree, as defined in 8 CFR 204.5(k)(2):

- a U.S. academic or professional degree, or a foreign equivalent degree above that of baccalaureate; or

- a U.S. baccalaureate degree, or a foreign equivalent degree, followed by five years of progressive experience in the specialty, which is considered the equivalent of a master's 


\section{APPENDIX D (continued)}

degree. NOTE: An alien who does not possess at least a U.S. baccalaureate degree or a foreign equivalent degree will be ineligible for this classification.

\section{Issuance of NTAs in Denied Tem porary Protected Status (TPS) Cases}

Question 10: The BIA has held that an applicant for TPS may obtain de novo review of her TPS application before an immigration judge in removal proceedings. ${ }^{17}$ More recently, in Matter of Figeuroa, the BIA held that the immigration judge may consider any material and relevant evidence in the proceedings regardless of whether it was submitted to USCIS. ${ }^{18}$

In the November 7, 2011, Notice to Appear (NTA) memo, USCIS indicated that NTAs for denied TPS cases will continue to follow the procedures under the September 12, 2003, Yates Memo (AILA Doc. Nos. $11110830 \& 03100240) .{ }^{19}$ That memo, in turn, discusses issuing NTAs in denied TPS cases where the denial or withdrawal constitutes a ground of deportability or excludability. The 2003 memo indicates that the regulations require the issuance of a charging document when the basis for a TPS denial is a ground of deportability or excludability. ${ }^{20}$ The November 7,2011 , memo read in conjunction with the September 12, 2003, memo seems to indicate that USCIS will not issue charging documents for denied TPS cases where the denial is not based on a ground of deportability or excludability.

Where an alien denied TPS wishes to have the application reviewed by an immigration judge, and thus, wishes to have an NTA issued and filed with the immigration court, by what process should that be done? Should the request be in writing to the service center, to a field office, or to a district office? Since the denial often results in denied work authorization, how can an applicant in such circumstances ensure that there will not be adverse consequences for purposes of employment and that the NTA will be promptly issued?

Response: Thank you for raising this issue. It is currently under consideration. In general, if an individual is found ineligible for TPS, USCIS will issue a denial notice with appeal rights. However, a charging document (NTA) will be issued if the denial is based on a ground of ineligibility under 8 CFR 244.4 or inadmissibility under 8 CFR 244.3(c). See 8 CFR 244.10(c). This also applies to withdrawals pursuant to 8 CFR 244.14(b)(3). Therefore, USCIS will not issue an NTA if the denial or withdrawal is for a reason other than ineligibility under 8 CFR 244.4 or inadmissibility under 8 CFR 244.3(c).

\section{Questions on the Cases in Removal and Applications for Benefits}

AILA appreciates the efforts of DHS to resolve issues in this area, and efforts by USCIS have had an extremely positive effect on AILA members and the lives of their clients. AILA hopes that we can see similar progress in the following areas:

Question 11a: An individual in proceedings (typically an immediate relative) has an I-130 filed on his or her behalf. At the present time, the I-130 is adjudicated by USCIS, but not transferred to the National Visa Center (NVC) for processing until Immigration and Custom Enforcement (ICE) releases the application. For respondents who intend to depart the country voluntarily and pursue consular processing

\footnotetext{
${ }^{17}$ Matter of Lopez-Aldana, 25 I\&N Dec. 49 (BIA 2009), 8 C.F.R. $\$ \$ 244.17$ (B) and 1244.18(b).

${ }^{18}$ Matter of Figeuroa, 25 I\&N Dec. 596 (BIA 2011).

${ }^{19}$ USCIS Revises Guidance on the Referral of Cases and Issuance of NTAs in Cases Involving Inadmissible and Removable Individuals, AILA Doc. No. 11110830 , www.aila.org/content/default.aspx?docid=37578; USCIS Guidelines for Service Center Issuance of NTAs, AILA Doc. No. 03100240, www.aila.org/content/default.aspx?docid $=9447$

${ }^{20} 8$ CFR $244.10(\mathrm{c})(1)$ and $244.14(\mathrm{~b})(3)$.
} 


\section{APPENDIX D (continued)}

on their approved petition, the ICE hold slows down the adjudication process and appears to add little in the way of administrative efficiency or docket control. Would USCIS consider a process whereby such applicants can request a transfer of the approved I-130 to the NVC so that the beneficiary could more effectively coordinate his or her visa process with the removal process?

Response: If a Service Center receives an I- 130 spousal petition and the beneficiary is in removal proceedings, the Service Centers relocate the petition to the District Office if INA 204(g) applies. If INA 204(g) does not apply, and the Service Center has no other reason to believe the petition should be adjudicated at a District Office, the Service Center adjudicates the petition and, if approved, sends the petition to the National Visa Center. The Service Centers do not hold on to the petitions until "ICE releases the application."

Question 11b: A beneficiary of an approved I-130 who is in proceedings and who is eligible to adjust status has the option of moving to terminate proceedings to request adjudication of the adjustment application before USCIS. In cases where the I-485 has already been filed with the Immigration Judge, the application must be returned to USCIS. While the process is smooth in some jurisdictions, applicants in other jurisdictions experience lengthy delays before the application can be adjudicated. Would the agency consider directing field offices to adopt uniform procedures to ensure that consideration of these cases is uniformly predictable and efficient? In some cases, the returned application has not been matched with the corresponding A-file at the time the applicant is interviewed by USCIS, which causes a delay in adjudication and requires additional effort at the field office level. Would the agency consider establishing a single nationwide procedure to effect this transfer?

Response: Field Operations is developing standardized procedures related to all court filings. However, it will take several months to finalize and implement these processes, as development involves coordination with other agencies and some internal system modifications.

Question 11c: At the present time, members continue to report difficulties in obtaining employment authorization for individuals who are in administratively closed removal proceedings. What is the current policy with respect to those individuals whose applications for cancellation of removal were filed with the Immigration Judge prior to administrative closure? Is this policy the same for individuals who filed or renewed an application for adjustment of status with the Immigration Judge prior to administrative closure?

Response: An applicant who has filed for Cancellation of Removal may be eligible for employment authorization if USCIS finds that the applicant warrants a favorable exercise of discretion on the application for employment authorization and as long as the application for cancellation of removal remains pending ( 8 CFR 274a.12(c)(10)).

An applicant for adjustment of status, whether before USCIS or an Immigration Judge, who has filed for adjustment of status and who USCIS determines warrants a favorable exercise of discretion on the application for employment authorization, is eligible for employment authorization as long as the adjustment application remains pending. (See 8 CFR 274a.12(c)(9)). An individual previously denied adjustment by USCIS may renew their application before an Immigration Judge and apply for an ancillary employment authorization while in removal proceedings.

Administrative closure of immigration proceedings does not result in a final order; it is merely a procedural convenience that authorizes the temporary removal of proceedings from the Court's calendar while retaining the proceedings on the Court's docket. Therefore, during a period of administrative closure, the alien is still "in proceedings" and any application for relief not already adjudicated by the Immigration Judge, remains pending. Therefore, for both Cancellation and Adjustment, where the application is pending at the time of administrative closure, the application remains pending during the administrative closure period and the applicant may be eligible for an ancillary EAD. 


\section{APPENDIX D (continued)}

Question 11d: AILA members also report difficulty where an I-601 is on appeal at the Administrative Appeals Office (AAO) and not in removal. Will the service issue an Employment Authorization Document (EAD) in these circumstances?

Response: A pending Form I-601 does not provide a basis for employment authorization. cf. 8 CFR 274a.12. The concurrently filed Form I-485 may provide a basis for employment authorization only as long as it remains pending. See 8 CFR 274a.12(c)(9)

\section{Matter of Sesay Cases}

In Matter of Sesay, 25 I\&N Dec. 431 (BIA 2011), the Board of Immigration Appeals held that a K-1 fiancé(e) may be granted adjustment of status, even if the marriage to the K-1 petitioner does not exist at the time the adjustment application is adjudicated, if the applicant entered into a bona fide marriage with the K-1 petitioner within 90 days of entering the U.S. on the fiancé(e) visa. In Matter of Le, 25 I\&N Dec. 541 (BIA 2011), the BIA cited Sesay and held that a derivative K-2 child is not ineligible for adjustment of status simply by virtue of having turned 21 after admission to the U.S.

At the AILA/USCIS liaison meetings in October 2011 and March 2012, USCIS indicated that guidance regarding the treatment of cases under Matter of Sesay and Matter of Le was under internal review. ${ }^{21}$ We also discussed several issues relating to cases impacted by Sesay, such as whether an I-864 affidavit of support is required, and whether USCIS would entertain motions to reopen or reconsider for cases erroneously denied either before or after Sesay was issued.

Question 12a: Please advise as to the status of the guidance on Matter of Le and Matter of Sesay. Response: Guidance addressing the decisions in Matter of Sesay and Matter of Le is currently under development.

Question 12b: USCIS has taken the position that following Sesay, if the alien and the K-1 petitioner are divorced, the alien may adjust if the K-1 petitioner has executed or is willing to execute an I-864 affidavit of support. For the reasons set forth in the attached memorandum, we respectfully ask USCIS to reconsider this position, and deem the I-864 affidavit of support an optional method of overcoming the public charge grounds of inadmissibility.

Response: The accompanying memorandum suggests that, in most cases, the K-1 and K-2 will seek adjustment while the marriage is intact, with the Form I-129F petitioner submitting the Form I-864. In cases in which this happens, the later dissolution of the marriage should not have a great impact. As noted in the final rule, dissolution of the marriage does not, itself, affect the Form I-864, with respect to USCIS or a benefit granting agency. The DHS regulation does permit a sponsor to withdraw a Form I864. $8 \mathrm{CFR} \S 213$ a.2(f). But this regulation should properly be read in light of Sesay. Under Sesay, eligibility for a visa number, for adjustment purposes, is determined as of the date of the nonimmigrant admission (assuming a timely marriage). Thus, it is reasonable to conclude that a sponsor's ability to withdraw the Form I-864 is governed by $213 \mathrm{a} .2(\mathrm{f})(1)$, rather than (f)(2). In other words, USCIS believes that, if the I-129F petitioner has submitted a Form I-864, he or she cannot validly withdraw it after the date of the $\mathrm{K}$ nonimmigrant admission.

DHS regulations clearly specify that a $\mathrm{K}$ nonimmigrant's adjustment application must be supported by a valid Form I-864 from the Form I-129F petitioner. $8 \mathrm{CFR} \S 213 \mathrm{a} .2(\mathrm{a})(2)(\mathrm{i})(\mathrm{A})$ and (b)(1). The Attorney General adopted these regulations after conducting the required notice and comment process. See $71 \mathrm{Fed}$.

\footnotetext{
${ }^{21}$ AILA/USCIS Field Operations Liaison Q\&As (3/21/12), published on AILA InfoNet at Doc. No. 12050847 (posted 5/8/12); USCIS/AILA Meeting Minutes (10/15/11), published on AILA InfoNet at Doc. No. 11100570 (posted 10/13/11).
} 


\section{APPENDIX D (continued)}

Reg. 35,732 (2006) (final rule) and $62 \mathrm{Fed}$. Reg. 54,436 (1997) (interim rule). The clarification that the Form I-864 requirement applies to the K-1 and K-2 when they seek to adjust was made in response to a specific comment on this issue. See $71 \mathrm{Fed}$. Reg. at 35,736. As the Board has recognized, administrative agencies do not generally have authority to determine that a regulation is not valid. Cf. Matter of Hernandez-Puente, 20 I\&N Dec. 335, (BIA 1991).

Provided that the K-1 marries the K-1 petitioner as required, an immigrant visa is available to the K-1 (and K-2) for purposes of adjustment. As the Board stressed, the K-1 and K-2 are treated substantially the same as immediate relatives, if, at the time of admission, they were fully eligible for this classification, except that the marriage of the K-1 and K-2 had not yet taken place.

But since they adjust on the same basis as other immediate relatives, INA $\S 212(a)(4)(C)$ expressly says they are inadmissible on public charge grounds unless "the person petitioning for [their] admission" has submitted an affidavit of support under INA 213A. The "person petitioning" is, necessarily, the Form I$129 \mathrm{~F}$ petitioner. USCIS acknowledges that INA $213 \mathrm{~A}(\mathrm{f})$, itself, refers to the petitioner "under 204," which the Form I-129F petitioner is not. If only a $\$ 204$ petitioner can file an I-864, but all immediate relatives (with exceptions not relevant here) need one, then some who are subject to the I-864 requirement will be unable to satisfy it.

Also, treating K-1 and K-2 adjustment applicants as exempt would not be consistent with the main point of Sesay - that they should be treated the same as other immediate relatives, regardless of whether the qualifying marriage takes place before, or very soon after, admission.

Question 12c: Will USCIS adopt a policy and implement procedures to permit late motions to reopen/reconsider without a filing fee for cases that were erroneously denied in light of Sesay? USCIS adopted a similar procedure for certain individuals impacted by the Hootkins v. Napolitano, No. CV-075696 (C.D. Cal. filed Aug. 30, 2007) class action, to address I-130s that were erroneously denied on or after August 30, 2001, due to the death of the petitioning spouse. ${ }^{22}$ USCIS set up a process whereby parties were permitted to request reopening, without having to pay the motion to reopen filing fee. ${ }^{23}$ Such a policy would allow Sesay applicants that were wrongfully denied adjustment of status to avoid the undue expense of refiling and would be a simple means of offering an equitable solution to this group of applicants.

Response: Any application or petition that was erroneously denied will be reconsidered upon timely filing with fee of a motion. See $8 \mathrm{CFR} \S 103.5(\mathrm{a})$. Untimely filed motions alleging service error may be considered for service motion on a case-by-case basis. USCIS is not currently contemplating a blanket procedure to waive the filing requirements of a motion specific to the issues addressed in Mater of Sesay.

\footnotetext{
${ }^{22}$ See Fact Sheet: USCIS to Process Applications of Widow(er)s of Deceased U.S. Citizens, located at: http:/www.uscis.gov/portal/site/uscis/menuitem.5af9bb95919f35e66f614176543f6dla/?vgnextoid=a5febebf59d852

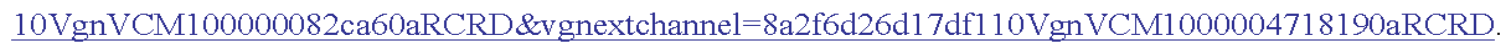

${ }^{23} \mathrm{Id}$.
} 


\section{Appendix E (for summary see page 1834)}

\section{Questions and Answers}

U.S. Department of Homeland Security U.S. Citizenship and Immigration Services Customer Service and Public Engagement Directorate

Washington. DC 20529

\section{U.S. Citizenship} and Immigration Services

\section{USCIS Field Operations - American Immigration Lawyers Association (AILA) Meeting \\ October 4, 2012}

\section{Overview}

On October 4, 2012, the USCIS Field Operations Division hosted an engagement with AILA representatives. USCIS discussed issues related to biometrics collection, NSEERS registration, customer service, as well as other issues. The information below provides a review of the questions solicited by AILA and the responses provided by USCIS.

\section{Issuing NTAs in NSEERS Cases}

Question 1: At the March 21, 2012 meeting, we discussed the issue of NTA issuance as it pertains to a finding of an NSEERS violation (AILA Doc. No. 12050847). USCIS indicated that guidance was forthcoming, and on April 16, 2012, DHS issued new guidance pertaining to the treatment of individuals who were previously subject to NSEERS (AILA Doc. 12042661). The guidance defines willful noncompliance and encourages officers to review the totality of the circumstances when adjudicating a case with a potential NSEERS failure to register issue. The memo further states that "[w]ithin sixty 60 days, components shall issue specific guidance consistent with this policy, ensuring that sufficient procedures are in place and that appropriate training and instruction is provided to ensure compliance of all personnel with this policy." AILA members report that local field offices have placed cases involving NSEERS issues on hold and are waiting for additional guidance and instruction from USCIS headquarters.

Please advise on the status of the USCIS guidance as discussed in the Apri1 16, 2012 memorandum, and provide an indication of how soon action will resume on cases that have been placed on hold.

Response: USCIS provided adjudicators with guidance on implementing the Deputy Secretary's April 16,2012 , memorandum. We are working to develop training materials and procedures to ensure these cases are processed in a standardized manner and in accordance with the new policy. 


\section{APPENDIX E (continued)}

NTA Issuance When Denied I-601 Waivers are on Appeal at the AAO

Question 2a: On April 7, 2011, USCIS indicated that NTA requests may be granted while an I-601 waiver remains pending at the AAO (AILA Doc. No. 11040735). Prior to these meeting minutes, some USCIS field offices would hold the NTA request until the Board of Immigration Appeals (BIA) issued a decision on the I-601 appeal. What guidance has been provided to field offices on the issuance of NTAs under these circumstances?

Response: USCIS assumes that the reference to the Board was intended to be a reference to the Administrative Appeals Office (AAO). USCIS is in the process of issuing a Policy Manual which contains a General Waiver section covering this topic.

Question 2b: If an NTA request is submitted after the appeal and the A-file has already been sent to the $\mathrm{AAO}$, is there a mechanism for field offices to easily retrieve the A-file from the AAO so that the NTA can be issued?

Response: USCIS is generally going to issue an NTA prior to sending a file to the AAO. Internal USCIS file movement is covered in the USCIS Records Handbook. As noted in the Q\&A from the April 7,2011 , engagement, the pendency of an appeal at the AAO does not deprive the immigration judge of jurisdiction to grant a waiver, in conjunction with an adjustment application. 8 CFR 1240.11(a)(2).

K-1/K-2 Adjudications Pursuant to Matter of Sesay/Matter of Le

Question 3: At the March 21, 2012 liaison meeting USCIS stated that guidance would be issued to field offices regarding the adjudication of K-1/K-2 petitions in light of the Board of Immigration Appeals (BIA) holdings in Matter of Sesay, 25 I\&N Dec. 431 (BIA 2011) \& Matter of Le, 25 I\&N Dec. 541 (BIA 2011) (AILA Doc. No. 12050847). Please advise on the current status of the referenced guidance.

Response: This guidance is undergoing the internal review process.

Request for Evidence (RFE), Notice of Intent to Deny (NOID), and Denial of Petition or Application USCIS may issue an RFE, NOID, or denial on an application or petition if the applicant or petitioner fails to submit required initial evidence or fails to submit evidence which establishes eligibility for a benefit. Though the regulations do not articulate the circumstances when an RFE, NOID, or denial should be issued, the Adjudicator's Field Manual (AFM) provides some guidance on when such actions should be taken.

Question 4a: The AFM states that RFEs should be issued when initial required evidence is missing or when additional evidence is needed to adjudicate the application/petition. An RFE should only be issued after USCIS thoroughly conducts an initial review of the application/petition and the information cannot be found through USCIS's resources. RFEs should be narrowly tailored to request the missing evidence necessary to render a decision in the case.

AILA has received reports from members whose cases have been denied after new eligibility issues are raised following an RFE response. RFE example: An I-751 petition is filed with a bona fide marriage exemption waiver request. During the interview, USCIS issues an RFE asking for a copy of the divorce decree because it was not submitted with the original petition. The self-petitioner submits a copy of the divorce decree in response to the RFE, but then receives a denial of the I-751 because he did not submit enough evidence showing the existence of a bona fide relationship.

In this example, the RFE properly requested evidence that was missing from the record. However, the USCIS adjudicator never indicated that there were additional issues and never gave the self-petitioner the opportunity to provide more documentation evidencing a bona fide marriage. 


\section{APPEndix E (continued)}

Would Field Operations remind examiners that where additional eligibility issues arise after a response to an $\mathrm{RFE}$ is received, the petitioner/applicant should be afforded the opportunity to respond to the new allegations before a decision to deny is made?

Response: An applicant or petitioner must establish that he or she is eligible for a requested benefit at the time of filing, but where an adjudicator provides an applicant or petitioner a subsequent opportunity to submit initial or additional evidence of eligibility, Field Operations will remind them that they should endeavor to put the applicant or petitioner on notice of all deficiencies via one RFE.

Question 4b: USCIS adjudicators have the option of denying a case if the initial requested evidence has not been submitted or does not establish eligibility. However, the AFM urges USCIS adjudicators to issue an RFE or NOID instead of denying an application or petition without giving the applicant/petitioner the opportunity to submit the missing evidence or rebut the derogatory evidence. Based on this, an RFE should be issued when there is missing evidence, while a NOID should be issued if there is evidence in the record that shows ineligibility for the requested benefit, or USCIS is aware of derogatory evidence, but the applicant/petitioner is not aware of such evidence.

RFE vs. Denial Example: An N-400 applicant resides outside the U.S. for one year during the continuous residence period. The $\mathrm{N}-400$ is denied without issuing an RFE despite the fact that based on statements made by the applicant at the interview, he may qualify for an exemption of the continuous residence/physical presence requirements under INA $\S \S 316(\mathrm{~b})$-(c).

Given that the applicant was never given the opportunity to provide evidence to show that he qualified for the exemption, please confirm that in this situation, an RFE should generally be issued rather than a denial.

Response: It is the applicant or petitioner's responsibility to establish eligibility at the time of filing, however, in this situation an applicant is generally provided a subsequent opportunity to submit the requisite information.

Question 4c: NOID v. Denial Example: The date of entry into the U.S. provided by an I-485 adjustment of status applicant was inconsistent with the date that the USCIS adjudicator found in the USCIS computer system. Instead of issuing a NOID and giving the applicant the opportunity to rebut the contradictory evidence, USCIS denied the application.

Please confirm that in this situation, a NOID is warranted to allow the applicant the opportunity to rebut the derogatory evidence, rather than a denial.

Response: Based on the facts presented above, a NOID would be warranted in this situation.

Question 4d: Chapter 10.3(f) of the AFM instructs that when a NOID is issued, "applicants or petitioners may choose to respond in writing or ask to inspect the record of proceedings prior to submission of a rebuttal." If an applicant/petitioner asks to inspect the record of proceedings, what actual documents will USCIS permit the applicant/petitioner to inspect?

Response: To inspect the record of proceedings, the applicant must file a Freedom of Information Act (FOIA) request. Applicants will be allowed to inspect all documents unless exempt from release in whole or in part by law.

\section{G-28s Submitted to the USCIS Field Office at an Interview}

Question 5: AILA continues to receive reports from attorneys who are not recognized as the attorney of record notwithstanding the fact that a G-28 has been filed with USCIS. When an attorney submits a Form G-28 during an interview at a USCIS field office, will the G-28 be entered into a USCIS database so that it is electronically available to all USCIS personnel? If not, is there a way to make this process possible? If this is not possible, how will USCIS know that there is an attorney of record who needs to be notified 


\section{APPENDIX E (continued)}

of actions/decisions in the case?

Response: Yes, when an attorney or authorized representative submits a Form G-28 during an interview it should be entered into USCIS systems. A copy of the G-28 will also be placed in the file. If an attorney is not receiving notices and other documentation from USCIS, please bring it to the Field Office director's attention.

\section{Recording of Interviews at USCIS Field Offices \\ During the AILA USCIS Field Operations meeting on March 21, 2012, the issue of USCIS policy regarding the recording of interviews was discussed (AILA Doc. No. 12050847). USCIS stated that it was reviewing guidance on when interviews should be recorded. AILA was pleased to see a brief statement that offices should be equipped with video or audio taping devices, and that if such equipment was not available, arrangements should be made to record difficult cases in the Policy Memorandum of May 23, 2012, which amended pertinent parts of AFM Chapters 12 and 15, (AILA Doc. No. 12052940).}

Question 6a: Please advise as to whether additional guidance on the recording of interviews will be issued. If so, what is the current status of such guidance?

Response: This guidance is undergoing the internal review process.

Question 6b: Is there a plan in place to ensure that all offices have the capacity to record interviews? Response: No, internal discussions are being held to determine whether all offices will have recording capacity and which interviews will be recorded.

Question 6c: Are any districts recording interviews at this time? If so, please advise which offices are recording interviews and under what circumstances the recordings are being conducted.

Response: Some offices do record interviews. Which interviews are recorded varies depending on the office and the circumstances of the particular case.

\section{Biometrics Processing-General Questions/Applicants Not in Proceedings \\ AILA members report that biometrics appointment scheduling can take more than four months when a case that has been held for visa availability at a district office or service center becomes current after a visa backlog. This delay causes undue hardship to such applicants who in many cases have already waited years for their visa numbers to become current. \\ Question 7a: What is the local office process for scheduling biometrics appointments, including renewing biometrics after they expire? Is the process the same at all district offices? \\ Response: At a field office, when a continued case is called up for review and the biometrics have expired, USCIS will re-schedule the applicant with the next available ASC appointment. Family based visa regressed cases are held at the National Benefits Center (NBC) until the visa becomes current. The NBC checks monthly to see if the biometrics have expired on any cases. If the NBC identifies some cases with expired biometrics, they report their findings to Headquarters for scheduling at the ASC closest to the applicant.}

Question 7b: Are district offices expected to generate biometrics appointments within a certain period of time?

Response: There is no specific time requirement to generate a new biometrics appointment.

Question 7c: Can biometrics appointments be expedited, especially when a case has been pending for years due to retrogression?

Response: Yes, an expedite request can be made. The ASC manager considers requests for expedited biometrics capture on a case-by-case basis. 


\section{APPEndix E (continued)}

\section{Biometrics Processing-Applicants in Proceedings}

AILA members continue to report difficulty scheduling biometrics for certain cases in proceedings. Due to court backlogs, it is not unusual for a final merits hearing to be scheduled several years after the master hearing at which the application for relief is filed. By this time, the original biometrics have expired, and the alien is required to have them taken again before the final hearing. In such cases, attorneys report a number of problems, including:

- Lack of communication about when new biometrics are needed;

- Long delays of several months before biometrics appointments are scheduled; and

- Difficulties scheduling new biometrics appointments.

When such problems occur, attorneys often need to involve the local ICE Office of Chief Counsel (ICEOCC) or risk abandonment of the application for relief. Sometimes ICE-OCC is able to run the biometrics again or to request an appointment for the alien at the local ASC. In other cases, ICE-OCC refuses to assist, saying it is a USCIS problem beyond their control.

Question 8a: Please describe the procedure for scheduling biometrics appointments for applicants in proceedings. What role does the local ICE-OCC play? What role does the service center play? What role does the local USCIS field office play? Is the procedure the same nationwide or does it vary by district office?

Question 8b: Upon request from a local ICE-OCC, may an ASC schedule a biometrics appointment for an alien in proceedings whose original biometrics have expired?

Question 8c: What role is played by district and field offices in troubleshooting biometrics scheduling problems, both for aliens in proceedings and those not in proceedings?

Response: Field Operations is unable to respond to these questions as biometrics scheduling for individuals in proceedings is done by the Texas Service Center. Service Center Operations would be in a better position to respond to these questions.

Regarding question $8 \mathrm{c}$, for applicants not in removal proceedings, Field Offices will reach out to the Application Support Center (ASC) for resolution with biometrics scheduling problems.

\section{Stakeholder/Customer Service-Filing Issues at Local Offices}

Question 9a: Local USCIS offices operate under different hours and follow different procedures. Some local USCIS offices only accept filings, such as responses to NOIDS and RFEs, during certain hours. This causes confusion and can result in persons missing their filing deadline. Given the harsh consequences of missing a filing deadline, would USCIS consider creating a drop box system with a date stamp at local offices so that filings may be submitted, even after office hours?

Response: Thank you for this suggestion. We will review it; however, this proposal could be problematic in some offices due to building access restrictions, particularly after hours.

Question 9b: Would USCIS consider instructing all local USCIS offices to allow the filing of papers during regular office hours without restriction?

Response: We will discuss this proposal with Field Operations leadership.

Question 9c: Establishing a policy requiring local offices to provide 30 day notice to the community if office hours change?

Response: Field Operations will take this suggestion under consideration. We are also redesigning our public web pages, and when the new pages are posted online, they will contain real-time information about the hours and status of office openings. 


\section{APPENDIx E (continued)}

Expedited Advance Parole

AILA seeks clarification regarding expedite requests for advance parole. To request expedited advance parole, USCIS provides several options:

(1) Call NCSC and place a service request;

(2) Schedule an InfoPass appointment; or

(3) Write a letter to the local office or service center.

Question 10a: Does USCIS prefer one method over the others when considering a request for emergency/expedited advance parole?

Response: For emergency advance parole, the applicant will need to visit a Field Office. The applicant should make an InfoPass appointment; however, if it is an urgent situation, the office should allow for a walk-in appointment. Applicants must bring evidence supporting the need for issuance of an emergency advance parole document. For an expedite request, calling the NCSC or writing the National Benefits Center (NBC) or Service Center where the Form I-131 is pending are both viable options. Keep in mind, however, that if the applicant contacts the NCSC, the NBC or Service Center will frequently request evidence of the need to expedite the application. If submitting the expedite request in writing, the evidence should accompany the request.

Question 10b: For requests made through the National Customer Service Center (NCSC) or via mail, is there a mechanism in place so that attorneys and/or clients can track the expedite request?

Response: When contacting the NCSC to expedite an application, a service request will be taken and a number will be assigned to this request. To track the status of that request, the attorney or applicant may contact the NCSC again for an update. There are no tracking mechanisms for written expedite requests.

Question 10c: In many cases, USCIS sends the denial letter only to the applicant. Will USCIS also provide notification of the expedite request to the G-28 attorney of record?

Response: Attorneys should also receive notification of the expedite decision.

Question 10di: For expedite requests made at a local office through the InfoPass system: Are all field offices equipped to adjudicate and issue advance parole documents?

Response: Yes.

Question 10dii: If not, please provide a list of offices that may accept emergency advance parole requests via InfoPass.

Response: Not applicable.

Question 10e: Where USCIS denies a request to expedite advance parole, but circumstances change within 30 days, how should the attorney renew the expedite request? For example, a request is made to visit an ill family member, but shortly after the expedite request is denied, the family member dies. Response: The attorney or applicant will need to submit a new expedite request.

\section{Adjustment of Status Following Termination of Conditional Residence}

AILA recently received reports that some field offices were erroneously taking the position that the failure to file a timely I-751 does not result in automatic termination of conditional resident (CR) status, and that the alien continues to hold CR status until it is terminated by an immigration judge. Following this reasoning, USCIS was taking the following steps in cases where the alien obtained CR status, failed to timely file an I-751, and then filed a subsequent I-130/I-485 based on a new marriage:

- Where the subsequent I-130/I-485 was approved, USCIS rescinded the I-485, reinstated CR status based on the original I-485, and in at least some cases, issued a notice to appear (NTA); 


\section{APPENDIX E (continued)}

- Where the subsequent I-130/I-485 was pending, USCIS denied the I-485, administratively closed the I-130, reinstated CR status based on the original I-130/I-485, and in at least some cases, issued an NTA;

Under $8 \mathrm{CFR} \$ 245.1(\mathrm{c})(5)$, an "alien who is already admitted to the United States for permanent residence on a conditional basis" is not eligible for adjustment of status under INA $\$ 245$. Conditional resident status automatically terminates under INA $\$ 216(\mathrm{c})(2)(\mathrm{A})(\mathrm{i})$ if an I-751 petition to remove conditions is not filed within the 90 day period before the second anniversary of the alien's grant of CR status. In Matter of Stockwell, 20 I\&N Dec. 309 (BIA 1991), the BIA held that an alien whose CR status has been terminated is not barred by INA $\$ 245$ (d) from adjusting.

In addition, chapter 25.1 of the USCIS Adjudicator's Field Manual states:

In 1996, the Attorney General proposed an amendment to the regulation, so that a conditional permanent resident would remain ineligible for adjustment of status even after termination of conditional LPR status. 61 Fed. Reg. 43028 (1996). Until the Department of Homeland Security publishes a final rule, and the final rule enters into force, however, USCIS officers are bound to follow Matter of Stockwell.

Therefore, it is clear that upon termination of CPR status, the alien is eligible for adjustment of status. There is no requirement in the statute, the regulations, or Matter of Stockwell that the immigration judge assume jurisdiction over the case for any reason.

Question 11a: We understand that at least one office has since acknowledged that the refusal to adjudicate and administratively close such cases, as described in the second bullet point above, was incorrect. However, it is reported that this office is now refusing to adjudicate these I-130s without an order from the immigration judge that specifically states that conditional resident status is terminated (i.e., an order terminating proceedings is not sufficient). Since conditional resident status automatically terminates under INA $\$ 216(\mathrm{c})(2)(\mathrm{A})(\mathrm{i})$ if an I-751 is not timely filed, please confirm that an IJ order as described above is not required, and that the I-130 should be immediately adjudicated.

Question $11 \mathrm{~b}$ : We have also been advised that the actions described above were taken in response to an internal USCIS memorandum. If this is accurate, would USCIS Field Operations please provide AILA with a copy of this memorandum? Also, would USCIS please issue clarifying guidance to the field on automatic termination of conditional residence in order to ensure that field offices adjudicate these cases moving forward?

Question 11c: Similarly, we have received reports that at least one field office is taking the position that the former conditional resident whose status has terminated is ineligible to adjust unless he or she completes Form I-407, Abandonment of Lawful Permanent Resident Status. Given that CR status terminates automatically upon failure to file a timely I-751 under INA $\$ 216$ (c)(2)(A)(i), we ask USCIS Field Operations to instruct the field that the completion of a Form I-407 in this situation is not required.

Response: As to question $11 \mathrm{a}$, an alien's ability or inability to seek permanent residence is not an issue in a Form I-130 proceeding. Matter of O, 8 I\&N Dec. 295 (BIA 1959). USCIS agrees, therefore, that a Form I-130 should be adjudicated on the merits, rather than "administratively closed," regardless of whether the beneficiary's conditional LPR status has, or has not, been terminated.

Nor is it "clear" that Matter of Stockwell establishes that an IJ proceeding is unnecessary where USCIS has terminated conditional LPR status. In point of fact, the respondent in Matter of Stockwell sought and obtained adjustment only after the immigration judge had sustained the charge of deportability, and had found that the respondent was not eligible for a hardship waiver. 20 I\&N Dec. at 310. 


\section{Appendix E (continued)}

Beyond those observations, USCIS notes that there are numerous scenarios/examples cited without the identification of the specific field office(s) or individual case number(s). We recommend that you bring the individual case(s) and/or issues to the attention of your local USCIS Field Office Director.

\section{Communication with Field Offices}

Question 12a: Please provide a current list of all District Directors and Regional Directors with contact information.

Response: Please see attached.

Question 12b: Please provide an updated organizational chart for the USCIS Field Operations Directorate.

Response: Please see attached. 


\section{APPENDIX F (for summary see page 1834)}

EMPLOYMENT AND TRAINING ADMINISTRATION

ADVISORY SYSTEM

U.S. DEPARTMENT OF LABOR

Washington, D.C. 20210

CLASSIFICATION

OWI/Wagner-Peyser

CORRESPONDENCE SYMBOL

OWI

DATE

October 24, 2012

ADVISORY: TRAINING AND EMPLOYMENT GUIDANCE LETTER NO. 9-12

TO:
ALL STATE WORKFORCE LIAISONS
ALL STATE WORKFORCE AGENCIES
ALL STATE WORKER ADJUSTMENT LIAISONS
ALL AMERICAN JOB CENTER SYSTEM LEADS
WORKFORCE INVESTMENT ACT SECTION 166 INDIAN AND
NATIVE AMERICAN GRANTEES

FROM:

Jane Oates
Assistant Secretary

SUBJECT: $\quad$ Human Trafficking: The Role of the Public Workforce System in the Delivery of Services and Referrals to Victims of Trafficking

1. Purpose. To provide further information to the workforce investment system about the importance of providing workforce, training, and referral services to victims of human trafficking and to give updated guidance on how to deliver these services under the Workforce Investment Act of 1998 (WIA), the Trafficking Victims Protection Act of 2000 (TVPA) and the Trafficking Victims Protection Reauthorization Acts of 2003, 2005 and 2008 (TVPRA).

2. References. The Victims of Trafficking and Violence Protection Act of 2000 (Public Law 106-386) (containing the Trafficking Victims Protection Act of 2000 (TVPA)); the Trafficking Victims Protection Reauthorization Act of 2003 (Public Law 108-193) (TVPRA 2003); the Trafficking Victims Protection Reauthorization Act of 2005 (Public Law 109-164) (TVPRA 2005); the William Wilberforce Trafficking Victims Protection Reauthorization Act of 2008 (Public Law 110-457) (TVPRA 2008); the Workforce Investment Act of 1998 (WIA) (Public Law 105-220, 29 U.S.C. 2801, et seq.); WIA Final Rule, 20 C.F.R. parts 652, 660-671 (65 F.R. 49294 (August 11, 2000)); Interim Final Rule implementing the non-discrimination and equal opportunity provision (section 188) of WIA, 29 C.F.R. part 37 (64 F.R. 61692 (November 12, 1999); and the Immigration and Nationality Act (8 U.S.C. 1101-1537); Training and Employment Guidance Letter (TEGL) 19-01; TEGL 19-01 Change 1; TEGL 2602; Training and Employment Notice (TEN) 14-05. 


\section{APPENDIX F (continued)}

$-2-$

3. Background. Trafficking in persons affects millions of individuals worldwide. Individuals may be lured into trafficking networks through false promises of good working conditions and high pay as domestic workers, factory and farm workers, childcare workers, waitstaff, sales clerks, models, or in other occupations. Others are simply kidnapped. Many victims of trafficking may remain undetected because strategies used by the perpetrators isolate victims and prevent them from coming forward. Additionally, many victims of trafficking do not self-identify and may be unaware of resources and services that are available to assist them.

The Department of Labor (DOL) plays a role in the U.S. Government's efforts to combat trafficking in persons, including by identifying and seeking restitution for unpaid labor performed by victims of trafficking; providing training and employment services to victims of trafficking who qualify for those services and helping them to become self-sufficient; funding research and technical assistance to combat the worst forms of child labor overseas; and maintaining lists of goods, including their countries of origin, that are made using forced labor or forced child labor.

4. Definitions. The Trafficking Victims Protection Act (TVPA), Sections 107(b)(1)(A) and (B), requires the Secretary of Labor to provide benefits and services to victims of "severe forms of trafficking in persons" to the same extent as aliens who are admitted to the United States as refugees. Under section 103(8) of the TVPA, the term "severe forms of trafficking in persons" is defined as:

(A) sex trafficking in which a commercial sex act is induced by force, fraud, or coercion, or in which the person induced to perform such act has not attained 18 years of age; or

(B) the recruitment, harboring, transportation, provision, or obtaining of a person for labor or services, through the use of force, fraud, or coercion for the purpose of subjection to involuntary servitude, peonage, debt bondage, or slavery.

5. Trafficking Victim Services and the American Job Centers. The public workforce system plays a key role in providing benefits and services to victims of trafficking. Finding employment is an essential step in integrating victims of trafficking into society and American Job Centers can play a critical role in assisting victims find and prepare for employment.

It is important to note that victims of trafficking may have suffered psychological and often physical trauma. A broad body of literature exists on how to engage with victims of physical or psychological trauma, which is a topic beyond the scope of this guidance letter.

American Job Center staff can assist trafficking victims in the following ways, as applicable:

\section{A. Recognize the characteristics of victims of trafficking and refer individuals to proper authorities and resources.}

Many victims of trafficking do not self-identify. A role for staff at American Job Centers is to recognize the characteristics of potential victims of trafficking and refer them to the proper authorities and resources. For information on how to identify potential victims of trafficking, see Attachment A, "Characteristics of Potential Victims of Trafficking." For information about hotlines that frontline staff can call to 


\section{APPENDIx F (continued)}

$-3-$

get help for potential victims, see Attachment B, "Trafficking Hotlines." If an individual is under immediate threat or states that they are in danger. staff should call $\underline{911}$.

\section{B. Provide employment and training services.}

U.S. citizens or lawful residents who are victims of trafficking can receive the same services at American Job Centers that are provided to the general public under WIA.

In addition, under section 107 (b) of the TVPA, certain foreign nationals are also eligible for WIA Title I services. This includes: (1) victims of a severe form of trafficking in persons, or (2) individuals granted a nonimmigrant " $T$ " visa.

For purposes of being eligible for WIA Title I services as a victim of a severe form of trafficking:

- Individuals 18 years of age or older must have been subjected to an act or practice described in the definition of "severe forms of trafficking in persons" and have received a letter of certification issued by the Department of Health and Human Services. 22 U.S.C. $\$ 7105$ (b)(1).

- Children under 18 years old who have been subjected to a severe form of trafficking need not be certified by HHS to be eligible for services; instead, HHS issues Letters of Eligibility to minor victims of trafficking. As with any participant, they must meet all applicable program eligibility requirements to receive WIA Title I services.

Individuals who are granted T visas from the Department of Homeland Security are also eligible for WIA Title I services. The T nonimmigrant Status ( T visa) is available to individuals who are or have been victims of human trafficking, and protects these victims of human trafficking by allowing them to remain in the United States to assist in an investigation or prosecution of human trafficking. Additional information about $T$ visas and the HHS certification process can be found in TEGL 19-01 Change 1.

Employment and training services should be provided to victims of trafficking to the same extent and following the same procedures and case management processes as for other customers at the American Job Centers. However, in the case of victims of trafficking, services may need to be tailored and adapted to match the particular needs of this population. For instance, victims of trafficking may have Limited English Proficiency (LEP), criminal records (including from being forced into prostitution), or limited resumes.

Victims of trafficking who have LEP will likely require referrals to courses in English as a Second Language (ESL) in order to enhance job readiness. Frontline staff should work with local training providers and community colleges to find ESL course offerings as needed. TEGL 26-02 ("Publication of Revised Guidance Regarding the Title VI Prohibition Against National Origin Discrimination Affecting 


\section{APPENDIX F (continued)}

$-4-$

Limited English Proficient Persons") and TEN 14-05 ("Release of On-Line Training Resources and Census Data on Limited English Proficiency Individuals in Local Workforce Areas and a translatable Glossary of Workforce Terms") provide some resources and guidance on working with LEP persons.

\section{Offer information and referral to other wraparound services and/or law enforcement.}

In most cases, victims of trafficking will approach American Job Centers towards the end of their rehabilitation process and will have already been working with other Federal, state, local or nonprofit organizations and agencies.

In the event that the victim has not yet received services, it is important for American Job Center staff to be aware of and utilize local resources and service providers, particularly non-profit organizations that provide services to trafficking victims. Service providers for trafficking victims can also refer or accompany their clients to the nearest American Job Center when they are ready for employment and training services.

A description of available services for victims of trafficking offered either directly by Federal agencies or provided by local service providers with funding from the U.S. Government can be found in the document "Services Available to Victims of Human Trafficking: A Resource Guide for Social Service Providers" available at: https://www.hsdl.org/?view\&did=706130.

If no local service providers are known, the National Human Trafficking Resource Center (NHTRC) at 1-888-3737-888 can help determine best steps for assisting the individual. See Attachment B, "Trafficking Hotlines," for additional information. Frontline staff may also call the NHTRC ahead of time to inquire about local service providers and familiarize themselves with what is available for victims in the local community.

6. Action Required. State Workforce Agency staff should familiarize themselves with the content of this TEGL and follow the procedures set forth herein for working with trafficked persons. Key frontline staff and American Job Center managers should also plan, where schedules and resources allow, to participate in the forthcoming training Webinar on Trafficking in Persons Awareness. This Webinar will also be recorded and made available online for future use via the Workforce3one Web site (www.workforce3one.org/).

7. Inquiries. Questions should be addressed to the appropriate ETA Regional Office.

\section{Attachments.}

- Attachment A, "Characteristics of Potential Victims of Trafficking."

- Attachment B, "Trafficking Hotlines." 


\section{APPENDIX F (continued)}

Attachment A

\section{Characteristics of Potential Victims of Trafficking}

The information on this page lists some warning signs that trafficking may be taking place. The presence of any of these signs should be taken seriously and may indicate that trafficking is occurring. These warnings signs are based on the Department of Homeland Security's (DHS) Blue Campaign Human Trafficking Indicators card. However, American Job Center staff are not expected to, or may not be able to, identify these signs. More tools and information are available from DHS at: http://www.dhs.gov/human-trafficking-blue-campaign-toolkit.

\section{Warning Signs that Trafficking mav have Occurred:}

- The potential victim does not possess identification and/or travel documents.

- The potential victim appears to be coached on what to say to law enforcement and immigration officials.

- The potential victim was recruited for one purpose and forced to engage in some other job.

- The potential victim's salary appears to be being garnished to pay off a smuggling fee. (Note: Paying off a smuggling fee alone is not considered trafficking.)

- The potential victim appears to have been forced to perform sexual acts.

- The potential victim does not appear to have freedom of movement.

- The potential victim and/or his or her family have been threatened with harm if the victim attempts to escape.

- The potential victim has been threatened with deportation or law enforcement action.

- The potential victim has been harmed or deprived of food, water, sleep, medical care, and/or other life necessities.

- The potential victim cannot freely contact friends or family.

- The potential victim is a juvenile engaged in commercial sex.

- The potential victim is not allowed to socialize or attend religious services. 


\section{APPENDIx F (continued)}

Attachment B

\section{Trafficking Hotlines}

Human Trafficking is a crime involving the exploitation of someone for the purposes of compelled labor or a commercial sex act through the use of force, fraud, or coercion. Where a person younger than 18 is induced to perform a commercial sex act, it is a crime regardless of whether there is any force, fraud, or coercion. Victims can be anyone from around the world or right next door: women and men, adults and children, citizens and noncitizens alike.

\section{$\begin{array}{lll}\text { GET HELP } & \text { REPORT A TIP }\end{array}$}

-- IN AN EMERGENCY, PLEASE CALL 911-

Call the National Human Trafficking Resource Center at 1-888-3737-888 to:

- GET HELP and connect with a service provider in your area;

- REPORT A TIP with information on potential human trafficking activity; or

- LEARN MORE by requesting training, technical assistance, or resources.

The National Human Trafficking Resource Center (NHTRC) is a national, toll-free hotline available to answer calls from anywhere in the country, 24 hours a day, 7 days a week, every day of the year. The NHTRC is not a law enforcement or immigration authority and is operated by a nongovernmental organization funded by the Federal government.

Call federal law enforcement directly to report suspected human trafficking activity and get help:

- U.S. Department of Homeland Security at 1-866-347-2423 24 hours a day, 7 days a week, every day of the year, or submit a tip online at www.ice.gov/tips. Individuals across the world can report suspicious criminal activity to the U.S. Immigration and Customs Enforcement (ICE) Homeland Security Investigations (HSI) Tip Line. The Tip Line is accessible internationally by calling $\underline{1-802-872-}$ 6199. Highly trained specialists take reports from both the public and law enforcement agencies on more than 400 laws enforced by ICE HSI, including those related to human trafficking.

- U.S. Department of Justice Trafficking in Persons and Worker Exploitation Task Force Complaint Line at 1-888-428-7581 (voice and TTY) from 9:00am to 5:00pm (EST). Individuals can report incidents of trafficking to this hotline. You may also submit a tip online to the $\mathrm{FBI}$ at https://tips.fbi.gov, or call your local FBI office (you can get their number at www.fbi.gov/contact-us/field/field-offices.

Call the following federal government lines for other assistance:

- U.S. Department of Labor, Wage and Hour Division at 1-866-4USWAGE (1-866-487-9243) for cases where labor exploitation may be present but does not rise to the threshold of trafficking.

- U.S. Department of Labor OIG Hotline at 1-202-693-6999 or 1-800-347-3756, hotline@oig.dol.gov, or http://www.oig.dol.gov/hotlinemain.htm 24 hours a day, 7 days a week to report allegations of trafficking committed through fraud in DOL programs, including, but not limited to, the $\mathrm{H}-1 \mathrm{~B}, \mathrm{H}-2 \mathrm{~A}$, 


\section{Appendix F (continued)}

Attachment B

$\mathrm{H}-2 \mathrm{~B}$, and PERM. When filing an OIG Hotline complaint, it is not necessary to provide names or any other identifying information.

- Equal Employment Opportunity Commission (EEOC) at 1-800-669-4000 from 7:00am to 8:00pm (EST) for information about how workers, including trafficking victims, can file a charge of employment discrimination.

\section{Report suspected child prostitution activity to the CyberTipline:}

- The National Center for Missing \& Exploited Children, at 1-800-THE-LOST or www.cybertipline.com, 24 hours a day, 7 days a week. The Congressionally-authorized CyberTipline is operated by a nongovernmental organization and provides a means for reporting crimes against children and is staffed 24 hours a day, 7 days a week. 


\title{
APPENDIX G (for summary see page 1834)
}

\author{
UNCLASSIFIED STATE 00101466 \\ VZCZCXYZOOOO \\ RR RUEHWEB \\ DE RUEHC \#1466 2791841 \\ ZNR UUUUU ZZH \\ R 051837 Z OCT 12 \\ EM SECSTATE WASHINGTON DC \\ TO RHMCSUU/DEPT OF HOMEIAND SECURITY WASHINGTON DC \\ R $051837 Z$ OCT 12 \\ EM SECSTATE WASHDC \\ TO ALI DIPLOMATIC AND CONSULAR POSTS COLLECTIVE \\ RUEHKH/AMEMBASSY KHARTOUM OOOO \\ RUEHTU/AMEMBASSY TUNIS OOOO \\ BT \\ UNCLAS STATE 101466 \\ E.O. 13526: N/A \\ TAGS: CVIS \\ SUBJECT: $B-I$ IN LIEU OE H \\ 1. SUMMARY: THIS ALDAC IS BEING REISSUED TO ALI CONSULAR \\ POSTS WITH EDITS TO PARAGRAPHS 4, 7, AND 10 WITH THE \\ ASSISTANCE OF DHS. THESE PARAGRAPHS WERE EDITED IN ORDER TO \\ CLARIFY ACTIVITIES THAT WILL PERMIT A B-1 IN LIEU OF H \\ ANNOTATION. THIS ALDAC SUPERSEDES THE JUNE $21,2012 \mathrm{~B}-1$ IN \\ LIEU OF H ALDAC, 12 STATE 63795. THE B-I IN IIEU OE H-1B AND \\ H-3 GUIDANCE IN \\ 9 FAM 41.31 N11 IS UNDER REVIEW IN AN INTERAGENCY PROCESS, BUT \\ REMAINS IN EFFECT UNTIL FURTHER NOTICE. CONSULAR OFFICERS \\ SHOULD NOT HESITATE TO APPLY THIS GUIDANCE IN APPROPRIATE \\ CASES. THIS CABLE REVIEWS THE EXISTING B-1 IN LIEU OE H-IB \\ AND $\mathrm{H}-3$ GUIDANCE AND PROVIDES ADVICE EOR CONSULAR OFFICERS TO \\ EEFECTIVELY APPIY THIS GUIDANCE. \\ 2. 9 FAM 41.31 N11 STATES, IN PART: "THERE ARE CASES IN WHICH \\ ALIENS WHO QUALIFY FOR H-I OR H-3 VISAS MAY MORE APPROPRIATELY \\ BE CLASSTETED AS B-1 VISA APPLICANTS IN CERTAIN CIRCUMSTANCES; \\ E.G., A QUALIEIED H-I OR H-3 VISA APPLICANT COMING TO THE \\ UNITED STATES TO PEREORM H-1 SERVICES OR TO PARTICIPATE IN A \\ TRAINING PROGRAM. IN SUCH A CASE, THE APPLICANT MUST NOT \\ RECEIVE ANY SALARY OR OTHER REMUNERATION EROM A U.S. SOURCE \\ OTHER THAN AN EXPENSE ALLOWANCE OR OTHER REIMBURSEMENT FOR \\ EXPENSES INCIDENTAL TO THE ALIEN'S TEMPORARY STAY. FOR \\ PURPOSES OF THIS NOTE, IT IS ESSENTIAL THAT THE REMUNERATION \\ OR SOURCE OF INCOME FOR SERVICES PEREORMED IN THE UNITED \\ STATES CONTINUE TO BE PROVIDED BY THE BUSINESS ENTITY IOCATED \\ ABROAD, AND THAT THE ALIEN MEETS THE FOLLOWING CRITERIA:
}

(1) WITH REGARD TO FOREIGN-SOURCED REMUNERATION FOR SERVICES PEREORMED BY ALIENS ADMITTED UNDER THE PROVISIONS OF INA 101 (A) (15) (B), THE DEPARTMENT HAS MAINTAINED THAT WHERE A U.S. BUSINESS ENTERPRISE OR ENTITY HAS A SEPARATE BUSINESS ENTERPRISE ABROAD, THE SALARY PAID BY SUCH FOREIGN ENTITY SHOULD NOT BE CONSIDERED AS COMING FROM A 'U.S. SOURCE;'

(2) IN ORDER EOR AN EMPLOYER TO BE CONSIDERED A 'FOREIGN FIRM' THE ENTITY MUST HAVE AN OFETCE ABROAD AND ITS PAYROLL MUST BE 


\section{APPENDIX G (continued)}

DISBURSED ABROAD. TO QUALIEY FOR A B-I VISA, THE EMPLOYEE MUST CUSTOMARILY BE EMPLOYED BY THE FOREIGN EIRM, THE EMPLOYING ENTITY MUST PAY THE EMPLOYEE'S SALARY, AND THE SOURCE OF THE EMPLOYEE'S SALARY MUST BE ABROAD."

APPLICANT MUST OVERCOME PRESUMPTION OF IMMIGRANT INTENT 'TO QUALIFY FOR B STATUS

3. APPLICANTS FOR ALI B VISAS, INCLUDING B-1 VISAS ISSUED UNDER 9 FAM 41.31 N11 ("NOTE 11 "), MUST OVERCOME THE PRESUMPTION OF' IMMIGRANT INTENT ESTABLISHED BY INA 214 (B). NOTE 11 APPIICANTS MIGHT QUALIFY FOR B, H, AND/OR L VISAS, BUT MAY CHOOSE A B VISA UNDER NOTE 11 FOR CONVENIENCE AND EEEICIENCY.

APPLICANT MUST ALSO PLAN TO ENGAGE IN H ACTIVITY -...- - - - - - - - - - - - - - - - - - - - - - - - - - - - - - -

4. APPLICANTS SHOULD ONLY BE ANNOTATED (SEE PARA 6 BELOW) UNDER B-1 IN LIEU OF H-IB WHEN THEY PLAN TO ENGAGE IN ACTIVITIES 'THAT WOULD NORMALLY REQUIRE AN H-1B. SIMILARIY, APPLICANTS SHOULD ONLY BE ANNOTATED UNDER B-I IN LIEU OE H-3 IN THE RARE CASE WHEN THE PROPOSED TRAINING HAS A PRACTICAI. COMPONENT OR OTHER COMPONENT THAT IS PERMISSIBLE IN H-3 S'TATUS.

EMPLOYER AND SOURCE OF REMUNERATION MUST BE OVERSEAS

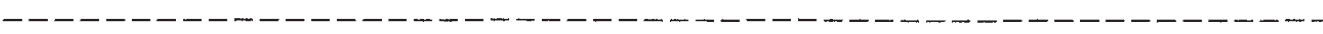

5. AS DESCRIBED IN NOTE 11, THE APPLICANT MUST CONTINUE TO BE PAID BY THE OVERSEAS EMPLOYER WHILE THEY ARE IN THE U.S. AN EXPENSE ATIJOWANCE EROM A U.S. EMPLOYER IS PERMITTED, AND A EOREIGN BRANCH OF A U.S. FIRM CAN QUALIFY AS A FOREIGN EIRM EOR PURPOSES OF NOTE 11.

NOT EOR LONG-TERM PLACEMENT

- - - - - - - - - - - - - - - - - - - - -

6. B VISAS ISSUED UNDER NOTE 11 ARE NOT INTENDED FOR LONG-TERM PLACEMENT AND SHOULD GENERALLY BE ISSUED FOR ACTIVITY IN THE U.S. THAT IS LESS THAN SIX MONTHS IN DURATION. ALSO, TO AVOID POSSIBLE DELAYS AT THE PORT OF ENTRY, THE DEPARTMENT ADVISES CONSULAR OFFICERS TO ANNOTATE WITH "B IN LIEU OF $H, 9$ FAM $41.31 \mathrm{~N} 11 . "$

B-I IN LIEU OF H-IB

7. IN ORDER TO QUALIFY FOR B-I IN LIEU OF H-1B, THE CONSUIAAR OFFICER MUST EIND THAT THE APPLICANT CLEARLY MEETS THE H-IB REQUIREMENTS, AND IS CTEEARLY AN EMPLOYEE OF THE OVERSEAS 


\section{APPENDIX G (continued)}

COMPANY. THE ACTIVITIES AND THE APPLICANT MUST BE H-1B CALIBER, THAT IS, THE ACTIVITIES MUST MEET THE DEFINITION OE "SPECIALTY OCCUPATION" IN THAT IT REQUIRES A BACHELOR'S DEGREE OR EQUIVALENT, AND THE APPLICANT MUST CLEARLY HAVE A BACHELOR'S DEGREE OR EQUIVALENT EXPERIENCE. IF THE H-1B CALIBER OF THE ACTIVITIES CANNOT BE CLEARLY ESTABLISHED TO THE SATISEACTION OE THE CONSULAR OFEICER, THEN THE APPLICANT MUST EILE A PETITION FOR AN H-IB WITH USCIS. EURTHER, THE APPLICANT MUST CLEARLY BE AN EMPLOYEE OF THE OVERSEAS FIRM, AND PAID BY THE OVERSEAS FIRM. IT MAY BE MORE DIFEICULT FOR A NEW HIRE TO ESTABIISH THEIR EMPLOYMENT STATUS WITH THE OVERSEAS FIRM IF THEY ARE IMMEDIATELY SENT TO THE U.S. TO ENGAGE IN H-IB CALIBER ACTIVITY.

8. THUS, IN ORDER TO QUALIEY FOR B-1 IN LIEU OF H-1B, THE APPLICANT MUST OVERCOME THE 214 (B) PRESUMPTION OF IMMIGRANT INTENT, CLEARLY BE EMPLOYED AND PAID BY AN OVERSEAS FIRM, AND CLEARLY PLAN TO ENGAGE IN H-1B CALIBER ACTIVITY FOR A TEMPORARY PERIOD, NORMALLY LESS THAN SIX MONTHS IN DURATION. NOTE THAT WHILE AN H-IB WORKER IS NOT SUBJECT TO THE IMMIGRANT INTENT PROVISIONS OF 214 (B) AND MAY CHANGE EMPLOYERS IN THE U.S., A NOTE 11 B-1 APPIICANT IS SUBJECT TO 214 (B) AND MUST INTEND TO MAINTAIN EMPLOYMENT WITH THE SAME OVERSEAS EMPLOYER.

9. EXAMPLES OF APPLICANTS WHO WOULD NEED TO FILE AN H-1B ARE THOSE WHO: ARE NOT CIEARIY H-1B CALIBER OR ARE NOT PLANNING TO ENGAGE IN H-IB CALIBER ACTIVITY; ARE NOT CLEARLY AN EMPLOYEE OF AN OVERSEAS FIRM OR PAID BY AN OVERSEAS FIRM; PLAN TO STAY IN THE U.S. ON MORE THAN A TEMPORARY, SHORT-TERM BASIS (WHICH GENERALLY WOULD MEAN A STAY OF LESS THAN SIX MONTHS); PLAN TO CHANGE EMPLOYERS IN THE U.S.; OR FAIL TO OVERCOME $214(\mathrm{~B})$.

B-I IN LIEU OF $\mathrm{H}-3$

B- - - - - - - - -

10. IN ORDER TO QUALIEY EOR B-1 IN LIEU OF H-3, THE CONSULAR OFEICER MUST FIND THAT THE APPIICANT CLEARLY MEETS THE H-3 REQUIREMENTS FOR A TRAINEE, AND IS CLEARLY AN EMPLOYEE OF THE OVERSEAS COMPANY. A TRAINING PROGRAM DESIGNED TO TRAIN AIIENS TO WORK IN THE U.S. IS NOT AN APPROPRIATE H-3 TRAINING PROGRAM. THE REGULATORY CRITERIA EOR AN H-3 PETITION APPROVAL CAN BE FOUND AT 9 EAM 41.53 N4.5-1. FURTHER, THE APPIICANT MUST BE ABLE TO DESCRIBE THE TRAINING, AND THE CONSULAR OFFICER NORMALIY WTLL REQUIRE DOCUMENTATION OF THE TRAINING PROVIDED BY THE EMPLOYER. IF THE APPLICANT CANNOT CLEAREY ESTABLISH THESE REQUIREMENTS, THEN THEY MUST FILE AN H-3 PETITION WITH USCIS.

11. THUS, IN ORDER TO QUALIFY FOR B-1 IN LIEU OF H-3, THE APPLICANT MUST OVERCOME THE 214 (B) PRESUMPTION OF IMMIGRANT INTENT, CLEARLY BE, EMPLOYED AND PAID BY AN OVERSEAS EIRM, AND CLEARLY PLAN TO ENGAGE IN H-3 ACTIVITY AS DESCRIBED ABOVE, GENERALLY FOR LESS THAN SIX MONTHS.

\section{MINIMIZE CONSIDERED.}




\section{APPENDIX G (continued)}

CLINTON

BT

\#1 466

UNCLASSIFIED STATE 00101466 


\section{SERVICE QUESTIONS?}

If you have any questions about the status of your subscription, please contact your Matthew Bender representative, or call our Customer Service line at:

1-800-833-9844

(e-mail: customer.support@lexisnexis.com)

\section{BENDER'S IMMIGRATION BULLETIN:}

Partner of Charles Gordon, Stanley Mailman, Stephen Yale-Loehr, and Ronald Y. Wada's Immigration Law and Procedure

Call your local LexisNexis representative (or 1-800-223-1940 or 1-800-424-4200) for pricing. 


\section{Global Business Immigration Practice Guide}

Alliance of Business Immigration Lawyers (ABIL);

Stephen Yale-Loehr, General Editor

\section{$A B I C$}

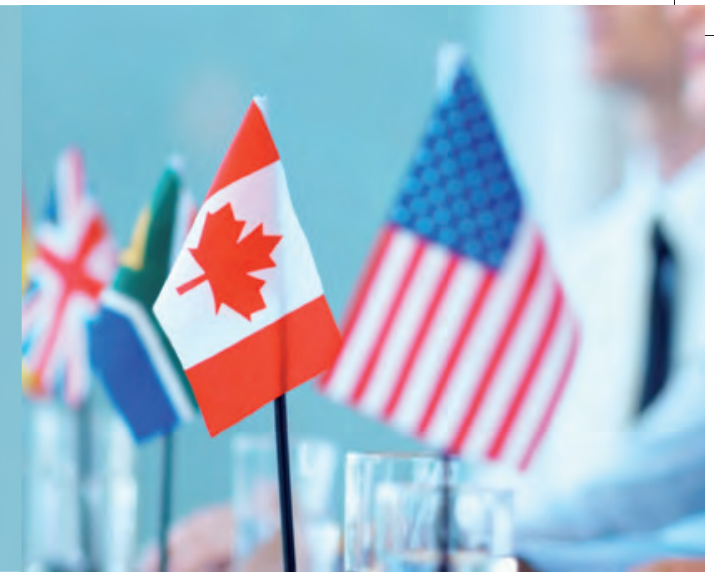

This new Practice Guide is a one-stop resource for dealing with questions related to business immigration issues in immigration hotspots around the world. Written and edited by a global team of expert attorney-members of the ABIL, this comprehensive guide is designed to be used by:

- Human resources professionals and in-house attorneys who need to instruct, understand, and liaise with immigration lawyers licensed in other countries

- Business immigration attorneys who regularly work with multinational corporations and their employees and HR professionals

- Attorneys interested in expanding their practice to include global business immigration services

\section{This publication provides:}

- An overview of the immigration law requirements and procedures for over twenty countries

- Practical information and tips for obtaining visas, work permits, resident status, naturalization, and other nonimmigrant and immigrant pathways to conducting business, investing, and working in those countries

- A general overview of the appropriate options for a particular employee

- Information on how an employee can obtain and maintain authorization to work in a target country

Chapters are organized uniformly, making it easy to compare practices and procedures from country to country. Useful links to additional resources and forms are included. The expertise of ABIL's attorney-members across the globe serve as an ideal starting point in your research into global business immigration issues.

\section{Countries covered include:}

$\begin{array}{lll}\text { - Australia } & \text { - France } & \text { - Mexico } \\ \text { - Belgium } & \text { - Germany } & \text { - Russia } \\ \text { - Brazil } & \text { - Hong Kong } & \text { - Spain } \\ \text { - Canada } & \text { - India } & \text { - Switzerland } \\ \text { - China } & \text { - Ireland } & \text { - Turkey } \\ \text { - Costa Rica } & \text { - Italy } & \text { - UK } \\ \text { - European Union } & \text { - Japan } & \text { - United States }\end{array}$

\section{Global Business Immigration Practice Guide}

\$259 | 1 volume, softbound, Pub. \#01713, ISBN 9781422496541 . elSBN 9780327173878 Price does not include sales tax, shipping or handling. Price subject to change without notice.

\section{ORDER TODAY!}

CALL toll-free 800.223.1940

VISIT www.lexisnexis.com/abil

CONTACT your LexisNexis ${ }^{\circledR}$ sales representative International Orders

Email nicole.hahn@lexisnexis.com I Call 00 +1+518.487.3004

\author{
Contributing Authors

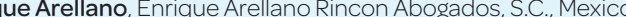 \\ Timur Bne Bart, Jacqueline Bart \& Associates, Canada \\ Ursina Brack, VISCHER Ltd., Switzerland \\ Bernard Caris, Liedekerke Wolters Waelbroeck Kirkpatrick, Beloium \\ Maria Lianides Celebi, Bener Law Office, Turkey \\ Zhu (June) Cheng, Fredrikson \& Byron, Minneapolis, MN \\ Eugene Chow, Chow King \& Associates, China \\ Steven A. Clark, Flynn \& Clark, P.C., Cambridge, MA \\ 政, \\ Laura Devine, Laura Devine Solicitors, UK \\ Mareza I. Estevez, Cognizant Technology Solutions, NJ \\ Rami Fakhoury, Fakhoury Law Group, P.C., Troy, M! \\ Immigration Law Group, Los Angeles, CA \\ Avyan Funai, Masuda Funai, Chicago, IL \\ Avi Gomberg, Gomberg Dalfen, Canada \\ Urs Haegi, VISCHER Ltd., Switzerland \\ Kenneth Ing Porta Immigration, Canada \\ Jelle Kroes, Kroes Advocaten Immigration Lawyers, Netherlands \\ Mark Levey, Fakhoury Law Group, Troy, MI \\ Daniela Lima, EMDOC, Brazil \\ harte, Garfinkel Immigration Law Firm, Charlotte, NC \\ ciates, San Frar \\ Ramya Mahesh, Little \& Co., India \\ Katie Malyon, Katie Malyon \& Associates, Lawyers, Australia \\ Gunther Mävers, Mütze Korsch Rechtsanwaltsgesellschaft mbH, Germany \\ Dehta, Cyrus D. Mehta \& Associates, New York, NY \\ Restecky, AURORA Translation \& Legal Services, Japan \\ Lisa Middlemiss, Gomberg Dalfen, Canada \\ Sarah E. Murphy, Serotte, Reich \& Wilson, LLP, Buffalo, NY \\ Angelo Paparelli, Seyfarth Shaw LLP, Los Angeles, CA \\ 政, Jr, Deloitte LLP, New York, NY \\ Aki Tanaka, Kitahama Partners, Japan \\ Karl Waheed, Karl Waheed Avocats, France \\ Bernard P. Wolfsdorf, Wolfsdorf Immigration Law Group, Los Angeles, CA \\ Paul J. Zambie, FosterQuan, Austin, TX \\ Brian D. Zuccaro, Serotte Reich \& Wilson, LLP, Buffalo, NY
}

\section{- LexisNexis}

